\title{
The CAMS interim Reanalysis of Carbon Monoxide, Ozone and Aerosol for 2003-2015
}

\author{
Johannes Flemming ${ }^{1}$, Angela Benedetti ${ }^{1}$, Antje Inness ${ }^{1}$, Richard J. Engelen ${ }^{1}$, Luke Jones ${ }^{1}$, Vincent Huijnen ${ }^{2}$, \\ Samuel Remy $^{3}$, Mark Parrington ${ }^{1}$, Martin Suttie ${ }^{1}$, Alessio Bozzo ${ }^{1}$, Vincent-Henri Peuch ${ }^{1}$, Dimitris Akritidis ${ }^{4}$, and \\ Eleni Katragkou ${ }^{4}$ \\ ${ }^{1}$ European Centre for Medium-Range Weather Forecasts, Reading, UK \\ ${ }^{2}$ Royal Netherlands Meteorological Institute, De Bilt, the Netherlands \\ ${ }^{3}$ Laboratoire de météorologie dynamique, UPMC/CNRS, Paris, France \\ ${ }^{4}$ Department of Meteorology and Climatology, Aristotle University of Thessaloniki, School of Geology, \\ Thessaloniki, Greece
}

Correspondence to: Johannes Flemming (johannes.flemming@ecmwf.int)

Received: 22 July 2016 - Discussion started: 26 August 2016

Revised: 19 December 2016 - Accepted: 7 January 2017 - Published: 9 February 2017

\begin{abstract}
A new global reanalysis data set of atmospheric composition (AC) for the period 2003-2015 has been produced by the Copernicus Atmosphere Monitoring Service (CAMS). Satellite observations of total column (TC) carbon monoxide (CO) and aerosol optical depth (AOD), as well as several TC and profile observations of ozone, have been assimilated with the Integrated Forecasting System for Composition (C-IFS) of the European Centre for Medium-Range Weather Forecasting. Compared to the previous Monitoring Atmospheric Composition and Climate (MACC) reanalysis (MACCRA), the new CAMS interim reanalysis (CAMSiRA) is of a coarser horizontal resolution of about $110 \mathrm{~km}$, compared to $80 \mathrm{~km}$, but covers a longer period with the intent to be continued to present day. This paper compares CAMSiRA with MACCRA and a control run experiment (CR) without assimilation of AC retrievals. CAMSiRA has smaller biases than the $\mathrm{CR}$ with respect to independent observations of $\mathrm{CO}$, AOD and stratospheric ozone. However, ozone at the surface could not be improved by the assimilation because of the strong impact of surface processes such as dry deposition and titration with nitrogen monoxide (NO), which were both unchanged by the assimilation. The assimilation of AOD led to a global reduction of sea salt and desert dust as well as an exaggerated increase in sulfate. Compared to MACCRA, CAMSiRA had smaller biases for AOD, surface CO and TC ozone as well as for upper stratospheric and tropospheric ozone. Finally, the temporal consistency of CAMSiRA was
\end{abstract}

better than the one of MACCRA. This was achieved by using a revised emission data set as well as by applying careful selection and bias correction to the assimilated retrievals. CAMSiRA is therefore better suited than MACCRA for the study of interannual variability, as demonstrated for trends in surface $\mathrm{CO}$.

\section{Introduction}

Exploiting the multitude of satellite observations of atmospheric composition (AC) is a key objective of the Copernicus Atmosphere Monitoring Service (CAMS). For its global component CAMS uses the four-dimensional variational (4D-VAR) data assimilation technique to combine satellite observations with chemistry-aerosol modelling to obtain a gridded continuous representation (analysis) of the mass mixing ratios of atmospheric trace gases and aerosols.

The global CAMS system is built on the heritage of the EU-funded GEMS project (Hollingsworth et al., 2008) and a series of Monitoring Atmospheric Composition and Climate (MACC) projects at the European Centre for Medium-Range Weather Forecasts (ECMWF). During these projects the Integrated Forecasting System (IFS) of ECMWF was extended by modules for atmospheric chemistry, aerosols and greenhouse gases in such a way that the 4D-VAR data assimilation system, which had been developed for the analysis of the me- 
teorological fields, could be used for the assimilation of AC retrievals.

Assimilating satellite $\mathrm{AC}$ retrievals into an $\mathrm{AC}$ model has advantages over the sole use of the AC retrievals because of their specific limitations. First, only a small subset of the trace gases or only total aerosol is directly observable with an accuracy sufficient to have an impact during the assimilation. Second, AC satellite retrievals have incomplete horizontal coverage because of the orbital cycle, viewing geometry, the presence of clouds and other factors such as surface albedo. Third, the vertical distribution of the trace species can often not or only coarsely be retrieved from the satellite observations, while the measurement sensitivity towards the surface is generally low.

The AC analyses are used (i) to initialise AC model forecasts and (ii) for the retrospective analysis (reanalysis) of AC for air quality and climate studies. The reanalysis of the meteorological fields has been an important activity at ECMWF (ERA-40, Uppala et al., 2005; ERA interim, Dee et al., 2011) and other meteorological centres such as National Centers for Environmental Protection (NCEP) (CFSR; Saha et al., 2010, JMA (JRA-55, JRA-25; Onogi et al., 2007)) and NASA-DAO (MERRA; Rienecker, et al., 2011). An important application of these reanalysis data sets is the estimation of the interannual variability and the trends of climate variables over the last decades up to the present day. The complete spatial and temporal coverage makes the trend analysis of reanalyses more robust and universal than the trend analysis of individual observing systems. However, constructing a data set, which is suited for this purpose, is a complex task because of the developing and changing observing system, which can introduce spurious trends and sudden shifts in the reanalysis data record. Careful quality control of the assimilated observations and techniques (e.g. Dee et al., 2004) to address inter-instrument biases are applied to mitigate this problem.

Most meteorological reanalyses contain stratospheric ozone, but other trace gases, apart from water vapour, are not included. In the last decade chemical and aerosol data assimilation has matured (Bocquet et al., 2015) and dedicated reanalysis data sets for $\mathrm{AC}$ have emerged. The multi-sensor reanalysis of total ozone (van der A et al., 2015) for 1970-2012 used ground-based Brewer observations to inter-calibrate satellite retrievals. The MERRAero reanalysis (2002-present, http://gmao.gsfc.nasa.gov/ reanalysis/merra/MERRAero/) assimilated aerosol optical depth (AOD) retrievals from the two Moderate Resolution Imaging Spectroradiometer (MODIS) instruments in the GOCART aerosol module of the GEOS-5 model system using the meteorological variables of the MERRA meteorological analysis. Its next version, the MERRA2 reanalysis, is a joint meteorological and aerosol reanalysis covering the period from 1979 to present. Miyazaki et al. (2015) put together a tropospheric chemistry reanalysis using a Kalman filter approach for the years 2005-2012. They use the CHASER chemical transport model (CTM) to assimilate retrievals of tropospheric ozone and $\mathrm{CO}$ profiles, $\mathrm{NO}_{2}$ tropospheric columns, and $\mathrm{HNO}_{3}$ stratospheric columns. Their approach tackles two specific challenges of AC data assimilation. First, they not only correct atmospheric concentrations but also alter the surface emissions that control the tracer distributions to a large extent. Second, the Kalman filter develops covariances of the errors between observed and unobserved species, which are used to correct unobserved species based on the observation increments.

The MACC reanalysis (MACCRA) of reactive gases (Inness et al., 2013) and aerosols for the period 2003-2012 is an AC reanalysis that covers tropospheric and stratospheric reactive gases and aerosols as well as the meteorological fields in one consistent data set. MACCRA has proved to be a realistic data set as shown in several evaluation studies for reactive gases (Elguindi et al., 2010; Inness et al., 2013; Katragkou et al., 2015; Gaudel et al., 2015) and aerosols (Cesnulyte et al., 2014; Cuevas et al., 2015). MACCRA is widely used, for example, as a boundary condition for regional models (Schere et al., 2012; Im et al., 2015; Giordano et al., 2015), to construct trace gas climatologies for the IFS radiation schemes (Bechtold et al., 2009), to estimate aerosol radiative forcing (Bellouin et al., 2013), as input for solar radiation schemes for solar energy applications, and to report the current state of aerosol and $\mathrm{CO}$ as part of the climate system (Benedetti et al., 2014; Flemming and Inness, 2014).

CAMS is committed to producing a comprehensive highresolution AC reanalysis in the next years. The CAMS interim Reanalysis (CAMSiRA) presented here has an interim status between MACCRA and this planned analysis data set. It was produced at a lower horizontal resolution $(110 \mathrm{~km})$ than the resolution of MACCRA $(80 \mathrm{~km})$, and the number of archived AC fields was limited to the aerosol variables and selected chemical species such as ozone, $\mathrm{HNO}_{3}, \mathrm{~N}_{2} \mathrm{O}_{5}, \mathrm{NO}$, $\mathrm{NO}_{2}, \mathrm{PAN}$ and $\mathrm{SO}_{2}$.

The reasons for producing CAMSiRA before the more comprehensive reanalysis are as follows: the MACCRA for reactive gases was produced using a coupled system consisting of the IFS and the MOZART-3 (Kinnison et al., 2007) CTM as described in Flemming et al. (2009). This coupled system was replaced by the much more computationally efficient online coupled model C-IFS (Flemming et al., 2015), which uses the chemical mechanism CB05 of the TM5 CTM (Huijnen et al., 2010). With the discontinuation of the coupled system it was not possible to extend the MACC reanalysis to the present day. For the AC monitoring service of CAMS, it is however important to be able to compare the present conditions with previous years in a consistent way. Another motivation for producing CAMSiRA was that the aerosol module used for the MACCRA had undergone upgrades (Morcrette et al., 2011) in recent years. Finally, MACCRA suffered from small but noticeable shifts because of changes in the assimilated observations, the emission data and the bias correction approach. These spurious shifts un- 
dermine the usefulness of the MACCRA for the reliable estimation of trends. The lessons learnt from the evaluation of CAMSiRA will feed into the set-up of the planned CAMS reanalysis.

Reanalyses of AC are generally less well-constrained by observations than meteorological reanalyses because of the aforementioned limitations of the AC observations and because of the strong impact of the emissions, which are in many cases not constrained by observations. It is therefore good scientific practice to investigate the impact of the $\mathrm{AC}$ assimilation by comparing the $\mathrm{AC}$ reanalysis to a control experiment that did not assimilate AC observations. The control run (CR) for CAMSiRA was carried out using the same emission data as well as the meteorological fields produced by CAMSiRA.

The purpose of this paper is firstly to document the model system, the emissions, and the assimilated observations used to produce CAMSiRA and secondly to highlight its differences to the set-up of the MACCRA. Since the emissions are important drivers for variability of $\mathrm{AC}$, a presentation of the totals and the interannual variability of the emission data used in CAMSiRA and the CR is given in a Supplement to the paper.

In the remainder of the paper, $\mathrm{CO}$, aerosol as well as tropospheric and stratospheric ozone of CAMSiRA, the CR and MACCRA are inter-compared and evaluated with independent observations in a separate section for each species. The comparison of CAMSiRA with MACCRA has the purpose of reporting progress of and issues with CAMSiRA for potential users of the data sets. The comparison of CAMSiRA with the CR shows the impact of the data assimilation and is helpful to better understand deficiencies of the C-IFS model and its input data.

Each section starts with a discussion of the spatial differences of CAMSiRA, the CR and MACCRA for the considered species. Next, the temporal variability is investigated using time series of monthly mean values averaged over selected regions. We present global burdens and discuss changes in the speciation of the aerosol fields introduced by the assimilation. Finally, the three data sets are compared with independent observations, which were not used in the assimilation. A summary and recommendations for future $\mathrm{AC}$ reanalysis will be given in the last section.

\section{Description of CAMSiRA setup}

\subsection{Overview}

CAMSiRA is a data set of 6-hourly reanalyses of AC for the period 2003-2015. A 3-hourly data set consistent with the $\mathrm{AC}$ analysis is available from forecasts linking the analyses. The horizontal resolution is about $110 \mathrm{~km}$ on a reduced Gaussian grid (T159) and the vertical discretization uses 60 levels from the surface to a model top of $0.1 \mathrm{hPa}$. Total columns of carbon monoxide (TC CO) form the Measurements Of Pollution In The Troposphere (MOPITT) instrument, MODIS AOD, and several ozone TC and stratospheric profile retrievals (see Table 2) were assimilated together with meteorological in situ and satellite observations.

The description of MACCRA for reactive gases can be found in Inness et al. (2013). Important commonalities and differences between the two $\mathrm{AC}$ reanalyses are given in $\mathrm{Ta}-$ ble 1 .

The control run is a forward simulation of C-IFS in monthly segments. The meteorological simulation is relaxed using the approach by Jung et al. (2008) to the meteorological reanalysis produced by the CAMSiRA. The emission input fields are the same as those used for CAMSiRA.

\subsection{C-IFS model}

The model C-IFS is documented and evaluated in Flemming et al. (2015). C-IFS applies the chemical mechanism CB05, which describes tropospheric chemistry with 55 species and 126 reactions. Stratospheric ozone chemistry in C-IFS is parameterized by the "Cariolle-scheme" (Cariolle and Dèquè, 1986; Cariolle and Teyssèdre, 2007). Chemical tendencies for stratospheric and tropospheric ozone are merged at an empirical interface of the diagnosed tropopause height in CIFS. C-IFS benefits from the detailed cloud and precipitation physics of the IFS for the calculation of wet deposition and lightning $\mathrm{NO}$ emission. Wet deposition modelling for the chemical species is based on Jacob (2000) and accounts for the subgrid scale distribution of clouds and precipitation. Dry deposition is modelled using precalculated monthly mean dry deposition velocities following Wesely (1989) with a superimposed diurnal cycle. Surface emissions and dry deposition fluxes are applied as surface boundary conditions of the diffusion scheme. Lightning emissions of NO were calculated based on convective precipitation (Meijer et al., 2001).

The aerosol module (Morcrette et al., 2009) is a bulk-bin scheme simulating desert dust, sea salt at $80 \%$ relative humidity $(\mathrm{RH})$, hydrophilic and hydrophobic organic carbon and black carbon as well as sulfate aerosol based on the the LMDZ model of Laboratoire de Météorologie Dynamique aerosol model (Reddy et al., 2005). Sea salt and desert dust are represented in three size bins. The radius ranges of the dust bins are 0.030-0.55, 0.55-0.9 and 0.9-20 $\mu \mathrm{m}$ (DD1, DD2, and DD3), and for the sea salt at $80 \%$ RH bins are $0.03-0.5,0.5-5$ and 5-20 $\mu \mathrm{m}$ (SS1, SS2, and SS3). There is no consideration of the aerosol growth, which would transfer aerosol mass from one size bin to another. Hygroscopic growth of hydrophilic species is taken into account in the computation of the aerosol optical properties only. Following the emission release, the aerosol species are subject to wet and dry deposition and the largest size bins of sea salt and dust are also subject to sedimentation. The chemical source of sulfate is modelled by climatological conversion rates using a $\mathrm{SO}_{2}$ tracer, which is independent of the $\mathrm{SO}_{2}$ simulated 
Table 1. Important commonalities and differences between MACCRA and CAMSiRA.

\begin{tabular}{|c|c|c|}
\hline & MACCRA & CAMSiRA \\
\hline Period & $01 / 2003-12 / 2012$ & $01 / 2003-12 / 2015$ \\
\hline Horizontal resolution & $80 \mathrm{~km}(\mathrm{~T} 255)$ & $110 \mathrm{~km}(\mathrm{~T} 159)$ \\
\hline Vertical resolution & 60 layers from surface to $0.1 \mathrm{hPa}$ & as MACCRA \\
\hline Anthropogenic emissions & $\begin{array}{l}\text { MACCity (trend: ACCMIP + RCP } \\
\text { 8.5), AEROCOM }\end{array}$ & $\begin{array}{l}\text { as MACCRA \& CO emission upgrade } \\
\text { Stein et al. (2014) }\end{array}$ \\
\hline Chemistry module & MOZART-3 & C-IFS CB05/Cariolle ozone \\
\hline Assimilated CO observations & $\begin{array}{l}\text { MOPITT (V4) \& IASI } \\
\text { (from } 2008 \text { onwards) }\end{array}$ & $\begin{array}{l}\text { MOPITT (V5) \& updated error } \\
\text { statistics Inness et al. (2015) }\end{array}$ \\
\hline Assimilated ozone observations & $\begin{array}{l}\text { SBUV-2, OMI, MLS, GOME-2, } \\
\text { SCIAMACHY, GOME, MIPAS } \\
(01 / 2003-06 / 2004)\end{array}$ & as MACCRA \& MIPAS (2003-2012) \\
\hline Ozone MLS bias correction & On & Off \\
\hline Assimilated AOD observations & MODIS (Aqua and Terra) + VarBC & as MACCRA \\
\hline Fire emissions & $\begin{array}{l}\text { GFED (2003-2008) and } \\
\text { GFAS v0 (2009-2012) }\end{array}$ & GFAS v 1.2 (2003-2015) \\
\hline IFS model version & CY36R2 & CY40R2 \\
\hline Assimilation method and model & ECMWF 4D-VAR & as MACCRA \\
\hline $\begin{array}{l}\text { Meteorological observations } \\
\text { assimilated }\end{array}$ & $\begin{array}{l}\text { ECMWF RD setup (satellites, } \\
\text { sondes, surface ) }\end{array}$ & as MACCRA \\
\hline
\end{tabular}

in $\mathrm{CB} 05$. The $\mathrm{SO}_{2}$ tracer is driven by prescribed $\mathrm{SO}_{2}$ and dimethyl sulfide (DMS) emissions. Its loss is simulated by wet and dry deposition as well as the climatological chemical conversion to $\mathrm{SO}_{4}$.

The aerosol and chemistry modules used to simulate source and sink terms are not coupled. Wet and dry deposition are also modelled with different parameterisations but with the same meteorological input as precipitation fields. Aerosol and chemistry have in common that they are advected and vertically distributed by diffusion and convection in the same way. A proportional mass fixer as described in Diamantakis and Flemming (2014) is applied for all tracers in C-IFS.

\subsection{Emission data sets}

This section only references the origin of the emission data. The emitted totals and the linear trends of the anthropogenic, biomass burning, and natural emissions as well as the modelled desert dust and sea salt emissions used in CAMSiRA and the CR are presented in a Supplement.

The anthropogenic surface emissions for the chemical species were taken from the MACCity inventory (Granier et al., 2011), which covers the period 1960-2010. MACCity emissions are based on the ACCMIP (Lamarque et al., 2013) inventory but have improved seasonal variability. The changes from 2000 to 2005 and for 2010 are obtained in the MACCity data using the representative concentration pathway (RCP) scenario version 8.5. For the production of CAMSiRA, the MACCity data set was extended to 2015 by also applying the RCP 8.5 scenario. The anthropogenic CO emissions were increased following Stein et al. (2014). Time se- ries of the anthropogenic $\mathrm{CO}$ emissions for Europe, North America, East Asia (see Table 3) and the globe are shown in Fig. S2 of the Supplement.

The anthropogenic emissions of organic matter, black carbon and aerosol precursor $\mathrm{SO}_{2}$ are retrieved from the AEROCOM database, which is compiled using EDGAR and SPEW data (Dentener et al., 2006). In contrast to the anthropogenic gas emissions, the aerosol anthropogenic emissions did not account for trends but only for the seasonal cycle.

The biogenic emissions for the chemical species were simulated offline by the MEGAN2.1 model (Guenther et al., 2006) for the 2000-2010 period (MEGAN-MACC, Sindelarova et al., 2014). For the remaining years 2011-2015 a climatology data set of the MEGAN-MACC data was put together. Natural emissions from soils and oceans for $\mathrm{NO}_{2}$, DMS and $\mathrm{SO}_{2}$ were taken from the POET (Precursors of ozone and their Effects in the Troposphere) database for 2000 (Granier et al., 2005; Olivier et al., 2003).

Daily biomass burning emissions for reactive gases and aerosols were produced by the Global Fire Assimilation System (GFAS) version 1.2, which is based on satellite retrievals of fire radiative power (Kaiser et al., 2012). This is an important difference with respect to the MACCRA, which used early versions of the Global Fire Emissions Database (GFED 3.1) data from 2003 until the end of 2008 and daily GFAS v1.0 data from 2009 to 2012 . The GFED 3.1 is on average $20 \%$ lower than GFAS v1.2 (Inness et al., 2013). Time series of the biomass burning $\mathrm{CO}$ emissions for tropical Africa, South America, Maritime South East Asia (see Table 3) and the globe are shown in Fig. S3. 
Table 2. Assimilated satellite observations in CAMSiRA.

\begin{tabular}{|c|c|c|c|c|c|}
\hline Instrument & References & Version & Period & Type & Data usage \\
\hline $\begin{array}{l}\text { MOPITT } \\
\text { Terra }\end{array}$ & Deeter et al. (2011) & $\begin{array}{l}\text { V5 TIR } \\
\text { NRT }\end{array}$ & $\begin{array}{l}\text { 2003/01/01- } \\
2012 / 12 / 18 \\
\text { From } \\
2012 / 12 / 19\end{array}$ & $\mathrm{CO} \mathrm{TC}$ & $\begin{array}{l}65^{\circ} \mathrm{N}-65^{\circ} \mathrm{S} \\
\mathrm{QC}=0\end{array}$ \\
\hline $\begin{array}{l}\text { GOME } \\
\text { ERS-2 }\end{array}$ & Munro et al. (1998) & & $\begin{array}{l}2003 / 01 / 01- \\
2003 / 05 / 31\end{array}$ & $\mathrm{O}_{3}$ profile & $\begin{array}{l}80^{\circ} \mathrm{N}-80^{\circ} \mathrm{S} \\
\mathrm{SOE}>15, \\
\mathrm{QC}=0\end{array}$ \\
\hline $\begin{array}{l}\text { GOME-2 } \\
\text { Metop A }\end{array}$ & Hao et al. (2014) & $\begin{array}{l}\text { NRT GDP4.4 } \\
\text { NRT GDP4.7 }\end{array}$ & $\begin{array}{l}\text { 2012/09/01- } \\
2013 / 07 / 14 \\
\text { From } \\
2013 / 07 / 15\end{array}$ & $\mathrm{O}_{3} \mathrm{TC}$ & $\begin{array}{l}\mathrm{SOE}>10 \\
\mathrm{QC}=0\end{array}$ \\
\hline $\begin{array}{l}\text { GOME-2 } \\
\text { Metop B }\end{array}$ & Hao et al. (2014) & NRT GDP4.7 & $\begin{array}{l}\text { From } \\
2014 / 01 / 01\end{array}$ & $\mathrm{O}_{3} \mathrm{TC}$ & $\begin{array}{l}\mathrm{SOE}>10 \\
\mathrm{QC}=0\end{array}$ \\
\hline $\begin{array}{l}\text { MIPAS } \\
\text { Envisat }\end{array}$ & $\begin{array}{l}\text { von Clarmann } \\
\text { et al. }(2003,2009)\end{array}$ & $\begin{array}{l}\text { NRT } \\
\text { CCI }\end{array}$ & $\begin{array}{l}2003 / 01 / 01- \\
2004 / 03 / 26 \\
2005 / 01 / 27- \\
2012 / 03 / 31\end{array}$ & $\mathrm{O}_{3}$ profile & $\mathrm{QC}=0$ \\
\hline $\begin{array}{l}\text { MLS } \\
\text { Aura }\end{array}$ & Froidevaux et al. (2008) & $\begin{array}{l}\text { V2 } \\
\text { NRT V3.4 }\end{array}$ & $\begin{array}{l}\text { 2004/08/08- } \\
2012 / 12 / 31 \\
\text { From } \\
2013 / 01 / 07\end{array}$ & $\mathrm{O}_{3}$ profile & $\mathrm{QC}=0$ \\
\hline $\begin{array}{l}\text { OMI } \\
\text { Aura }\end{array}$ & Liu et al. (2010) & $\begin{array}{l}\text { V003 } \\
\text { NRT }\end{array}$ & $\begin{array}{l}\text { 2004/10/01- } \\
2012 / 12 / 31 \\
\text { From } \\
\text { 2013/01/01 }\end{array}$ & $\mathrm{O}_{3} \mathrm{TC}$ & $\begin{array}{l}\mathrm{SOE}>10 \\
\mathrm{QC}=0\end{array}$ \\
\hline $\begin{array}{l}\text { SBUV/2 } \\
\text { NOAA-16 }\end{array}$ & Bhartia et al. (1996) & V8 & $\begin{array}{l}2004 / 01 / 01- \\
2008 / 10 / 20\end{array}$ & $\mathrm{O}_{3}$ PC 6 layers & $\begin{array}{l}\mathrm{SOE}>6 \\
\mathrm{QC}=0\end{array}$ \\
\hline $\begin{array}{l}\text { SBUV/2 } \\
\text { NOAA-17 }\end{array}$ & Bhartia et al. (1996) & V8 & $\begin{array}{l}2003 / 01 / 01- \\
2012 / 11 / 30\end{array}$ & $\mathrm{O}_{3}$ PC 6 layers & $\begin{array}{l}\mathrm{SOE}>6 \\
\mathrm{QC}=0\end{array}$ \\
\hline $\begin{array}{l}\text { SBUV/2 } \\
\text { NOAA-18 }\end{array}$ & Bhartia et al. (1996) & V8 & $\begin{array}{l}2005 / 06 / 04- \\
2012 / 12 / 17\end{array}$ & $\mathrm{O}_{3}$ PC 6 layers & $\begin{array}{l}\mathrm{SOE}>6 \\
\mathrm{QC}=0\end{array}$ \\
\hline $\begin{array}{l}\text { SBUV/2 } \\
\text { NOAA-19 }\end{array}$ & Bhartia et al. (1996) & V8 & $\begin{array}{l}\text { From } \\
2009 / 02 / 10\end{array}$ & $\mathrm{O}_{3}$ PC 6 layers & $\begin{array}{l}\mathrm{SOE}>6 \\
\mathrm{QC}=0\end{array}$ \\
\hline $\begin{array}{l}\text { SCIAMACHY } \\
\text { Envisat }\end{array}$ & Eskes et al. (2012) & $\mathrm{CCI}$ & $\begin{array}{l}\text { 2003/01/01- } \\
2012 / 04 / 08\end{array}$ & $\mathrm{O}_{3} \mathrm{TC}$ & $\begin{array}{l}\mathrm{SOE}>6 \\
\mathrm{QC}=0\end{array}$ \\
\hline MODIS/Terra & Remer et al. (2005) & $\begin{array}{l}\text { Col.5 } \\
\text { NRT Col.5 }\end{array}$ & $\begin{array}{l}\text { 2003/01/01- } \\
2008 / 07 / 31 \\
\text { From } \\
\text { 2008/08/01 }\end{array}$ & AOD $550 \mathrm{~nm}$ & $70^{\circ} \mathrm{N}-70^{\circ} \mathrm{S}$ \\
\hline MODIS/Aqua & Remer et al. (2005) & $\begin{array}{l}\text { Col.5 } \\
\text { NRT Col.5 }\end{array}$ & $\begin{array}{l}\text { 2003/01/01- } \\
2008 / 07 / 31 \\
\text { From } \\
2008 / 08 / 01\end{array}$ & AOD $550 \mathrm{~nm}$ & $70^{\circ} \mathrm{N}-70^{\circ} \mathrm{S}$ \\
\hline
\end{tabular}

\subsection{C-IFS data assimilation}

C-IFS uses an incremental 4D-VAR algorithm (Courtier et al., 1994), which minimizes a cost function for selected control variables to combine the model and the observations in order to obtain the best possible representations of the atmospheric fields. The mass mixing ratios of $\mathrm{O}_{3}, \mathrm{CO}$ and total aerosol are incorporated into the ECMWF variational analysis as additional control variables and are minimised together with the meteorological control variables. The assim- ilation of satellite retrieval of the chemical species and total AOD is documented in Inness et al. (2015) and Benedetti et al. (2009). The assimilation of aerosol differs from the assimilation of $\mathrm{CO}$ and ozone because only the total aerosol mass can be constrained by the observations, and information about the speciation must be obtained from the model.

The assimilation of AOD retrievals uses an observation operator that translates the aerosol mass mixing ratios and humidity fields of C-IFS to the respective AOD $(550 \mathrm{~nm})$ values using precomputed optical properties. Total aerosol 


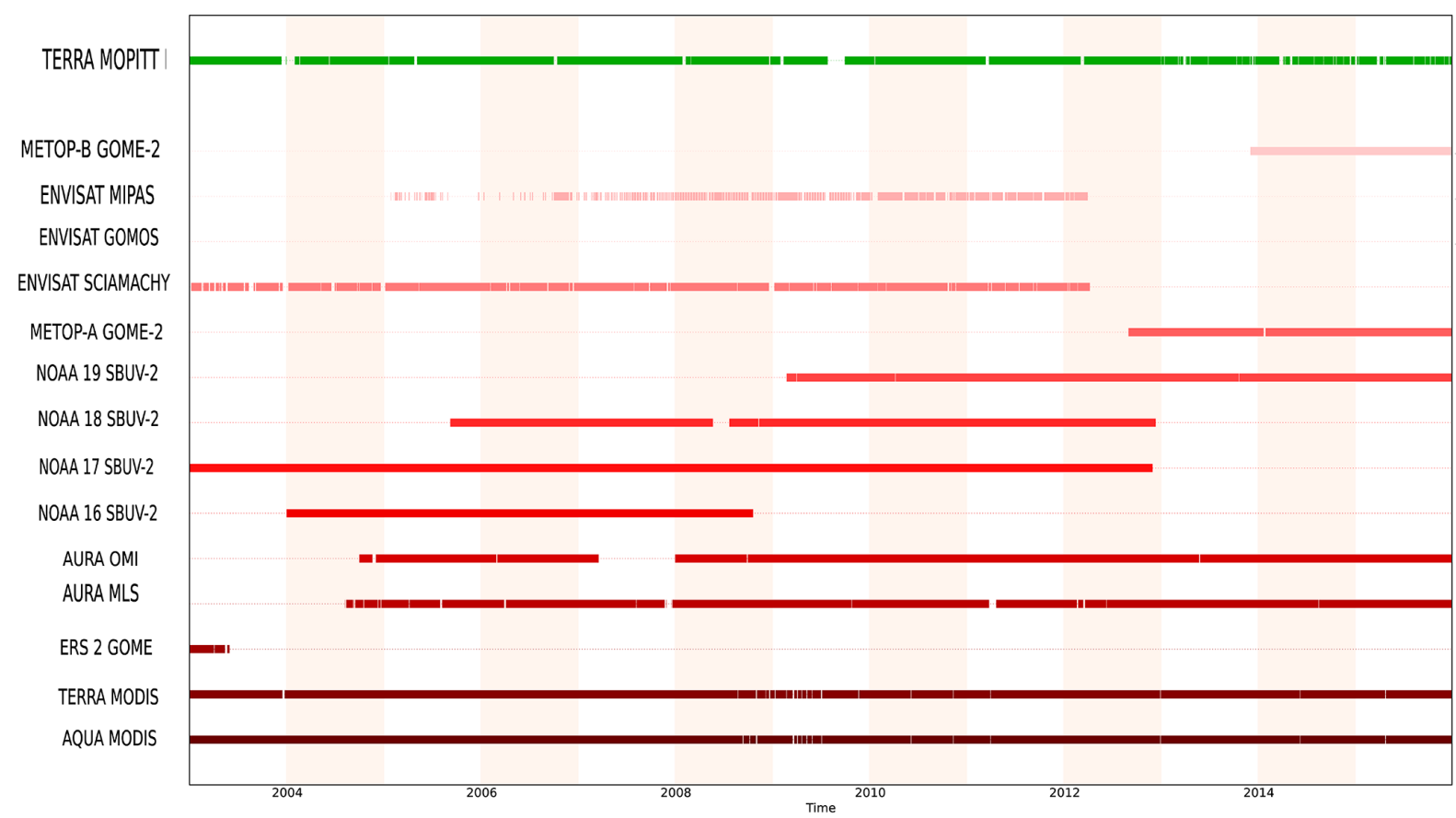

Figure 1. Timeline of assimilated AC satellite retrievals from different instruments assimilated in CAMSiRA (see Table 2).

Table 3. Coordinates of regions.

\begin{tabular}{ll}
\hline Area & Coordinates \\
\hline North America & $165-55^{\circ} \mathrm{W}, 25-75^{\circ} \mathrm{N}$ \\
Europe & $10-45^{\circ} \mathrm{E}, 38-70^{\circ} \mathrm{N}$ \\
East Asia & $90-150^{\circ} \mathrm{E}, 10-55^{\circ} \mathrm{N}$ \\
South America & $82-30^{\circ} \mathrm{W}, 40^{\circ} \mathrm{S}-15^{\circ} \mathrm{N}$ \\
Tropical Africa & $15^{\circ} \mathrm{W}-55^{\circ} \mathrm{E}, 10^{\circ} \mathrm{S}-20^{\circ} \mathrm{N}$ \\
Northern Africa & $15^{\circ} \mathrm{W}-55^{\circ} \mathrm{E}, 20-35^{\circ} \mathrm{N}$ \\
Maritime South East Asia & $90-150^{\circ} \mathrm{E}, 10^{\circ} \mathrm{S}-10^{\circ} \mathrm{N}$ \\
Tropics & $23^{\circ} \mathrm{S}-23^{\circ} \mathrm{N}$ \\
Arctic & $60-90^{\circ} \mathrm{N}$ \\
Antarctica & $90-60^{\circ} \mathrm{S}$ \\
NH mid-latitudes & $30-60^{\circ} \mathrm{N}$ \\
SH mid-latitudes & $60-30^{\circ} \mathrm{S}$ \\
\hline
\end{tabular}

mass mixing ratio is included in the 4D-VAR cost function and the analysis increments are repartitioned into the individual aerosol components according to their fractional contribution to the total aerosol mass. This is an approximation that is assumed to be only valid over the $12 \mathrm{~h}$ of the assimilation window. In reality, the relative fraction of the aerosol components is not conserved during the whole assimilation procedure because of differences in the efficiency of the removal processes. Aerosol components with a longer atmospheric lifetime will retain the change imposed by the increments relatively longer and may thereby change the relative contributions.
In the ECMWF data assimilation system the background error covariance matrix is given in a wavelet formulation (Fisher, 2004, 2006). This allows both spatial and spectral variations in the horizontal and vertical background error covariances. The background errors for $\mathrm{AC}$ are constant in time.

The background errors for ozone are the same as the ones used for MACCRA (Inness et al., 2013). Only the vertical correlations of the ozone background errors were modified and restricted to \pm 5 levels around a model level to avoid correlations between the lower troposphere and upper tropospheric and stratospheric levels that would affect near-surface ozone adversely. The background errors of total aerosol for both MACCRA and CAMSiRA were calculated using the method described in Benedetti and Fisher (2008). The aerosol background errors for CAMSiRA were updated using a more recent C-IFS model version. The background errors for $\mathrm{CO}$ are newly calculated for the CAMSiRA from an ensemble of C-IFS forecast runs (Inness et al., 2015). However, the ensemble did not account for the uncertainty of the emissions, which leads to an underestimation of the background error. This may limit the correcting impact of the observations in the assimilation process.

The background error statistics for the chemical species and for total aerosol are univariate in order to minimise the feedback effects of the chemical fields on the meteorological variables. Correlations between the background errors of different chemical species are also not accounted for (Inness et al., 2015). 
A further potential interaction between the assimilated species could be introduced by the adjoint and tangent linear representations of the chemical mechanism and the aerosol module as part of the 4D-VAR approach. The applied tangent linear and adjoint formulation of C-IFS only accounts for transport processes and not the sources and sinks of atmospheric composition in this study. Because of this limitation and the lack of aerosol or chemistry and meteorology feedbacks in C-IFS, interaction among species and with the meteorology as part of the assimilation procedure are not represented in CAMSiRA.

\subsection{Assimilated observations}

Table 2 shows the AC composition data sets for $\mathrm{CO}$, ozone and AOD that were assimilated in CAMSiRA. The timeline of the assimilation for the different retrievals is shown in Fig. 1. CO is assimilated from MOPITT V5 TIR only, whereas the MACCRA assimilated the V4 TIR product and Infrared Atmospheric Sounding Interferometer (IASI) TC CO retrievals after April 2008. The biases between the retrievals (George et al., 2015) of the two instruments in middle and higher latitudes could not be reconciled with the variational bias correction and led to a discontinuity in the time series of CO in MACCRA, which consequently could not be used for trend analyses (see Fig. 4 below). It was therefore decided to only use the MOPITT V5 CO data set in CAMSiRA because they cover the whole period from 2003 to 2015. The MOPITT V5 product has better long-term stability and a smaller SH bias than V4 (Deeter et al., 2013). V4 suffered from a positive temporal bias drift and a positive bias in the Southern Hemisphere (SH).

Additional ozone data sets in CAMSiRA were the Michelson Interferometer for Passive Atmospheric Sounding (MIPAS) ozone profiles, which were assimilated from 2005 until the end of the ENVISAT mission in April 2012. After the end of 2012 the version of the assimilated Microwave Limb Sounder (MLS) data set changed from V2 to V3.4. Information about the differences between the two versions can be found in https://mls.jpl.nasa.gov/data/v3_data quality_document.pdf

Averaging kernels (AKs) were used for the calculation of the model's first-guess fields in the observation operators for the MOPITT data. For the ozone retrieval, AKs were not used because they were not provided or did not improve the analysis. For example, the high vertical resolution of the MLS ozone retrievals in the stratosphere made the use of AKs unnecessary.

The AC satellite retrievals were thinned to a horizontal resolution of $1^{\circ} \times 1^{\circ}$ by randomly selecting an observation in the grid box to avoid oversampling and correlated observation errors. Variational quality control (Andersson and Järvinen, 1999) and background quality checks were applied. Only "good" data were used in the analysis and data flagged as "bad" by the data providers were discarded.
Variational bias correction (Dee, 2004; McNally et al., 2006; Auligné et al., 2007; Dee and Uppala, 2009) was applied to the MODIS AOD data, as well as to ozone column data from the Ozone Monitoring Instrument (OMI), the SCIAMACHY (SCanning Imaging Absorption spectroMeter for Atmospheric CHartographY) and the Global Ozone Monitoring Experiment 2 (GOME-2). The partial column of the Solar Backscatter Ultraviolet Radiometer-2 (SBUV/2), MLS and MIPAS were used to anchor the bias correction. Experience from the MACC reanalysis had shown that it was important to have an anchor for the bias correction to avoid drifts in the fields (Inness et al., 2013).

\section{Carbon monoxide}

Global CTMs tend to underestimate the observed $\mathrm{CO}$ values in the Northern Hemisphere (NH) (Shindell et al., 2006), but data assimilation (Inness et al., 2013, 2015; Miyazaki et al., 2015; Gaubert et al., 2016) of satellite retrieval is able to successfully reduce the biases of the simulated $\mathrm{CO}$ fields. The correct representation of vertical $\mathrm{CO}$ profiles by the assimilation remains a challenge (Gaudel et al., 2015). An important next step will be the correct representation of the global $\mathrm{CO}$ trends by means of $\mathrm{CO}$ reanalyses such as CAMSiRA.

\subsection{Spatial patterns of total column CO}

Figure 2 shows the seasonal mean of TC $\mathrm{CO}$ over the period 2003-2015 of CAMSiRA and the differences between the CR and MACCRA (2003-2012). Overall, the assimilation of TC CO into CAMSiRA led to an increase in TC CO in the $\mathrm{NH}$ and a decrease in TC CO in the SH and most of the tropics. CAMSiRA was about $2-5 \%$ higher than the CR in the $\mathrm{NH}$ and as much as $20 \%$ lower in the $\mathrm{SH}$. The reduction was especially large in the tropical and subtropical outflow regions of the biomass burning regions in South America, central Africa and Maritime South East Asia. The largest reduction in these regions occurred in December-February (DJF). The largest negative bias of the CR with respect to CAMSiRA occurred over NH in DJF and March-May (MAM). Overall the zonal patterns of the biases throughout all seasons were rather uniform, indicating an underestimation of the hemispheric $\mathrm{CO}$ gradient in the $\mathrm{CR}$. This could point to deficiencies in the simulation of the global chemical loss and production of $\mathrm{CO}$ as well as problems with the large-scale transport. Biases in the amount of the emissions seem to play a smaller role for the problem with the hemispheric gradient.

However, more CO-emission-related differences occurred in September-November (SON) and to a smaller extent in June-August (JJA), when the CR had (i) higher values in the biomass burning regions and the respective outflow regions in Central Africa, Maritime South East Asia, and South America and (ii) lower values in the outflow regions of the emissions in North America and East Asia in the eastern 


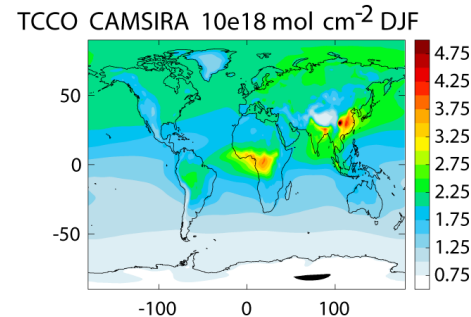

TCCO CAMSIRA $10 \mathrm{e} 18 \mathrm{~mol} \mathrm{~cm}^{-2}$ MAM

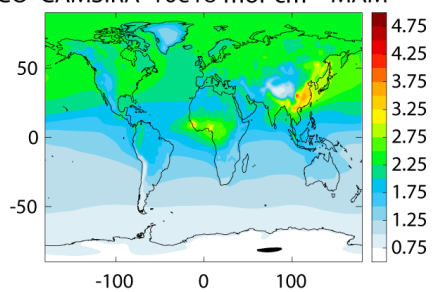

TCCO CAMSIRA $10 \mathrm{e} 18 \mathrm{~mol} \mathrm{~cm}-2 \mathrm{JJA}$

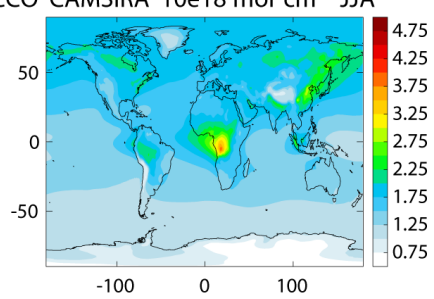

TCCO CAMSIRA $10 \mathrm{e} 18 \mathrm{~mol} \mathrm{~cm}^{-2}$ SON

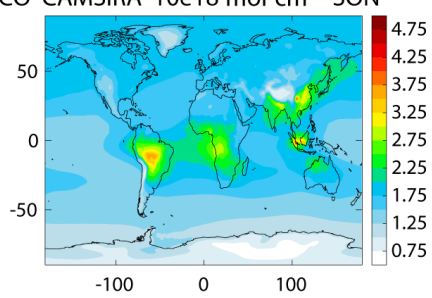

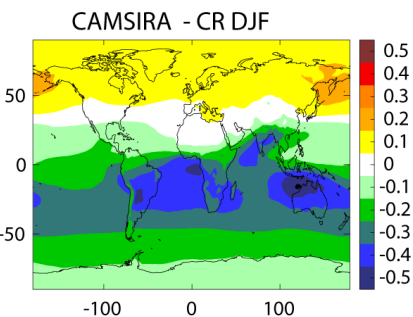
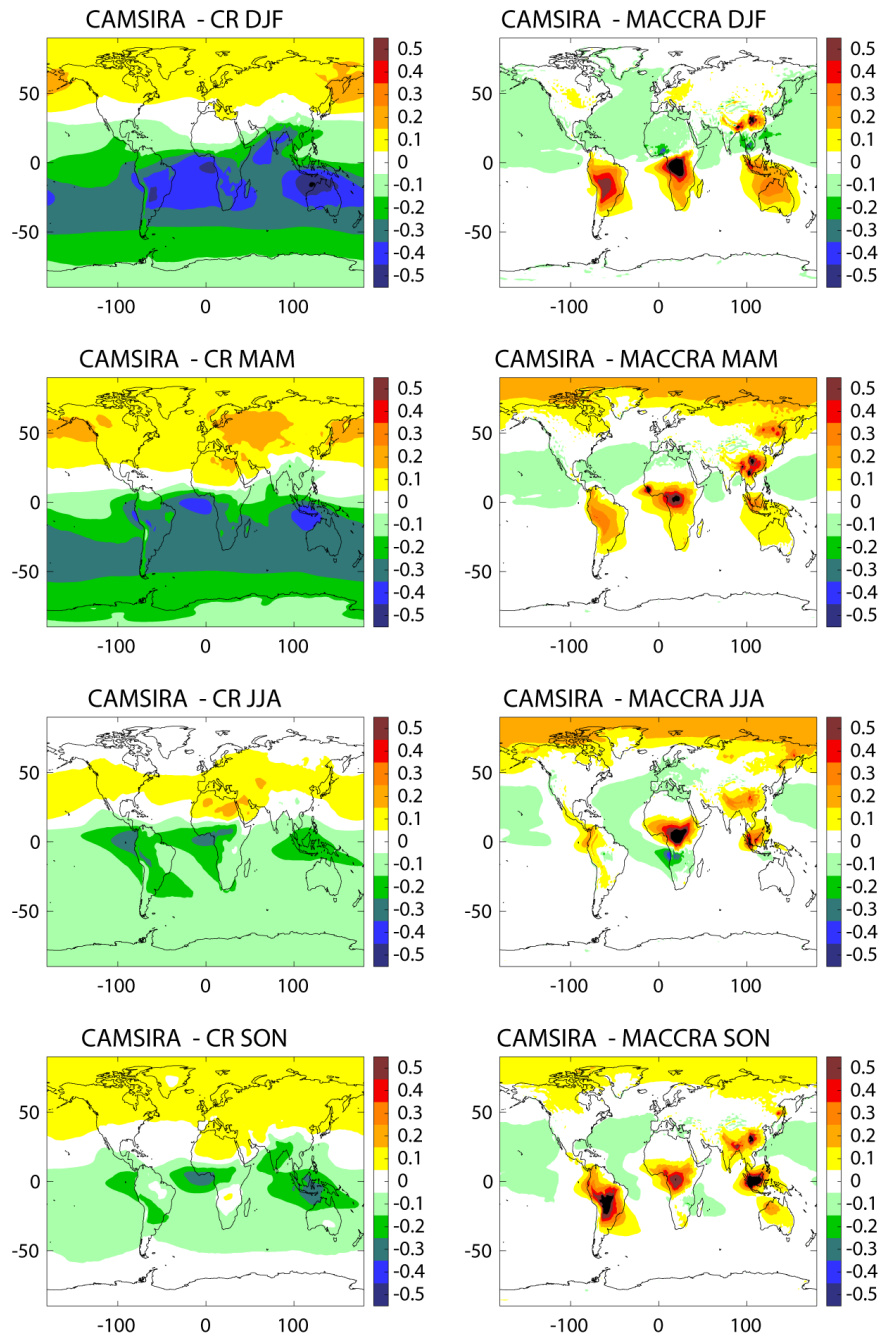

Figure 2. Average TC CO $\left(10^{18} \mathrm{~mol} \mathrm{~cm}^{2}\right)$ of CAMSiRA (2003-2015, left) and difference compared to the CR (2003-2015, middle) and MACCRA (2003-2012, right) for the seasons DJF (row 1), MAM (row 2), JJA (row 3) and SON (row 4).

and western North Pacific. This suggests that GFAS biomass burning emissions were too high, whereas the anthropogenic emissions in North America and East Asia were too low. Conversely, the CR had higher values than CAMSiRA in South Asia, which indicates that the anthropogenic emissions are too high in India.

Compared to MACCRA, CAMSiRA was up to $10 \%$ higher in the northern high latitudes and up to $20 \%$ higher above the tropical biomass burning regions and above parts of East Asia. The differences over the biomass burning regions can be attributed to the different biomass burning emission data sets (see Sect. 2.3). Over the oceans in the $\mathrm{NH}$ and the tropics, apart from biomass burning outflow regions, CAMSiRA CO is slightly lower (3\%) than MACCRA. The differences in the NH high latitudes are mainly caused by the reduction in MACCRA CO in this region introduced by the assimilation of IASI CO retrieval after 2008 (see also Fig. 4 below).

Figure 3 shows the average zonal mean cross section of the CO mass mixing ratio of CAMSiRA and the relative difference to the CR and MACCRA. The overestimation of the $\mathrm{CR}$ in the tropics and $\mathrm{SH}$ extratropics was found throughout the troposphere. It was most pronounced in relative terms at about $500 \mathrm{hPa}$. Stratospheric CO in CAMSiRA was much lower than in MACCRA. This might be an improvement since Gaudel et al. (2015) report an overestimation in the MACCRA over this region. In the upper troposphere CAMSiRA had higher CO than MACCRA, most notably in the tropics and SH where values are up to $40 \%$ higher. CO was lower in the middle and lower troposphere in the SH and higher in the NH. These differences in the vertical distribution might be caused by (i) a more consistent modelling approach of the stratosphere-troposphere exchange with the 
online coupled C-IFS, (ii) the fact that C-IFS CB05 has a very different chemistry treatment compared to MOZART and (iii) updated background error statistics for $\mathrm{CO}$ (see Table 1).

\subsection{Interannual variability of $\mathrm{CO}$ burden}

Figure 4 shows time series of the monthly mean $\mathrm{CO}$ burden from CAMSiRA, MACCRA and the CR for selected areas (see Table 3). The modelled global CO burden (CR) was reduced by the assimilation by about $3 \%$ at the start and by about $7 \%$ at the end of the period. CAMSiRA showed a stepwise decrease in the global CO burden from 2008 and 2009, which corresponds to a significant (95\% confidence level) negative linear trend of $-0.86 \% \mathrm{yr}^{-1}$ over the whole period. The linear trend is as expressed as percentage with respect to the mean of the burden over the whole period. This figure is in good agreement with the results of Worden et al. (2013), who estimated trends of $-1 \%$ per year for both the globe and $\mathrm{NH}$ over the last decade by studying different satellite-based instruments. The CR also showed the largest decrease in the period from 2007 to 2009, but the CO burden increased slightly after that period. The resulting linear trend of the $\mathrm{CR}$ was still negative $\left(-0.36 \% \mathrm{yr}^{-1}\right)$ but less strong than the trend of CAMSiRA.

The higher global CO burdens of the CR with respect to CAMSiRA originated mainly from the tropics and the SH mid-latitudes, which are strongly influenced by biomass burning emissions in tropical Africa and South America. CO was reduced by the assimilation in CAMSiRA, especially after the start of the biomass burning season. The reduction in the biomass burning emissions of $-7.4 \% \mathrm{yr}^{-1}$ (see Supplement Table S1) over South America led to a significant negative trend of the $\mathrm{CO}$ burden of $-1.23 \% \mathrm{yr}^{-1}$ in CAMSiRA and $-0.83 \% \mathrm{yr}^{-1}$ in the CR over that region. The overestimation of the CR with respect to CAMSiRA increased slightly during this period.

2015 was an exceptional year because the global CO burden reached the highest values in the whole period for both CAMSiRA and the CR despite the overall decadal negative trend. The increase was caused by exceptionally high biomass burning emissions in Indonesia because of El Niñorelated dry conditions. The El Niño-controlled interannual variability of CO over Maritime South East Asia was reproduced in a very similar way in CAMSiRA and the CR, but the assimilation reduced the burden by about $1 \mathrm{Tg}(10 \%)$.

In the regions of high anthropogenic emissions the temporal variability on a monthly scale was very similar between the CR and CAMSiRA. Both in North America and Europe, the CR underestimated the CO maximum of CAMSiRA in early spring by less than $5 \%$ up to the year 2010 , but the biases almost disappeared in later years. This means that the negative total CO trend in these regions was larger in CAMSiRA, which contains the MOPITT observations, than in the $\mathrm{CR}$. It could indicate that the anthropogenic emissions were biased low at the beginning of the period but less so towards the end. Over East Asia the difference between the CR and CAMSiRA was generally very small, indicating a high degree of realism of the emissions in the area. A further explanation for this agreement is the fact that this area covers both the underestimation of CAMSiRA by the CR in NH midlatitudes and the overestimation in the tropics. Both CAMSiRA and the CR had a negative but not significant trend over East Asia.

Stroden et al. (2016) also find good agreement between MOPITT-based and modelled negative trends for the 20002010 period of TC CO over Europe and North America but disagreement in the sign of the trend over eastern China, where their model, using MACCity emissions, simulates a positive trend but MOPITT has a negative trend. Over eastern China the CR (2003-2015) also had a small positive linear trend, whereas CAMSiRA had a negative trend; neither trend was statistically significant. The positive trend over eastern China in the CR was mainly driven by directly emitted CO at the surface. Because of the hemispheric influence, i.e. the hemispheric reduction in $\mathrm{CO}$, the $\mathrm{CO}$ trend in the $\mathrm{CR}$ over eastern China became negative in the middle troposphere.

In the Arctic, which is influenced by the long-range transport from North America, Europe and Asia (Emmons et al., 2015), no MOPITT observations were assimilated (see Table 2) because of the higher biases of the MOPITT data in this region. The variability of the CR and CAMSiRA CO burden also matched well in this region, but the bias was much reduced after 2012.

The time series of the global CO burden of CAMSiRA and MACCRA agree better than CAMSiRA and the CR. The global burden of MACCRA is slightly lower than in CAMSiRA (1\%) until 2010 but starts to exceed CAMSiRA in 2011 and 2012. Hence, larger differences occur at the beginning and end of the MACCRA period.

The CO burden of MACCRA above the biomass burning regions of South America and tropical Africa was lower than CAMSiRA for the period 2003-2010. This is most likely because of the use of the GFED biomass burning emissions until 2008, which are on average $20 \%$ lower than GFAS, which was used for CAMSiRA. In the years 2011-2012 MACCRA had higher values, which even led to a reversal in the sign of the trend over the two regions in MACCRA in comparison to CAMSiRA. MACCRA and CAMSiRA agreed well above the anthropogenic source regions. Only from 2008 onwards was MACCRA slightly lower, which led to enhanced negative trends.

Over the Arctic, CAMSiRA is higher from 2008 onwards, whereas MACCRA was higher at the start. This is consistent with the respective trends over Europe and North America. All data sets showed a step-like reduction in the CO burden in mid-2008 but it was most pronounced in MACCRA. 

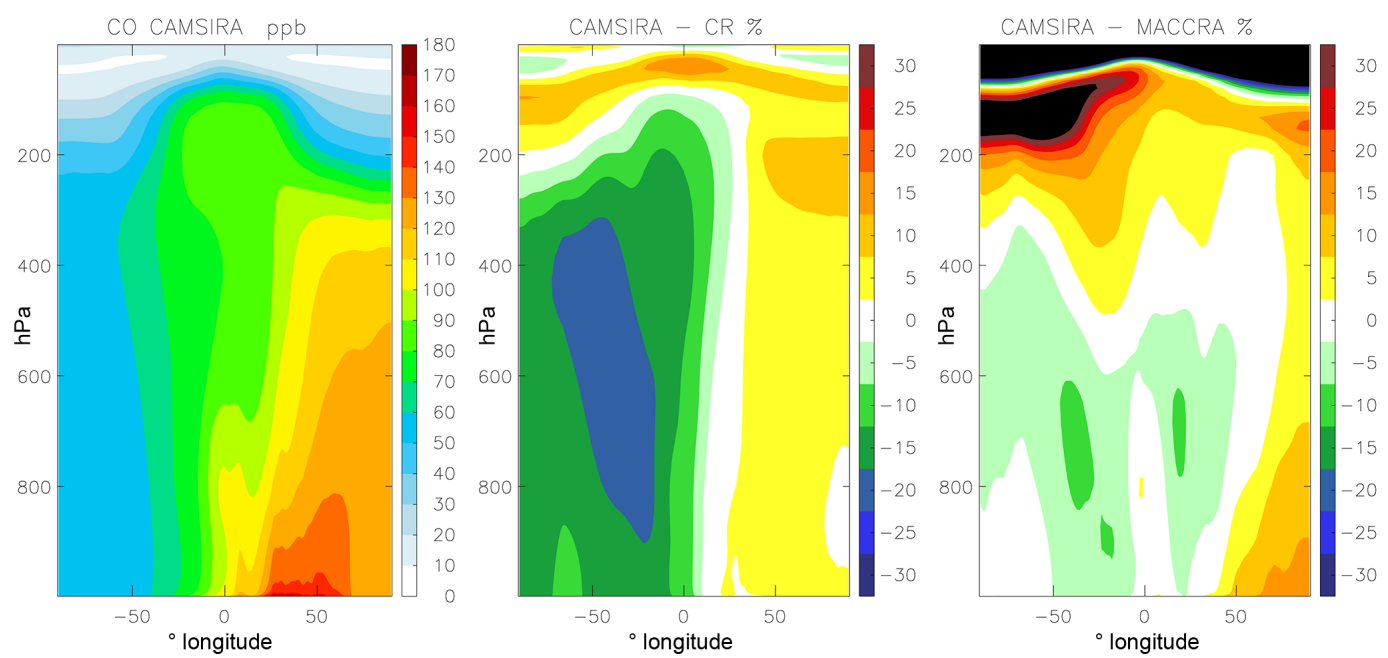

Figure 3. Zonally averaged CO cross section of CAMSiRA (ppb) (2003-2015, left) and relative difference (\%) compared to the CR (20032015, middle) and MACCRA (2003-2012, right).

\subsection{Evaluation with MOZAIC-IAGOS aircraft CO observations}

MOZAIC (Measurements of OZone, water vapour, carbon monoxide and nitrogen oxides by in-service AIrbus aircraft) and IAGOS (In-service Aircraft for a Global Observing System) are subsequent programmes of AC observations mounted on commercial aircraft. The MOZAIC CO data have an accuracy of $\pm 5 \mathrm{ppbv}$, a precision of $\pm 5 \%$ and a detection limit of 10 ppbv (Nédélec et al., 2003). De Laat et al. (2014) compare MOZAIC-IAGOS profiles with the MOPITT v5 NIR retrievals, which were assimilated in CAMSiRA. They find good agreement and no drift of the biases of the two data sets in their study period 2002-2010.

We use the $\mathrm{CO}$ profiles obtained during take-off and landing to evaluate the $\mathrm{CO}$ fields averaged over airports in different regions from 2003 to 2012. The number of MOZAICIAGOS CO profiles fluctuated considerably over the years. They decreased from 2003 to 2014 by about $50 \%$ and certain airports had many more observations than others. Since the aircraft used in MOZAIC were based in Frankfurt, the majority of the $\mathrm{CO}$ profiles were observed at this airport. Therefore the observations from Frankfurt dominate the European mean values. Observations from Tokyo and other Japanese cities were the largest contributions to the mean over East Asia. Atlanta, Toronto and Vancouver had the largest number of observations in the North American domain. Windhoek had by far the largest number of observations in tropical Africa and Caracas had the most in South America. The mean over Maritime South East Asia is mainly calculated from observations over Jakarta and Kuala Lumpur in 2005, 2006 and 2012, with an unbalanced coverage of the difference months.
Profiles of the mean relative bias of CAMSiRA, MACCRA and the CR against MOZAIC-IAGOS CO observations for different regions (see Table 3) averaged over the period 2003-2012 are shown in Fig. 5. We discuss here only the annual biases since the seasonal relative biases did not differ to a large extent from the annual relative biases.

All three data sets underestimated the observed $\mathrm{CO}$ values throughout the troposphere in Europe, North America and East Asia. At the surface and the lower planetary boundary layer up to $900 \mathrm{hPa}$, i.e. where the highest $\mathrm{CO}$ concentrations are observed, CAMSiRA and the CR had relative biases of about $-10 \%$ in Europe and North America and up to $-20 \%$ in East Asia, whereas MACCRA had larger relative biases of -20 to $-30 \%$ at this level. The largest biases occurred in DJF. Conversely, MACCRA had smaller biases than CAMSiRA and the CR in the middle and upper troposphere. The smaller biases of MACCRA may be caused by the more realistic simulation of the chemical $\mathrm{CO}$ production by the MOZART chemical mechanism as well as by the change in the $\mathrm{CO}$ background error statistic. The assimilation of MOPITT in CAMSiRA reduced the biases relative to the CR in the troposphere over Europe and North America but had only little effect at the surface. Over East Asia the assimilation did not lead to changes in the CR and CAMSiRA.

Whereas the CR had the largest underestimation in the $\mathrm{NH}$, it was generally higher than CAMSiRA and MACCRA in the tropics. This led to better agreement with the MOZAIC observations in South America and tropical Africa but also to an overestimation of 20-30\% in Maritime South East Asia. The limited number of observations in that region makes this result less robust. MACCRA and CAMSiRA showed little difference over South America and tropical Africa. The $10 \%$ negative bias of MACCRA and CAMSiRA in tropical Africa is consistent with the $10 \%$ underestimation of MO- 

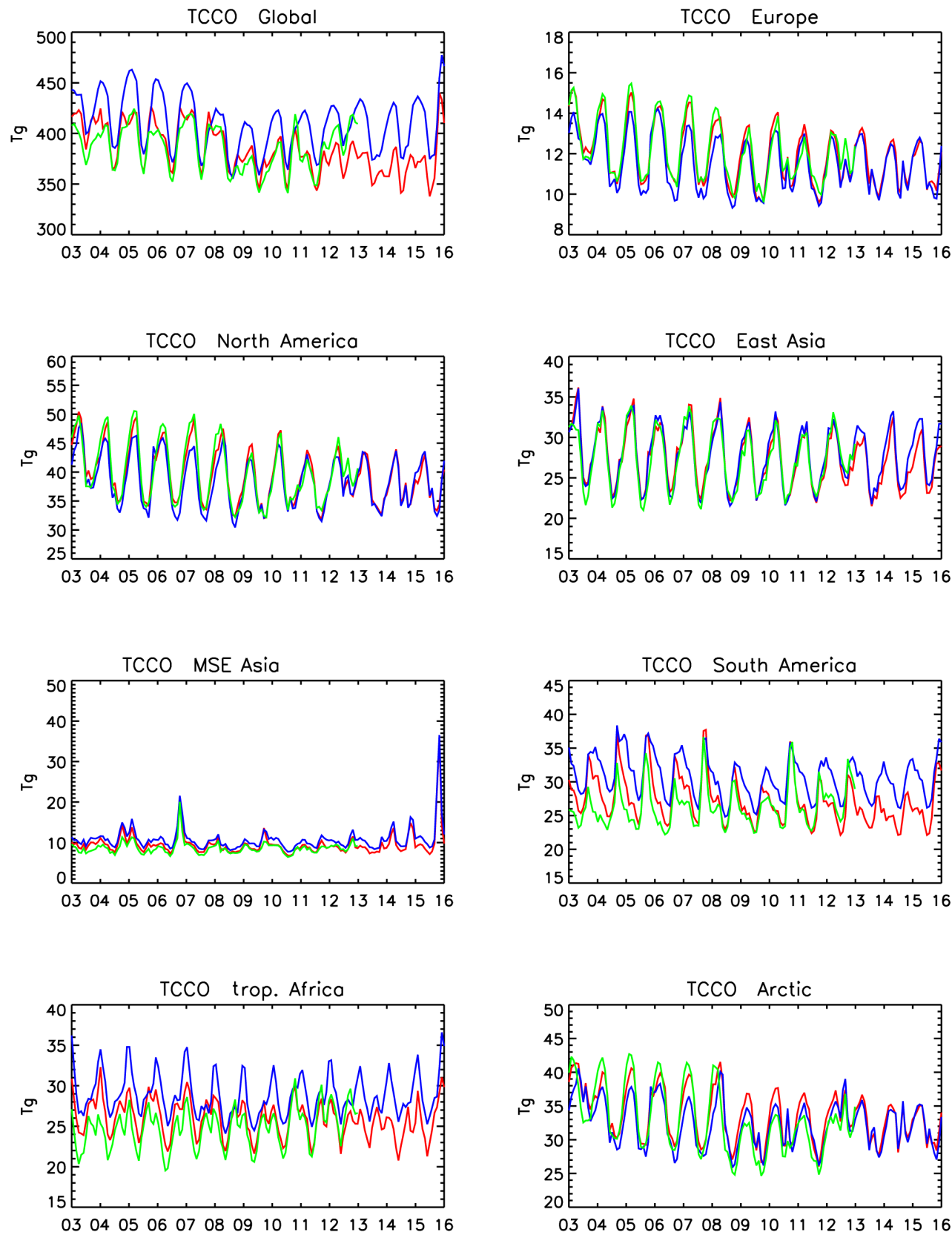

Figure 4. Time series of monthly mean CO burden (Tg) over different regions (see Table 3) for the period 2003-2015 from CAMSiRA (red), the CR (blue) and MACCRA (green, 2003-2012).

PITT v5 against MOZAIC-IAGOS over Windhoek reported by de Laat et al. (2014, their Fig. 3). Over Maritime South East Asia below $700 \mathrm{hPa}, \mathrm{CAMSiRA}$ and MACCRA overestimated CO, whereas MACCRA underestimated the observations. This could be the consequence of the different fire emissions and the different chemistry schemes, but the limited number of available profiles makes this result less representative.

\subsection{Evaluation with NOAA GMD surface observations}

NOAA Global Monitoring Division (GMD) network of flask CO surface observations (Novelli and Masarie, 2010) has good global coverage, which also includes the high latitudes of the $\mathrm{SH}$ and $\mathrm{NH}$, to observe the background concentrations. The tropical stations represent the maritime background because they are mainly located on islands in the tropical oceans. The station density is higher in North Amer- 

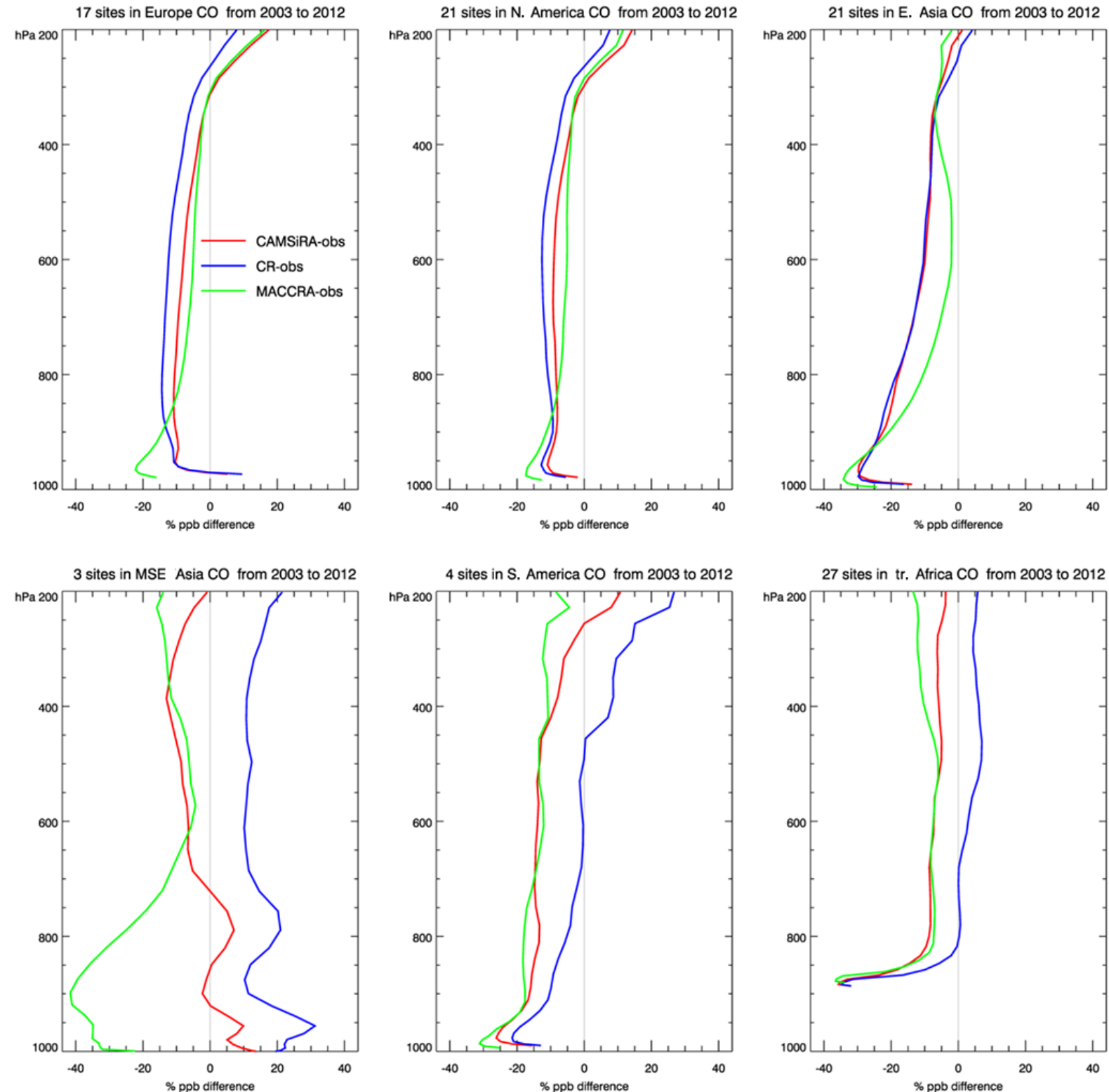

Figure 5. Average relative bias (\%) in CO of CAMSiRA, MACCRA and the CR compared with MOZAIC-IGAOS flight profiles averaged over different regions (see Table 3 ) for the period 2003-2012.

ica and Europe. The uncertainty of the NOAA-GMD CO observations is estimated to be $1-3 \mathrm{ppm}$ (Novelli et al., 2003).

We calculated the mean and, for reasons of simplicity, only the linear trend at each station for the period 2003-2014 or 2003-2012 (MACCRA). The overall bias averaged over all stations of CAMSiRA and the CR was $3.0 \mathrm{ppb}$ for the whole period but CAMSiRA had a slightly lower RMSE (13 ppb) than the CR (15 ppb). For the 2003-2012 period MACCRA had a bias of $6 \mathrm{ppb}$, whereas CAMSiRA and the CR had a bias of 3.1 and $3.9 \mathrm{ppb}$ respectively.

Figure 6 shows the zonal means of the observed averages and the corresponding model values at each station location as well as the median of the estimated linear trend from the observations and the model results. The graphs were constructed by calculating the mean concentrations and median trends of all stations in $15^{\circ}$ wide latitude bins. The errors bars indicate the range of the observed values in the latitude bin.

In the SH high and mid-latitudes, the typical observed annual mean surface concentration was $50 \mathrm{ppbv}$. The background levels started to rise in the southern extratropics and reached a maximum of $145 \mathrm{ppbv}$ in the $\mathrm{NH}$ mid-latitudes. The values then decreased to about $130 \mathrm{ppb}$ in the Arctic. The general structure of the zonal variation was well represented by all data sets. The CR overestimated the SH middle and 

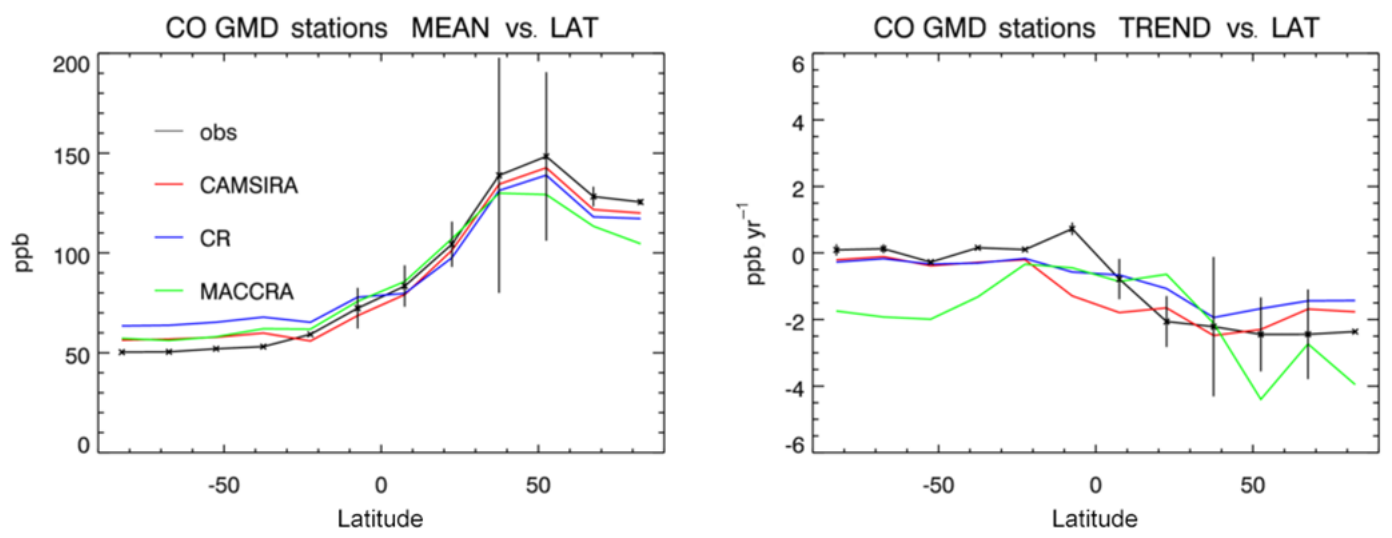

Figure 6. Zonal average of mean surface CO in ppb observed at NOAA-GMD stations (2003-2014), values from CAMSiRA, the CR, and MACCRA (2003-2012) (left) and zonal median of linear trend in $\mathrm{ppb} \mathrm{yr}^{-1}$ (right). The error bars indicate the range of the observed values.

high values by $15 \mathrm{ppb}$, whereas CAMSiRA and MACCRA had a bias of $7 \mathrm{ppb}$. In the tropics CAMSiRA had slightly lower ( $3 \mathrm{ppb}$ ) values than the observations, whereas MACCRA and the CR overestimated by about $5 \mathrm{ppb}$. CAMSiRA had the highest values of all three data sets in the NH midlatitudes but still underestimated the mean of the observations by $7 \mathrm{ppb}$. However, the observed means at the station locations in this latitude band varied in a range of about $100 \mathrm{ppb}$. The CR had a slightly larger underestimation than CAMSiRA. MACCRA underestimated the observations by more than $20 \mathrm{ppb}$ in the middle and high latitudes. The reduction in the NH high latitudes in the CR and CAMSiRA was similar to the observations.

The observations in the SH showed essentially no linear trend in the 2003-2014 period. Starting in the tropics, a negative linear trend gradually occurred, which reached values of about $-2.2 \mathrm{ppb} \mathrm{yr}^{-1}$ in the $\mathrm{NH}$ middle and high latitudes. CAMSiRA and the CR had a small but still significant negative trend in the $\mathrm{SH}$ of -0.3 and $-0.5 \mathrm{ppb} \mathrm{yr}^{-1}$ respectively. The negative trends of CAMSiRA and the CR started to become more pronounced from $20^{\circ} \mathrm{S}$ onwards. The trend in CAMSiRA was generally stronger than the trend in the CR. This meant a better fit with the observed trends in the tropics for the $\mathrm{CR}$ and a better fit in the NH middle and high latitudes for CAMSiRA. In this region the median of the trends was -2.1 for CAMSiRA and $-2.0 \mathrm{ppb} \mathrm{yr}^{-1}$ for the CR. While the trends of CAMSiRA and the CR agreed reasonably well with the observations, MACCRA suffered from unrealistically strong negative trends in the middle and high latitudes of both hemispheres. This negative trend in MACCRA was caused by the reduction in the values related to assimilation of IASI data from 2008 onwards (Inness et al., 2013).

\section{Aerosols}

In contrast to the assimilation of individual chemical gases, the assimilation of AOD observations is "underdetermined" because different combinations of the aerosol components can lead to the same extinction, i.e. AOD value. A further complicating factor is that each aerosol component has different optical properties, which depend on RH for the hydrophilic components such as sea salt, sulfate and organic matter. The correction of the speciation of the assimilated aerosol mass mixing ratio fields is therefore a big challenge despite good success in reproducing independent AOD observations with the aerosol analysis (Eskes et al., 2015).

\subsection{Global aerosol burden, speciation and AOD}

In this section the global averages of burdens and AOD are presented. Spatial patterns of AOD will be discussed in Sect. 4.2. Global area-weighted averages of AOD at $550 \mathrm{~nm}$ and the total global burden in teragrams for the different aerosol components are shown in Fig. 7. The figure also shows the median of the global AOD average and burdens simulated by the models of the AeroCom intercomparison study (Kinne et al., 2006; Textor et al., 2006). The CR had the highest total global average aerosol burden of $46 \mathrm{Tg}$ compared to MACCRA and CAMSiRA, which both had $33 \mathrm{Tg}$. This number was very similar to the AeroCom median of $29 \mathrm{Tg}$.

The global sea salt burden was about twice as high in the CR (15.1 Tg) than in CAMSiRA (8.3 Tg), and it was $16.1 \mathrm{Tg}$ for MACCRA. In comparison, the median of the sea salt burden from the AeroCom models is $6.3 \mathrm{Tg}$. Another study of different emission schemes by Spada et al. (2013) found sea salt burdens in the range from 5.0 to 7.2 Tg. In light of these studies as well as the applied correction by the assimilation in CAMSiRA, the simulated sea salt burden of the CR appears to be too high. The simulated sea salt emissions of C-IFS were within the reported range in the literature (see Supplement). This suggests that the loss processes of sea salt were underestimated in C-IFS in comparison to other models. Conversely, the high sea salt burden of MACCRA was 

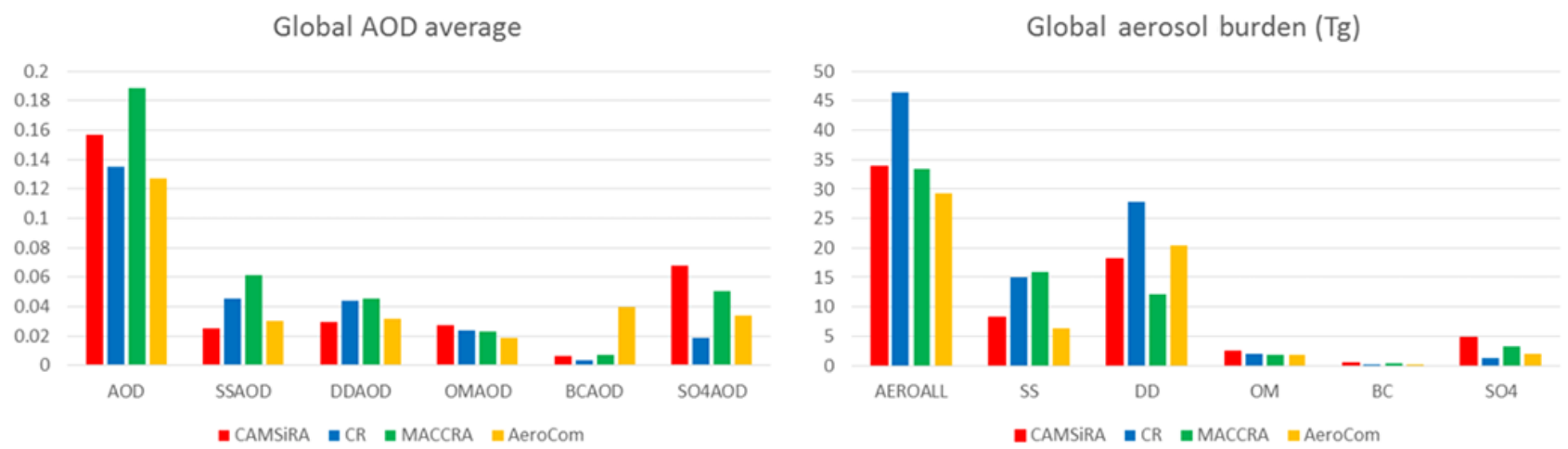

Figure 7. Global average of total AOD $(550 \mathrm{~nm})$ and species AOD (left), global total and species, and burden in teragrams (right) of sea salt (SS), desert dust (DD), organic matter (OM), black carbon (BC), and sulfate aerosol ( $\left.\mathrm{SO}_{4}\right)$ for CAMSiRA (red), the CR (blue), and MACCRA (green) and the median of the AeroCom model intercomparison (yellow, Kinne et al., 2006; Textor et al., 2006).

likely caused by an exaggeration of the sea salt emission by an earlier version of the emissions module.

The desert dust burden in the CR was $27 \mathrm{Tg}$, which was higher than the AeroCom median of $20 \mathrm{Tg}$. It was largely reduced to $18 \mathrm{Tg}$ by the assimilation in CAMSiRA. MACCRA had an even lower desert dust burden of $12 \mathrm{Tg}$ because of the underestimation of the desert dust emissions scheme used in MACCRA. As in the case of the sea salt, the underestimation of the desert dust loss by deposition and sedimentation may play an important role in the overestimation of dust burden in the CR.

The strongest relative change in the global burden by the assimilation occurred for sulfate, which was $1.2 \mathrm{Tg}$ in the CR but was $4.7 \mathrm{Tg}$ in CAMSiRA and $3.3 \mathrm{Tg}$ in MACCRA. The respective AeroCom median value is $2 \mathrm{Tg}$. Because of the larger extinction per unit mass of sulfate, this increase in sulfate had a large impact on total AOD, which will be discussed further below.

The organic matter and black carbon burden of the CR $(0.2$ and $2.0 \mathrm{Tg}$ ) was increased by the assimilation to 0.36 and $2.4 \mathrm{Tg}$ respectively. The values agreed reasonably well with the AeroCom median of 0.21 and $1.76 \mathrm{Tg}$.

In contrast to the global burden, the $\mathrm{CR}$ had the lowest global AOD average of 0.13. CAMSiRA and MACCRA had values of 0.16 and 0.18 . The values for the $C R$ were close to the median of the AeroCom models (0.12), but the two reanalyses had a higher value than the highest global average AOD value of the AeroCom models of 0.15 .

The largest fraction of the CAMSiRA AOD came from sulfate, which was strongly increased by the assimilation. The contribution of sulfate AOD to total AOD was $13 \%$ in the CR and $43 \%$ in CAMSiRA. Sulphate was also the largest AOD contribution in MACCRA. The global average of sulfate AOD of the CR (0.018) was about half of the AeroCom median (0.034), which could suggest an underestimation of the global sulfate burden and AOD in the CR. Conversely, global sulfate AOD of CAMSiRA was 0.06, which was higher than the highest value of the AeroCom model ensemble (0.051).

As already discussed for the respective burdens, global desert dust AOD and sea salt AOD were strongly reduced in CAMSiRA compared to the CR. In the CR, sea salt and desert dust AOD contributed about $30 \%$ each to the total AOD, whereas in CAMSiRA the contribution was reduced to 15 and $19 \%$ respectively. The reduction of sea salt by the assimilation was reasonable since the sea salt burden was above the reported range by Textor (2006) and Spada et al. (2012). However, the reduction in sea salt was compensated for by the increase in sulfate, which became the most important contribution to total AOD over many parts of the ocean.

The global sea salt burden of MACCRA was higher than in CAMSiRA but similar to the CR. However, a different distribution of the mass within the size classes meant that the resulting sea salt AOD of MACCRA was $20 \%$ higher than the CR. MACCRA had the lowest desert dust burden but differences in the size distribution towards smaller particles meant that the resulting AOD was slightly higher than the CR and $20 \%$ higher than CAMSiRA. Black carbon and organic matter AOD and burden were similar among CAMSiRA, the $\mathrm{CR}$ and MACCRA.

\subsection{Spatial patterns of AOD}

Figure 8 shows the annual mean of total AOD and AOD for desert dust, sea salt, sulfate, black carbon and organic matter for the period 2003-2015 from CAMSiRA and the differences compared to the CR and MACCRA (2003-2012). The global maxima of the total AOD (>0.5) in CAMSiRA were found over areas of desert dust emissions such as the Sahara, the Arabian Peninsula and the deserts of central Asia. High emissions of black carbon and organic matter from biomass burning sources in tropical Africa and anthropogenic sources in eastern China and northern India also contributed to AOD maxima on the global scale. 

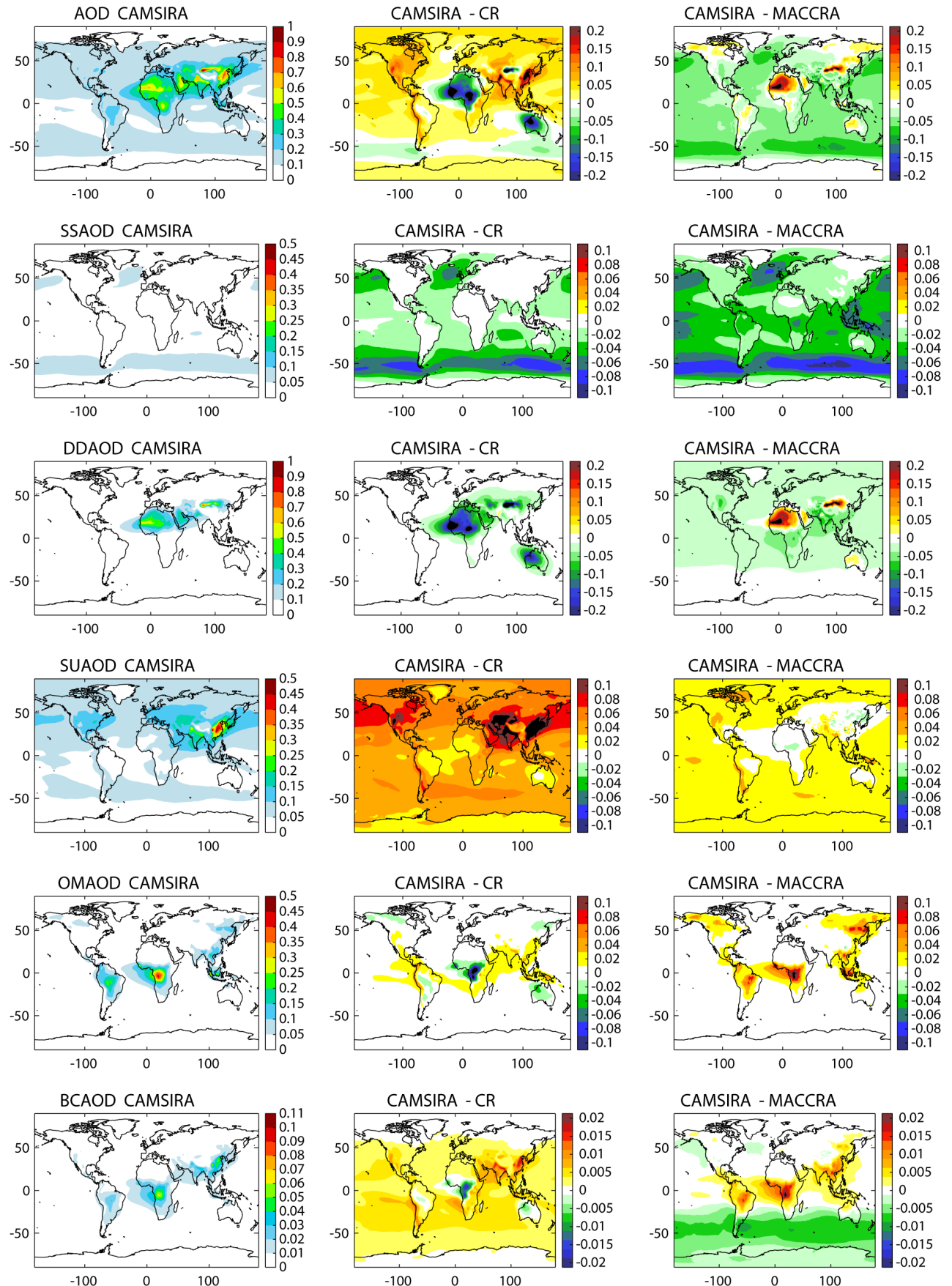

Figure 8. Total average AOD (row 1, scale max 1.0), AOD of desert dust (row 2, 1.0), sea salt (row 3, 0.5), sulfate (row 4, 0.5), organic matter (row 5, 0.5), and black carbon (row 6, 0.11) of CAMSiRA (average 2003-2015, left) and differences compared with the CR (average 2003-2015, middle) and MACCRA (average 2003-2012, right).

The increase in the global average AOD in CAMSiRA with respect to the CR by the assimilation (see Sect. 4.1) occurred in most parts of the globe, in particular over the areas of industrial activity in North America, Europe and East Asia (20-30\%) as well as in the polar regions (>50\%), where AOD is generally low. The differences between the
$\mathrm{CR}$ and CAMSiRA, although varying in magnitude, exhibit similar spatial patterns in all seasons, with the largest differences occurring throughout the NH in MAM. As discussed in Sect. 4.1, the increase is mostly caused by a widespread increase in sulfate AOD. Sulphate AOD increased more strongly in relative terms over the oceans and higher lat- 

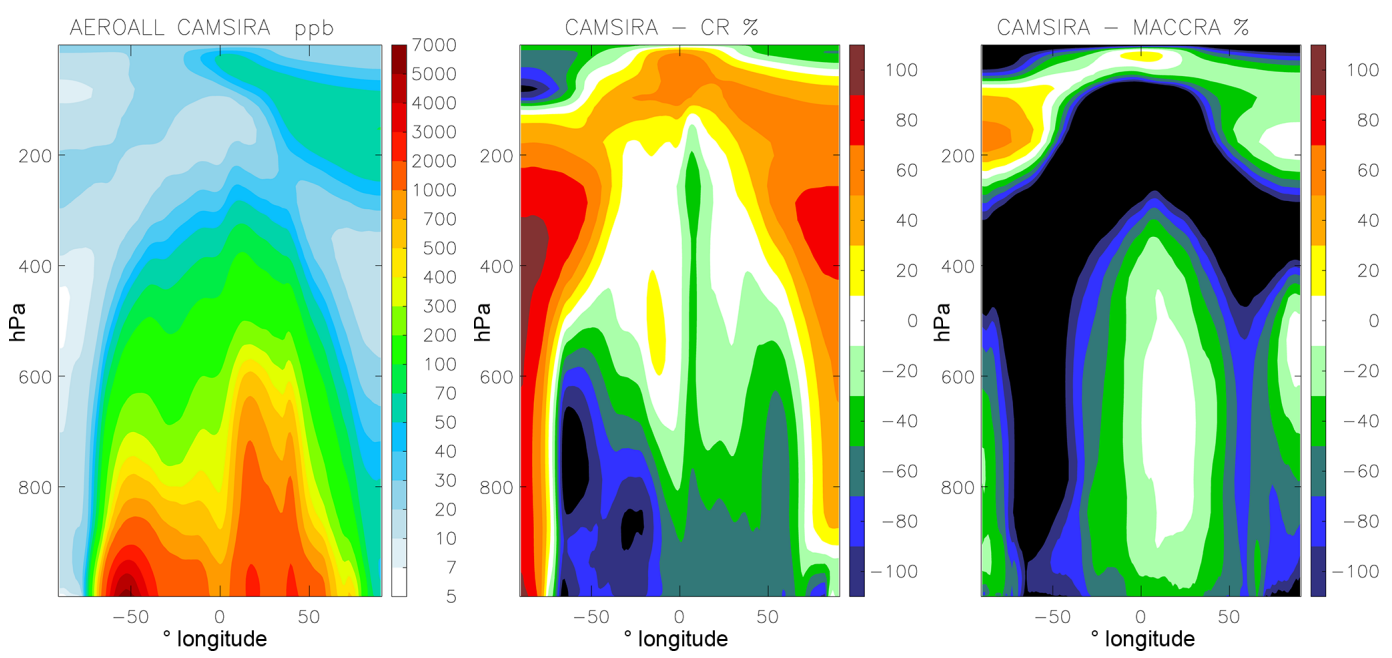

Figure 9. Zonally averaged total aerosol mass mixing ratio $\left(10^{-9} \mathrm{~kg} \mathrm{~kg}^{-1}\right)$ of CAMSiRA (2003-2015, left) and relative difference (\%) compared with the CR (2003-2015, middle) and MACCRA (2003-2012, right).

itudes. In areas of higher modelled sulfate AOD, such as North America, Europe, northern Asia and the Arctic, the contribution to total AOD changed from 40 to $90 \%$, which made sulfate by far the most abundant aerosol species in these areas as well as over the Antarctic, which seems unrealistic given that the global $\mathrm{SO}_{2}$ emission was only less than $2 \%$ of the total aerosol emissions (see Supplement).

The identified reduction of global desert dust in CAMSiRA with respect to the CR was mainly confined to the main desert dust region, where AOD was reduced by by 0.2 . Since total AOD was dominated by desert dust, total AOD was strongly reduced in these regions, whereas total AOD of CAMSiRA was always higher than the CR in other parts of the globe. The largest relative reduction of desert dust AOD occurred in the remote outflow regions from Australia, tropical Africa and Eurasia. The reduction of desert dust occurred throughout all seasons, with the largest reduction in JJA.

The strongest reduction in sea salt occurred in CAMSiRA compared to the CR and occurred over the oceans proportional to the sea salt AOD. Because of the increase in sulfate, the sea salt reduction led only to a small reduction of total AOD over the area of the highest sea salt emissions in the North Atlantic in DJF and over the Southern Ocean in JJA and MAM. The contribution of sea salt AOD to total AOD over most of the ocean was changed from more than $80 \%$ in the CR to $50 \%$ in CAMSiRA in middle and high latitudes of the SH and to $30 \%$ over the rest of the maritime area by the assimilation.

Black carbon and organic matter AOD were reduced in CAMSiRA over tropical Africa where biomass burning is the largest source on the global scale, and the CO biomass burning emissions were also too high. The black carbon and organic matter AOD values were higher in CAMSiRA away from the sources where values are generally low. The dif- ferences in black carbon and organic matter AOD between CAMSiRA and the CR showed a strong reduction directly over the areas of intense fire emission in tropical Africa and the boreal forest of the $\mathrm{NH}$ and an increase in the adjacent outflow regions. This could indicate that the GFAS emissions, as in the case of CO (see Sect. 3.1), were too high but the atmospheric residence times of the aerosol species were too short.

Compared to CAMSiRA, MACCRA AOD values were up to $50 \%(-0.2$ to -0.3$)$ lower in the desert-dust-dominated areas over the Sahara and central Asia. The largest differences over northern Africa occurred in JJA and MAM and are an indication that MODIS AOD retrievals are not available over these regions because of their bright surface (Hsu et al., 2013). The AOD values of CAMSiRA that are higher than MACCRA in the desert dust regions might be an improvement since Cuevas et al. (2015) reported a general underestimation with respect to the AErosol RObotic NETwork (AERONET) observations in the dust-dominated regions of MACCRA.

Conversely, sea salt AOD over all oceans was much higher in MACCRA than CAMSiRA and it even exceeded the high sea salt AOD of the CR. Despite the higher sea salt AOD, the total AOD of MACCRA over the oceans was lower than in CAMSiRA because of the overall smaller sulfate AOD in maritime regions.

In the regions of boreal fire emissions, MACCRA AOD was lower during the JJA fire season as well as in the South American fire season in SON. For the rest of the globe, CAMSiRA was about 0.05 lower than MACCRA, which meant a large relative reduction $(>50 \%)$, in particular over the oceans.

The differences between MACCRA and CAMSiRA can mainly be explained with the changes in the underlying mod- 

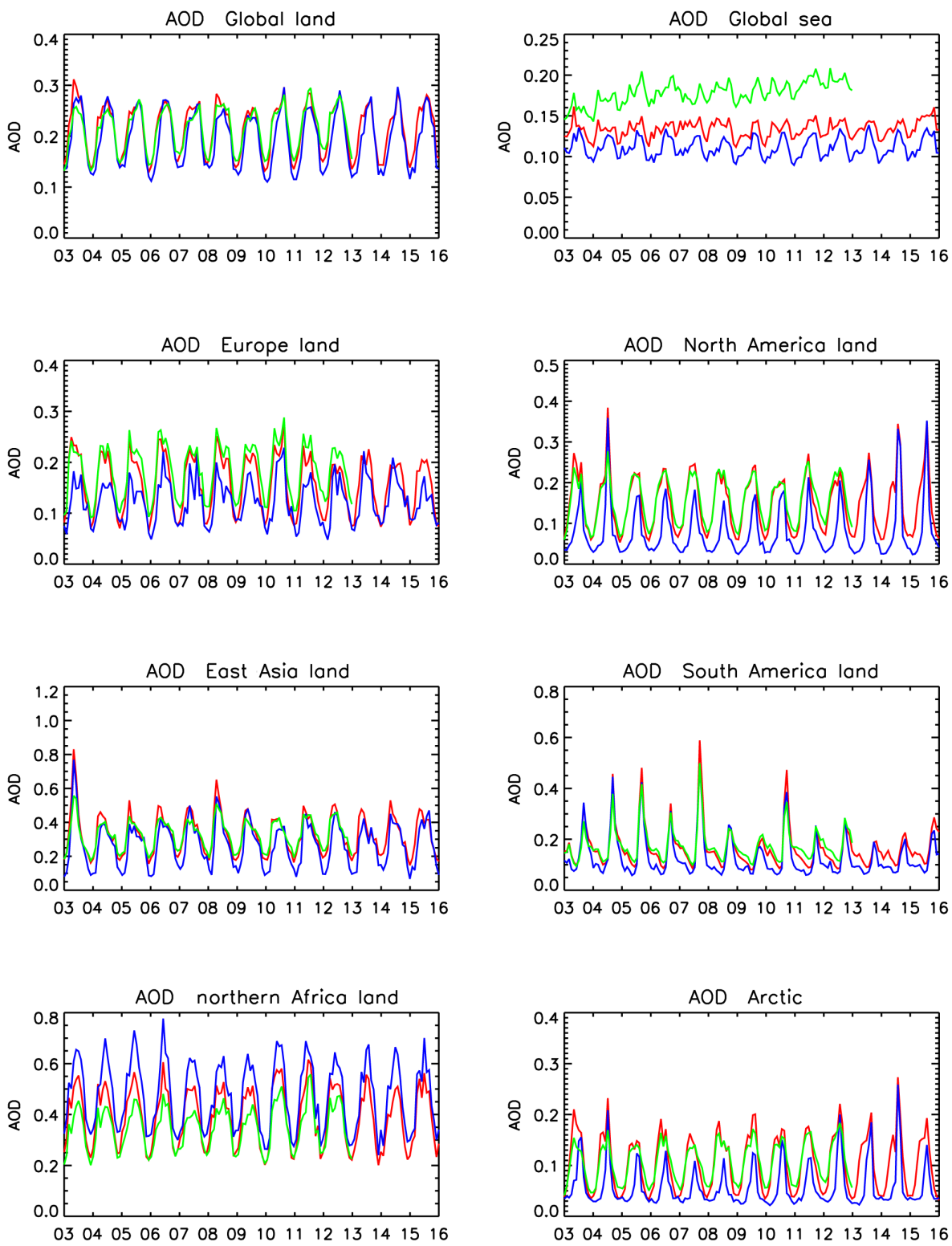

Figure 10. Time series of monthly mean AOD over the whole globe (land or sea points) and for different regions (see Table 3 ) for the period 2003-2015 from CAMSiRA (red), the CR (blue) and MACCRA (green, 2003-2012).

elling approach and the emissions since the same MODIS AOD retrievals were assimilated in both reanalyses. Differences in the background error statistics may have contributed to the differences between MACCRA and CAMSiRA, particularly in the high latitudes.

Figure 9 shows a zonally averaged cross section of the total aerosol mixing ratio of CAMSiRA and its relative differences compared to the CR and MACCRA. The highest zonal average occurred over the Southern Ocean because of the continuous sea salt production and over the latitudes of the regions with large desert dust and anthropogenic emissions. Despite the mostly higher AOD values, CAMSiRA had lower mass mixing ratios than the CR throughout the tro- posphere with the largest relative differences occurring over the SH mid-latitudes and in the region of intense convection in the tropics. This is related to a change in the speciation, which was discussed in Sect. 4.1. CAMSiRA had up to $90 \%$ higher values in the stratosphere and Antarctica. The higher aerosol mixing ratios of CAMSiRA in the upper troposphere were dominated by sulfate aerosol. In relative terms, MACCRA mixing ratios were considerably higher than CAMSiRA throughout the troposphere with the exception of the $\mathrm{NH}$ extratropical mid-troposphere, which was caused by the lower dust emissions in MACCRA, and the SH and tropical stratosphere, which was caused by high sulfate concentrations in CAMSiRA. 

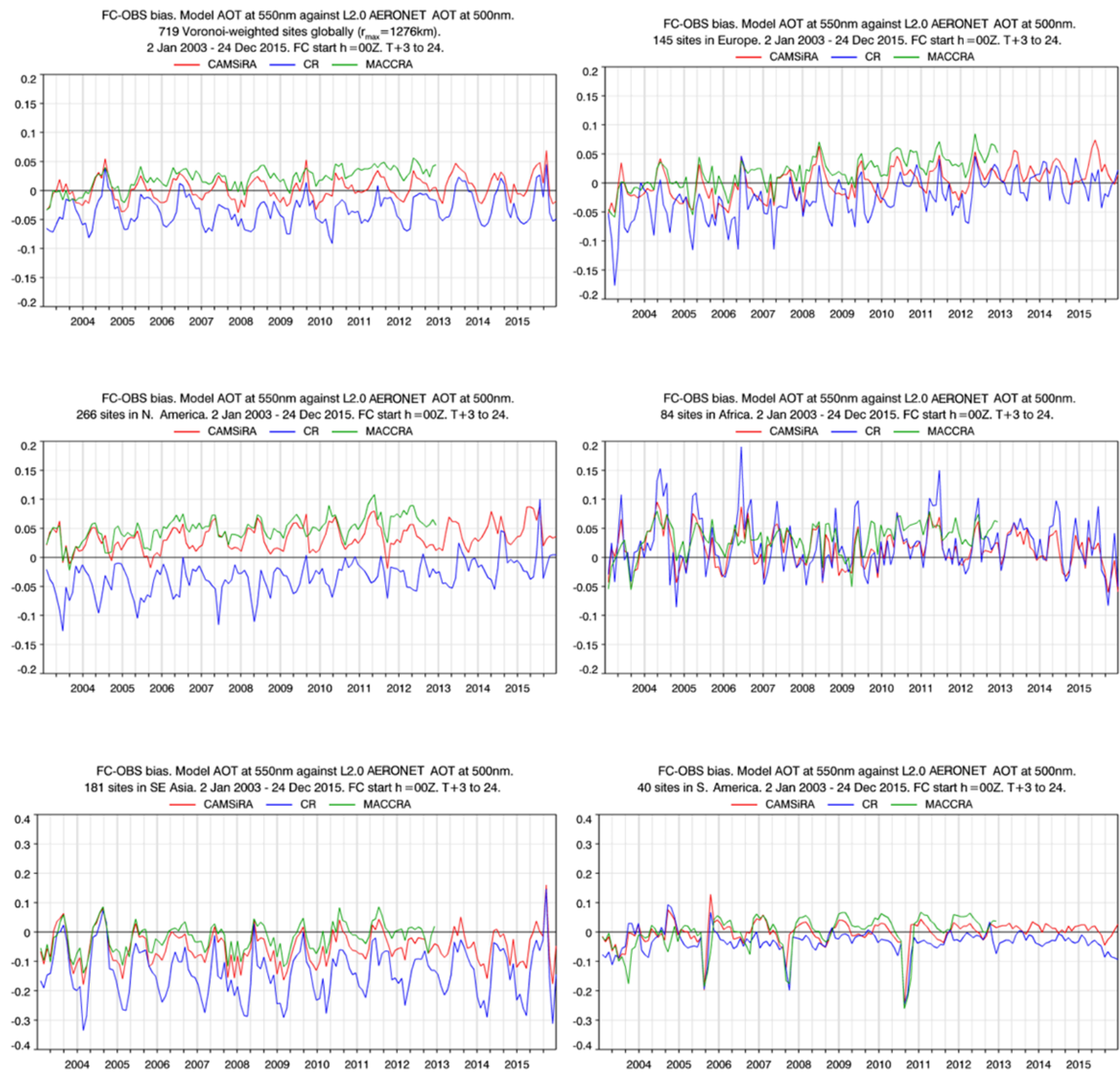

Figure 11. Time series of monthly mean bias of AERONET AOD observations averaged over the whole globe (top left), Europe (top right), North America (middle left), Africa (middle right), South East Asia (bottom left), and South America (bottom right) for CAMSiRA (red), the CR (blue), and MACCRA (green).

\subsection{Interannual variability of AOD}

Figure 10 shows time series of average AOD from CAMSiRA, the CR and MACCRA for different regions. To better distinguish the impact of sea salt, the regional AOD is averaged over land points only. The global average AOD time series are shown separately for land and sea points.

The CR and CAMSiRA did not have any significant $(95 \%$ confidence level) trends in AOD over the whole globe or any of the considered regions. There was a good agreement between CAMSiRA and the CR in their interannual variability with respect to specific years with higher maxima over South and North America as well as over Maritime South East Asia and northern Africa. This demonstrates that despite biases the model was able to reproduce the variability related to fire emissions and wind-driven desert dust suspension. A large relative difference between the $\mathrm{CR}$ and CAMSiRA occurred in the Arctic. The CAMSiRA and MACCRA AOD values were almost twice as high as the CR and had a much more pronounced seasonality. 

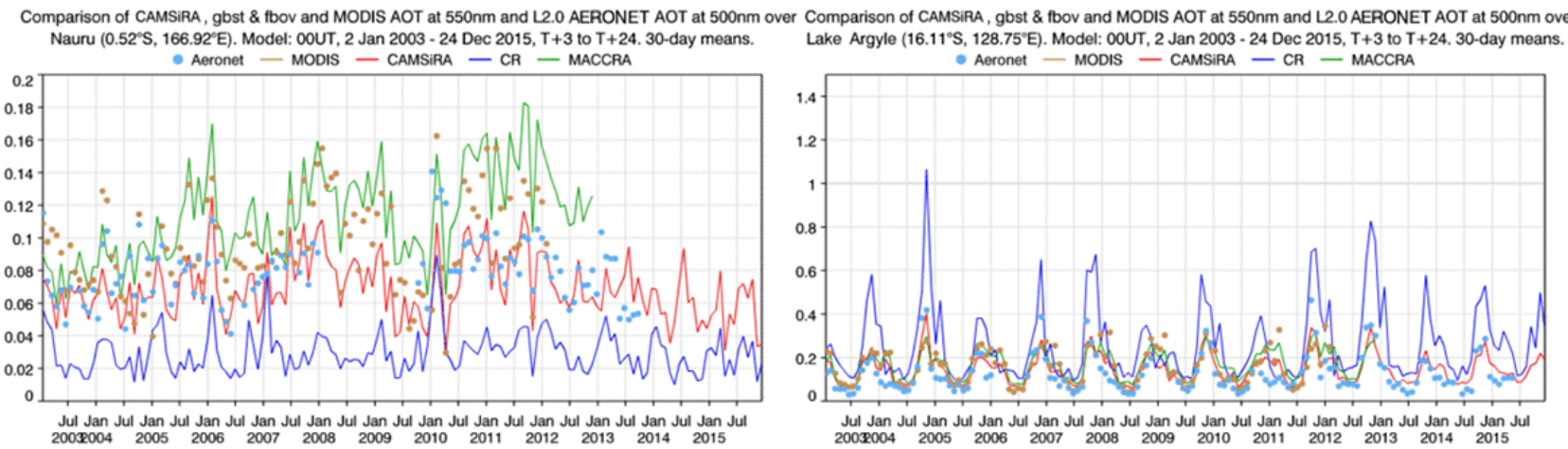

Figure 12. Time series of monthly mean AOD from AERONET observations (light blue dots), MODIS retrievals (brown dots) and from CAMSiRA (red), the CR (blue) and MACCRA (green) at Nauru (left) and Lake Argyle (right).

In contrast to the lack of significant trends in the CR and CAMSiRA, MACCRA had a significant positive trend over all sea points, leading to an increase over 10 years that was as large as the seasonal variation over all sea points. Averaged over all land points, the seasonal variation is much larger than over sea. The agreement in AOD in the monthly means time series was generally high, but MACCRA also showed a significant increasing trend, which was not present in the other two data sets. Most of this trend in MACCRA was caused by dust AOD, which increased by $3.7 \% \mathrm{yr}^{-1}$, and sea salt AOD, which increased by $1.7 \% \mathrm{yr}^{-1}$ over sea points. We consider this trend in MACCRA as spurious. It is likely caused by an accumulation of aerosol mass, which could not be corrected for by the assimilation. A reason for the mass accumulation could be the fact that the MACCRA model did not apply a global mass fixer.

Even if the CR and CAMSiRA did not show significant trends in total AOD, sulfate AOD of CAMSiRA increased significantly by $0.55 \% \mathrm{yr}^{-1}$ and both the CR and CAMSiRA had a positive trend in sea salt AOD of $0.3 \% \mathrm{yr}^{-1}$. This suggests an artificial accumulation of sulfate by the assimilation because the emissions for the aerosol sulfate precursor $\left(\mathrm{SO}_{2}\right)$ were constant. The increase in sulfate was likely caused by underestimated loss processes for sulfate and $\mathrm{SO}_{2}$ in the free and upper troposphere away from the emissions sources. The relative increase in sulfate with respect to the other aerosol species could not be corrected for by the assimilation of AOD.

\subsection{Evaluation with AERONET AOD observations}

The AOD at $550 \mathrm{~nm}$ was evaluated with observations of the AERONET network. The AERONET is a network of about 400 stations measuring spectral AOD aerosol with groundbased sun photometers (Holben et al., 1998). The stations are mostly located over land, with a high number of stations situated in North America and Europe. The global number of stations contributing observations for the evaluation increased from about 60 in 2003 to about 250 in 2014 before it was largely reduced to only a couple of stations at the end of 2015.

Figure 11 shows time series of the monthly biases of CAMSiRA, MACCRA and the CR for the globe and different regions. Over North America, an area with a high density of AERONET stations, the CR underestimated AOD by 0.05 on average. Conversely, the two analyses overestimated AOD by about 0.02 , but CAMSiRA has marginally smaller biases than MACCRA. In South America a similar pattern was found. However, the average underestimation of the CR and overestimation of CAMSiRA and MACCRA were -0.05 and 0.05 respectively. The overestimation of CAMSiRA and MACCRA and the underestimation of the CR over North America leads to the conclusion that the assimilated MODIS retrievals were biased higher compared with the AERONET observations in this region, as also pointed out in Levy et al. (2010). The underlying model does not seem to be the cause of the overestimation in CAMSiRA.

Over Europe, CAMSiRA had the smallest biases and MACCRA slightly overestimated, whereas the CR underestimated the observations. The bias of the $\mathrm{CR}$ was -0.07 at the beginning of the period and almost zero at the end. More research is needed to understand this trend in the bias, which is also apparent in CAMSiRA and MACCRA, but it might be caused by the reduced number of available stations.

MACCRA had the lowest biases over South East Asia because of small biases in northern India and Indochina. In this area, as almost everywhere, MACCRA was higher than CAMSiRA and the CR. CAMSiRA underestimated the observations in this region by about 0.05 . The underestimation by the CR was bigger and showed a pronounced seasonal cycle. The largest negative biases occurred at the time of the seasonal minimum in DJF.

The performance for desert dust and sea salt was more difficult to evaluate in a robust way with AERONET stations because only few stations are available in these regions. The average bias over Africa showed a strong reduction by the assimilation of the CR peak values, which occurred because of desert dust outbreaks. A good example of the success- 

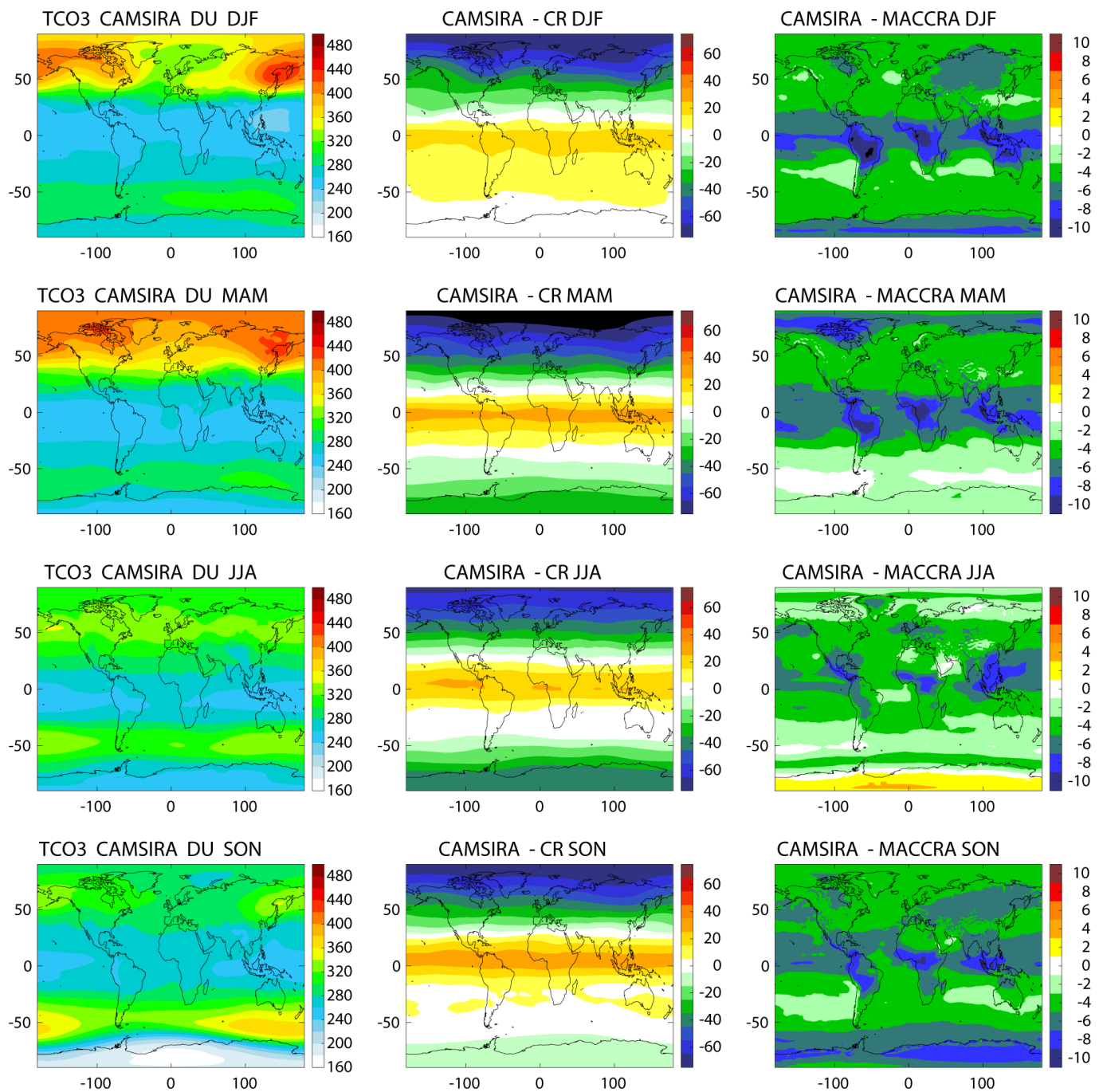

Figure 13. Seasonally averaged TC ozone (DU) from CAMSiRA (left), difference between CAMSIRA and the CR (middle), and difference between CAMSiRA and MACCRA (right, 2003-2012, different scale) for the seasons DJF (row 1), MAM (row 2), JJA (row 3), and SON (row 4).

ful reduction of dust by the assimilations was Lake Argyle $\left(16.11^{\circ} \mathrm{S}, 128.75^{\circ} \mathrm{E}\right)$ in Australia (Fig. 12, left).

The AERONET AOD observations over the oceans generally show an overestimation of all runs, in particular for MACCRA. The bias of the MODIS retrievals with respect to AERONET (Shi et al., 2011) may be a reason for this overestimation. The comparison with AOD observations at Mauna Loa Station $\left(19.54^{\circ} \mathrm{N}, 155.58^{\circ} \mathrm{W}\right.$, not shown) in the eastern Pacific suggests that the low AOD values of the CR reproduced the observations best, although still overestimating them. At Nauru Station $\left(0.52^{\circ} \mathrm{S}, 166.9^{\circ} \mathrm{E}\right.$; Fig. 12 , right $)$ in the western Pacific, CAMSiRA matches the observations well, whereas the CR underestimated them and MACCRA overestimated them.

\section{Stratospheric ozone}

The experience from the assimilation of TC and stratospheric profile retrievals (Inness et al., 2013; van der A et al., 2015; Levefer et al., 2015) shows that these observations are sufficient to constrain stratospheric ozone in the reanalysis. Because almost the same ozone retrievals were assimilated in CAMSiRA as in MACCRA (see Table 2), most of the differences in the ozone analyses can be attributed to differences in the ozone simulation of the assimilating model. For CAMSiRA, the Cariolle parameterization (Cariolle and Teyssèdre, 2007) of stratospheric ozone chemistry and the chemical mechanism CB05 for the troposphere were used. The tropospheric and stratospheric chemical scheme of the MOZART CTM (Kinnison et al., 2007) was used for MACCRA. 

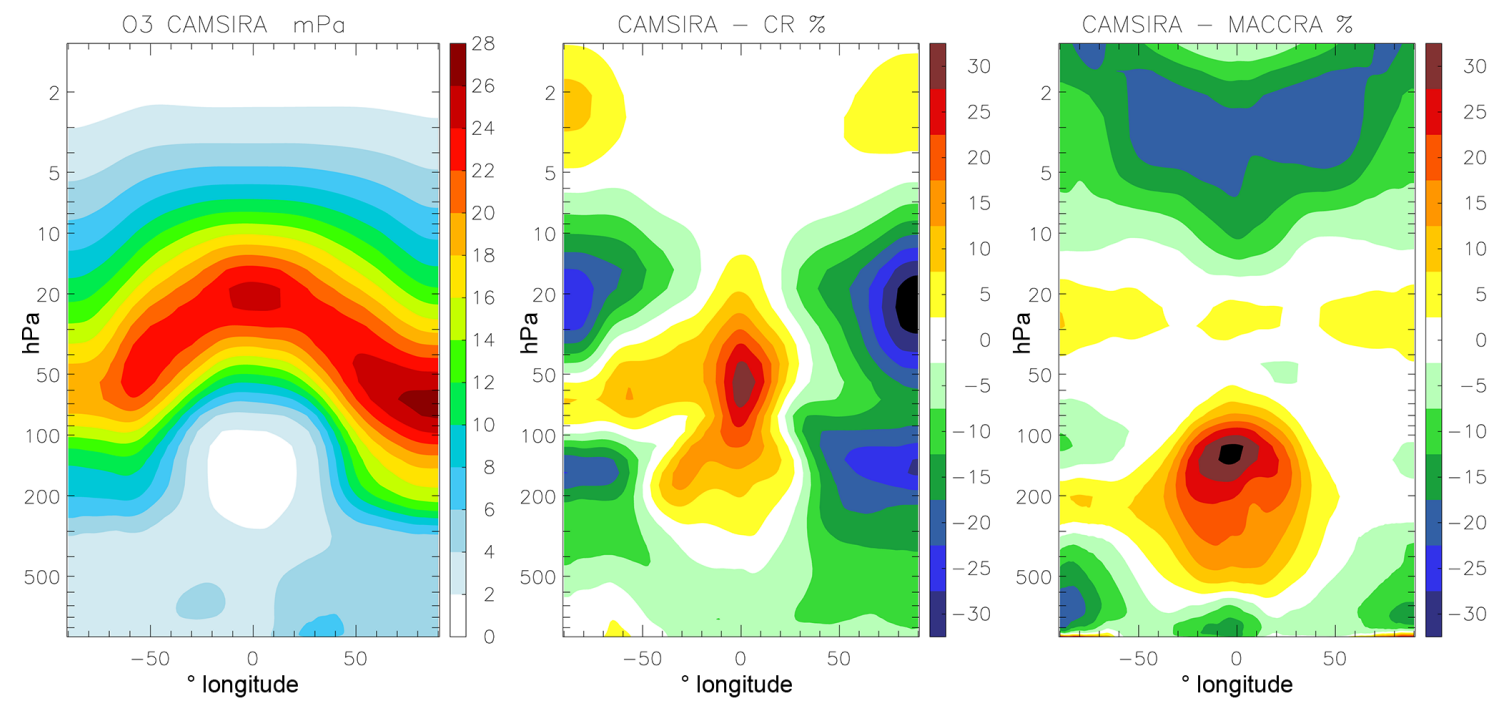

Figure 14. Zonally averaged ozone partial pressure (mPa) of CAMSiRA (2003-2015, left) and relative difference (\%) compared with the CR (2003-2015, middle) and MACCRA (2003-2012).

\subsection{Spatial patterns of TC ozone}

Figure 13 shows the seasonal average TC ozone from CAMSiRA and the difference between this data set and the CR and MACCRA. The differences between CAMSiRA and the $\mathrm{CR}$ had a meridional pattern. The assimilation in CAMSiRA increased the total ozone columns in the tropics and subtropics by up to $25 \mathrm{DU}(8 \%)$ and it decreased them by $50-70 \mathrm{DU}$ in the NH middle and high latitudes. The largest reduction occurred in DJF and MAM. Over Antarctica the assimilation also led to lower values in austral winter (JJA), when TC ozone was reduced by up to $30 \mathrm{DU}$.

CAMSiRA was about 3-5 DU (1\%) lower than MACCRA across the globe. Larger differences of up to 10DU (2\%) were located mainly over tropical land areas. Their shape suggest that they were partially caused by differences in tropospheric ozone (see Sect. 6.1). On the seasonal scale, CAMSiRA was about 10 DU lower over Antarctica and the Arctic in the spring seasons MAM and SON respectively.

Figure 14 shows the average ozone partial pressure cross section of CAMSiRA and the relative differences with the CR and MACCRA. The tropospheric part of the figure will be discussed in Sect. 6.1. The overestimation of the CR in the high latitudes of the $\mathrm{NH}$ and $\mathrm{SH}$ was located predominately in the middle and upper stratosphere at around $20 \mathrm{hPa}$. The underestimation in the tropics had the largest values at around $50 \mathrm{hPa}$.

In the lower and middle stratosphere, i.e. from 70 to $20 \mathrm{hPa}$, CAMSiRA and MACCRA differed by less than $5 \%$. Larger differences occurred above $10 \mathrm{hPa}$ where MACCRA was up to $30 \%$ higher than CAMSiRA, which will be discussed in more detail in Sect. 5.5.

\subsection{Interannual variability of TC ozone}

Figure 15 shows area-weighted averages of the monthly TCs for the whole globe, the tropics, southern and $\mathrm{NH}$ midlatitudes, Antarctica and the Arctic.

In the tropics, CAMSiRA had a significant $(95 \%$ confidence level) trend of $+0.15 \% \mathrm{yr}^{-1}$. Although the period of 13 years is too short to estimate total ozone trends with respect to ozone recovery, it is worth noticing that the number is in good agreement with the estimate of the ozone trend for the period 1995-2013 by Coldewey-Egbers et al. (2014, see their Fig. 1), which varies in the tropics between 0.5 to $1.5 \%$ per decade. No trends could be found in the CR, probably because the climatological approach applied in the Cariolle scheme is not able to simulate long-term trends. The tropical trend in MACCRA was $0.25 \% \mathrm{yr}^{-1}$, which seems too high, and there was also a significant trend in the SH mid-latitudes of $0.65 \% \mathrm{yr}^{-1}$.

The seasonal range, i.e. the difference between annual maximum and minimum, of TC ozone in CAMSiRA increased from $10 \mathrm{DU}$ in the tropics to up $150 \mathrm{DU}$ in the Arctic and $100 \mathrm{DU}$ in Antarctica. As already mentioned in Sect. 5.1, the CR was $20 \%$ higher than CAMSiRA in NH mid-latitudes and Antarctica. However, the interannual variability agreed reasonably well between CAMSiRA and the CR in the southern and middle hemispheric high and mid-latitudes. For example, the reduced Arctic ozone spring in 2011 (Manney et al., 2011) and the year-to-year differences in mid-latitudes found in CAMSiRA were well reproduced by the CR.

The ozone hole in austral spring is the most important feature of seasonal variability over Antarctica. Despite its simplicity, the Cariolle scheme in the CR reproduced the ozone loss during the ozone hole periods with respect to minimum 

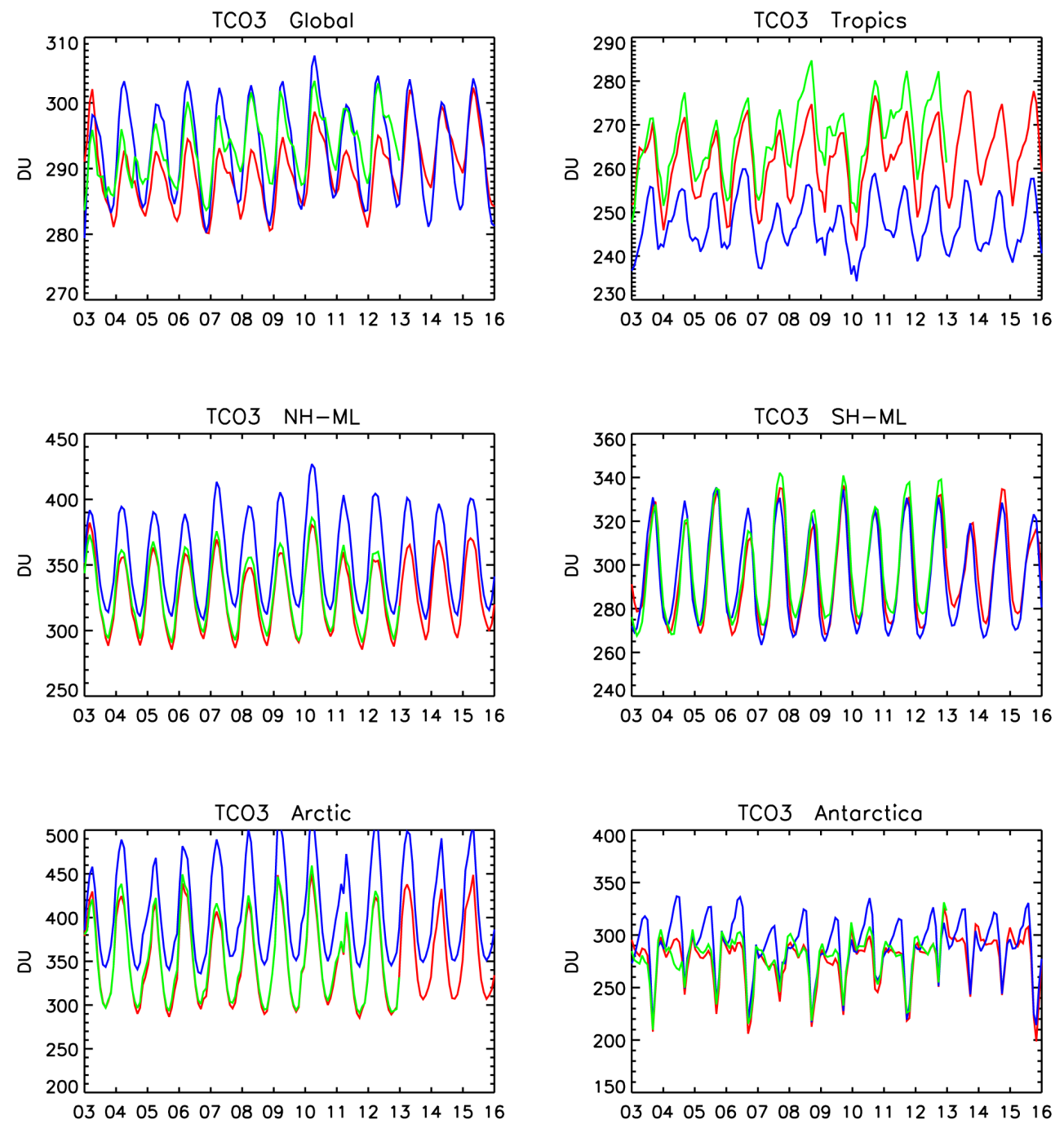

Figure 15. Monthly ozone TC (DU) area averaged over different regions (see Table 3) from CAMSiRA (black), the CR (blue) and MACCRA (green) for 2003-2015.

value and interannual variability of TC ozone very well without assimilating any observations. The years with the deepest ozone holes (2015, 2003 and 2006) and with the shallowest ozone holes (2011,2013 and 2004) were the same in CAMSiRA and the CR. Conversely, the CR overestimated the average TC ozone during the Antarctic winter by about $30 \mathrm{DU}$.

There was generally good agreement between CAMSiRA and MACCRA over all parts of the globe, but MACCRA was on average about 5-10 DU (2\%) higher than CAMSiRA. The strong positive trend of MACCRA in the tropics together with a significant positive trend in the SH mid-latitudes led to increasing differences in the global average at the end of the MACC period. A larger difference between MACCRA and CAMSiRA occurred in winter (JJA) over Antarctica, when MACCRA was up to 25 DU lower than CAMSIRA. The depth of the ozone hole was slightly deeper in CAMSiRA than in MACCRA.

\subsection{Evaluation with total ozone retrievals from Dobson sun photometers}

Ozone TCs are observed from the ground with Dobson, Brewer, point filter and Fourier transform infrared (FTIR) spectrometers. The Dobson instruments provide the longest and best spatial coverage and we use this data set to evaluate the TC of CAMSiRA, MACCRA and the CR. The Dobson instruments of the World Ozone and Ultraviolet Radiation Data Centre (WOUDC) network are well calibrated and their precision is $1 \%$ (Basher, 1982). Factors that influence the accuracy of the Dobson spectrometer are the temperature dependency of the ozone absorption coefficient and the presence of $\mathrm{SO}_{2}$.

Figure 16 shows time series of the monthly bias against the Dobson photometer observations for different regions. Observations of about 50-60 stations were available until 2013, 

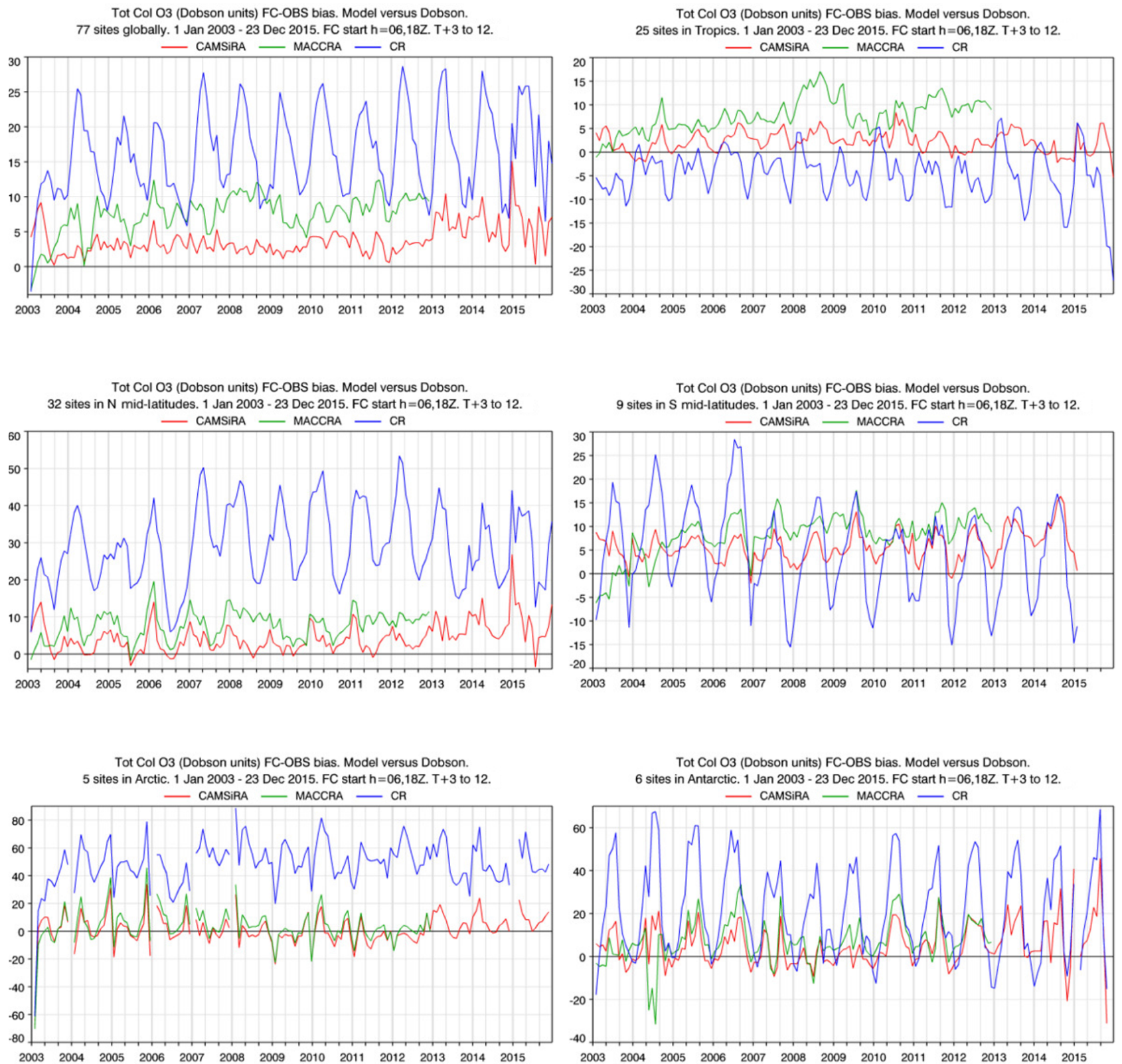

Figure 16. Time series of monthly mean bias in DU against WOUDC Dobson sun photometers for the globe (top left), the tropics (top right), NH mid-latitudes (middle left), SH mid-latitudes (middle right), the Arctic (bottom left) and Antarctica (bottom right) for CAMSiRA (red), the CR (blue) and MACCRA (green).

but the number of stations dropped steadily to about 10 stations at the end of 2015. CAMSiRA overestimated the observations in the tropics and the mid-latitudes of both hemispheres by $2 \mathrm{DU}$ on average, whereas the mean bias of MACCRA was about 5 DU larger. In Antarctica and the Arctic the biases showed a more pronounced seasonal cycle, mostly between -10 and $20 \mathrm{DU}$.

The biases of MACCRA increased in the tropics and the SH mid-latitudes from 2003 to 2008, whereas CAMSiRA and $\mathrm{CR}$ did not show an obvious change in the biases until
2012. The variability of the bias of CAMSiRA was amplified at the start of 2013 in the NH. Since this change in the bias is not seen at individual stations until the end of 2015, we conclude that the change is caused by the reduction in the number of stations available after 2013. It is not caused by the change of the assimilated MLS data set version (from V2 to V3.4) because this already took place at the beginning of 2013 (see Table 2).

The biases of the CR were much larger than the ones of CAMSiRA, and they had a strong seasonal cycle. In the 

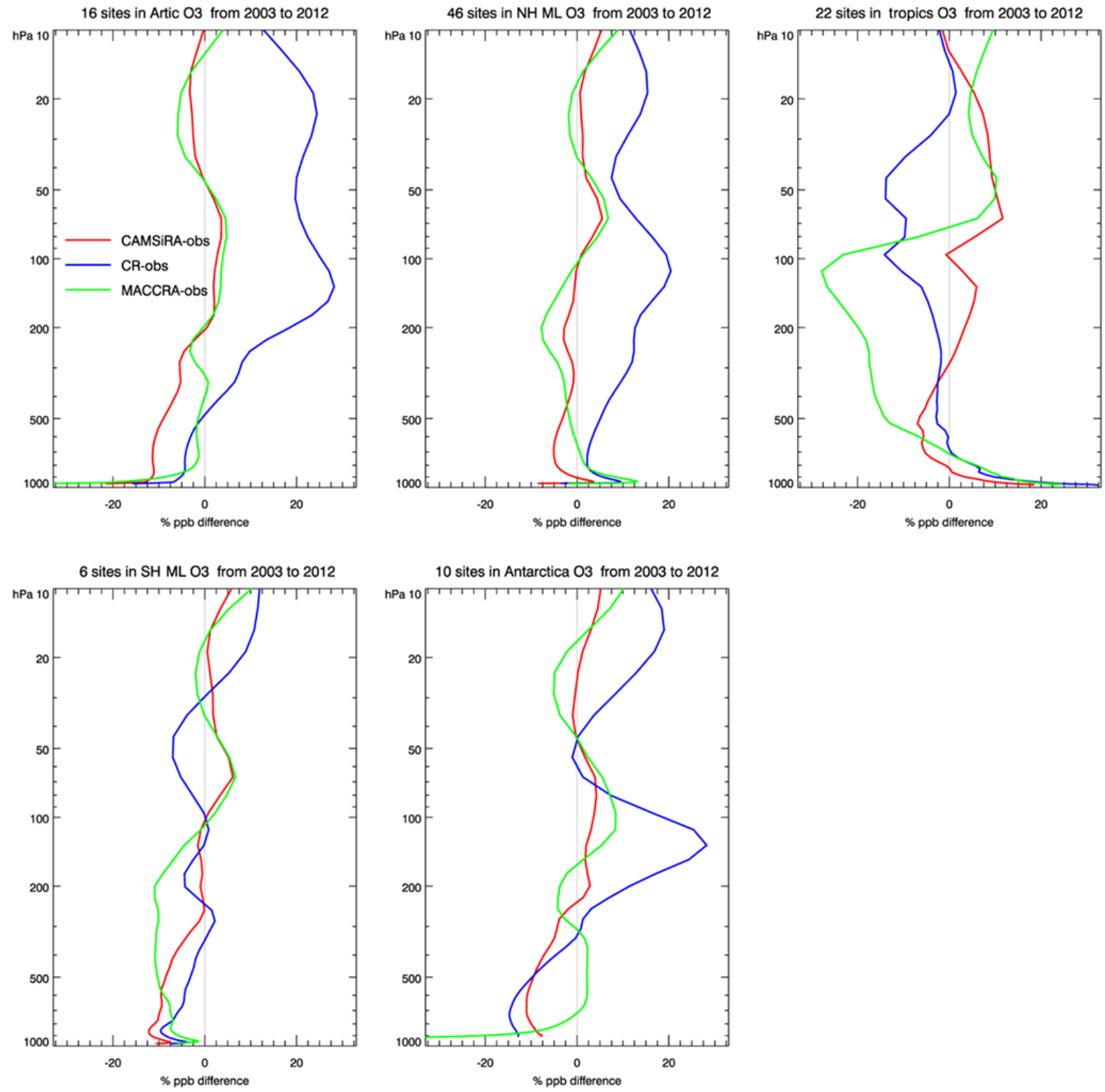

Figure 17. Mean relative bias of CAMSiRA (red), MACCRA (green) and the CR (blue) compared with ozone sondes in the Arctic (top left), NH mid-latitudes (top middle), tropics (top right), SH mid-latitudes (bottom left) and Antarctica (bottom middle) for the period $2003-2012$.

tropics the CR underestimated the TC by $10 \mathrm{DU}$ in DJF and $0 \mathrm{DU}$ in MAM. The NH biases were positive and varied between 20 and $50 \mathrm{DU}$ and in the Arctic between 20 and 70 DU. Over Antarctica the CR overestimated the observation by 40 $60 \mathrm{DU}$ in JJA, but the bias was close to zero or even slightly negative during the time of the ozone hole.

\subsection{Evaluation with ozone sondes in the stratosphere}

The global network of ozone sondes is the most comprehensive independent data set for the evaluation of the threedimensional ozone fields from the surface to about $10 \mathrm{hPa}$, which is the level with the highest stratospheric ozone vol- ume mixing ratios. The observation error of the sondes is about $\pm 5 \%$ in the range between 200 and $10 \mathrm{hPa}$ and $-7-$ $17 \%$ below $200 \mathrm{hPa}$ (Beekmann et al., 1994; Komhyr et al., 1995; Steinbrecht et al., 1996). The number of soundings varied for the different stations used here. Typically, the sondes are launched once a week but in certain periods such as during ozone hole conditions launches are more frequent. Sonde launches are carried out mostly between 9 and $12 \mathrm{~h}$ local time. The global distribution of the launch sites is even enough to allow meaningful averages over larger areas such as North America, Europe, the tropics, the Arctic and Antarctica. 

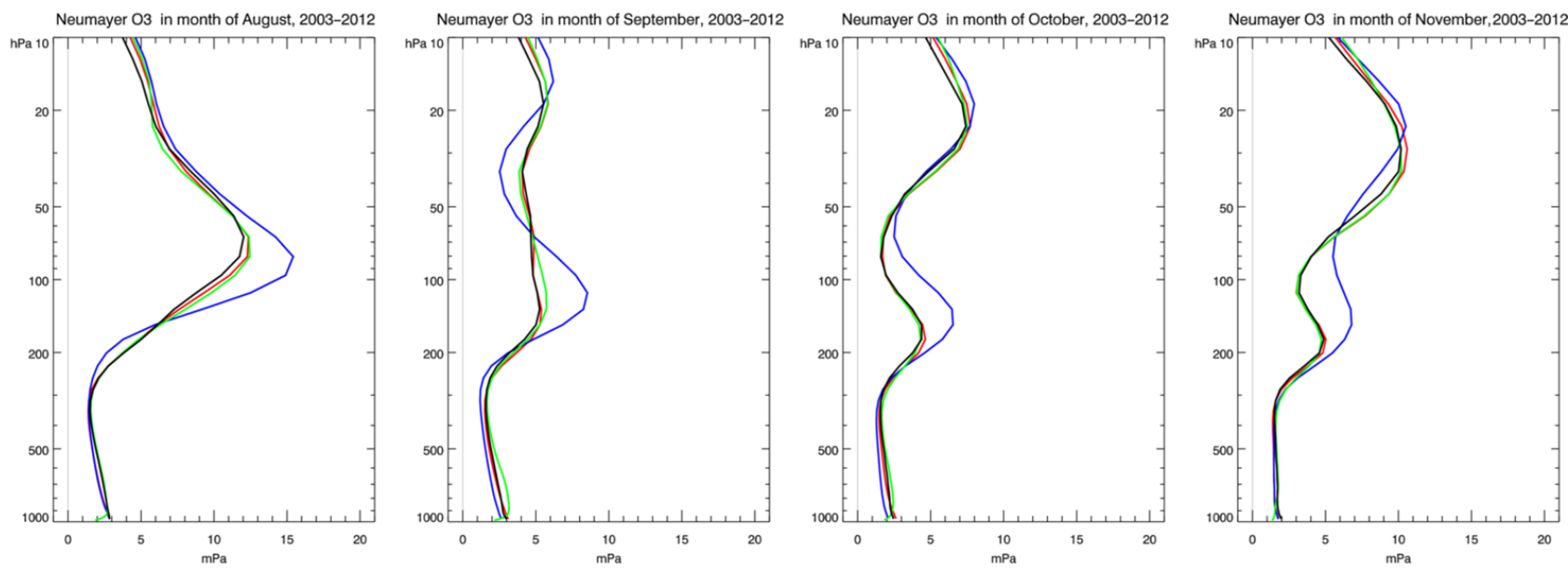

Figure 18. Monthly mean ozone profiles (mPa) at Neumayer Station from ozone sondes of CAMSiRA (red), MACCRA (green) and the CR (blue) for August to November (2003-20012).

Figure 17 shows the profiles of the relative biases of CAMSiRA, MACCRA and the CR over the tropics, Antarctica, the Arctic and the $\mathrm{NH}$ and $\mathrm{SH}$ mid-latitudes for the period 2003-2012. All available observations were included in the average.

In the tropics, CAMSiRA had a relative bias of mostly below $10 \%$ in most levels of the stratosphere. MACCRA strongly underestimated the ozone sondes (up to $30 \%$ ) in the lower stratosphere, but the relative bias of MACCRA was similar or slightly smaller than the bias of CAMSiRA in most parts of the stratosphere, i.e. in the pressure range from 70 to $20 \mathrm{hPa}$. The CR underestimated the ozone sondes by up to $20 \%$ in the stratosphere up to $30 \mathrm{hPa}$. The largest underestimation of the CR occurred in the lower and mid-stratosphere, where the maximum in ozone partial pressure is located. In the upper stratosphere above $20 \mathrm{hPa}$, where the maximum of ozone volume mixing ratio is located, the relative biases of all data sets were smaller than in the levels below. The CR had almost no bias, whereas MACCRA overestimated by up to $10 \%$.

Over the Arctic and NH mid-latitudes, CAMSiRA and MACCRA agreed well with the sondes in the whole stratosphere, with relative biases below $5 \%$. The absolute biases of CAMSiRA were slightly smaller than the biases of MACCR, in particular in the lower stratosphere and upper troposphere. The CR overestimated the ozone observations by up to $25 \%$ in the stratosphere and upper troposphere over the Arctic and up to $20 \%$ in the NH mid-latitudes. The relative biases of the CR tended to be slightly smaller in the mid-stratosphere $(50 \mathrm{hPa})$ than in the upper and lower stratosphere.

Over SH mid-latitudes and Antarctica, the annual biases in the stratosphere were slightly smaller in CAMSIRA than in MACCRA, but for both reanalyses they were below $10 \%$. As over the Arctic, the absolute tropospheric biases, with the exception of the surface values, were smaller in MACCRA since CAMSiRA showed an underestimation of about $10 \%$. The CR had a stronger underestimation in the lower and upper stratosphere.

Since the process of the ozone-hole formation cannot easily be demonstrated with annual means, Fig. 18 shows the monthly mean profile from August to November over Neumayer Station $\left(70.7^{\circ} \mathrm{S}, 8.3^{\circ} \mathrm{W}\right)$. The two reanalyses agreed very well with the observations: vertical level and magnitude of the ozone profile at the end of the austral winter in August, the ozone depletion in September and October, and the closure of the ozone hole starting in the upper stratosphere were well captured because of the assimilation of TC and limb-sounder profiles.

In contrast, the $\mathrm{CR}$ showed a strong overestimation in $\mathrm{Au}$ gust in the middle and lower stratosphere. Ozone in the upper stratosphere in September was underestimated in the CR because of an exaggerated depletion, whereas ozone was overestimated in the lower stratosphere. In the following months the CR ozone remained too high in the lower stratosphere and too low in the upper troposphere, but the resulting TCs matched the observations in a reasonable way (see Fig. 16)

\subsection{Evaluation with the GOZCARDS ozone product in the upper stratosphere}

Ozone sondes do not provide accurate measurements above $10 \mathrm{hPa}$. The ozone bias profiles shown in Fig. 17 indicate higher values of MACCRA in the upper stratosphere and mesosphere, i.e. from above $10 \mathrm{hPa}$ to the model top of $0.1 \mathrm{hPa}$. Although the ozone mass in this region is relatively small, the high values of the mixing ratios have a large impact on the radiative transfer and the associated heating rates. To investigate the biases in that region we used the GOZCARDS (Global OZone Chemistry And Related trace gas Data records for the Stratosphere) product (Froidevaux et al., 2015). It consists of merged SAGE I, SAGE II, HALOE, 

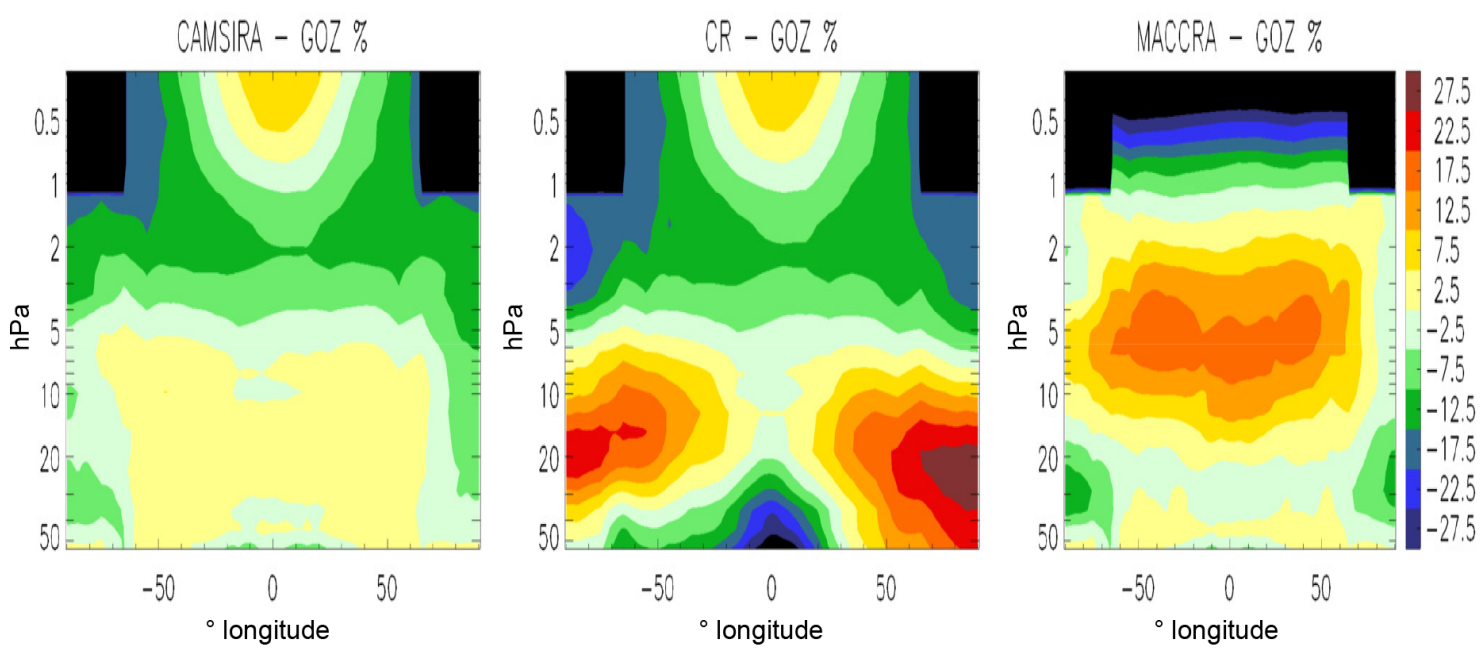

Figure 19. Cross sections $(50-0.3 \mathrm{hPa})$ of the relative biases of zonally averaged ozone (\%) of CAMSiRA (left), the CR (middle) and MACCRA (right) compared with the GOZCARDS product (GOZ) for the period 2005-2012.

UARS and Aura MLS, and ACE-FTS data from late 1979 to 2012. SAGE II is used as the primary reference in the merging procedure for the instruments. For most of the CAMSiRA period, i.e. from 2004 onwards, Aura MLS and ACE-FTS are the dominating instruments in the upper stratosphere. Tegtmeier et al. (2013) showed that ozone retrievals from various instruments show a considerable spread in the upper stratosphere. ACE-FTS is biased high $(5-10 \%)$ above $10 \mathrm{hPa}$ and biased low (5-10\%) below $10 \mathrm{hPa}$ compared with the median of various retrievals.

Figure 19 shows cross sections of the GOZCARDS product and relative bias of CAMSiRA, MACCRA and the CR in the vertical range from 50 to $0.3 \mathrm{hPa}$. In the region from 10 to $5 \mathrm{hPa}$, MACCRA had a positive bias of $10-15 \%$ in the tropics and mid-latitudes, which has already been reported in Inness et al. (2013). About half of the 10 DU higher TCs in MACCRA compared to CAMSiRA were caused by this overestimation in the levels above $10 \mathrm{hPa}$. The biases of CAMSiRA in that region were smaller and vary between 2.5 and $-2.5 \%$. CAMSiRA underestimated the GOZCARDS data between 5 and $1 \mathrm{hPa}$ by up to $7 \%$, whereas MACCRA slightly overestimated. In the lower mesosphere MACCRA underestimated the ozone concentrations by up to $30 \%$.

The CR had very similar biases to CAMSiRA above $5 \mathrm{hPa}$ in the tropics and mid-latitudes. This means that the assimilation of observations already had little influence in this region even if no increments were added during the CAMSiRA assimilation above $1 \mathrm{hPa}$. Below $10 \mathrm{hPa}$ the cross section of the bias shows the already-discussed strong overestimation of the $\mathrm{CR}$ in the middle and higher latitudes, which was largest in relative terms at around $20-15 \mathrm{hPa}$, and the underestimation in the tropics, which was largest at around $50 \mathrm{hPa}$.

\section{Tropospheric ozone}

Correcting tropospheric ozone by the assimilation of TC and stratospheric ozone profiles remains a challenge because the observations are dominated by the higher stratospheric mixing ratios (Wagner et al., 2015). The modelled ozone fields as well as the specification of the vertical background error correlation therefore have a large impact on the analysed tropospheric ozone fields (Inness et al., 2015).

\subsection{Spatial patterns of ozone at $850 \mathrm{hPa}$}

We focus the discussion of the seasonal spatial patterns of monthly mean tropospheric ozone mole fraction to the $850 \mathrm{hPa}$ pressure level values, but we also discuss tropospheric ozone at 500 and $200 \mathrm{hPa}$ in Sect. 6.2 and comparisons with ozone sondes for different tropospheric layers in Sect. 6.3. Figure 20 shows the seasonal means of CAMSiRA and the differences compared with the CR and MACCRA at $850 \mathrm{hPa}$. Extratropical NH ozone values of CAMSiRA were mostly in the range from 35 to $55 \mathrm{ppb}$. The maximum was MAM, when values were about $20 \mathrm{ppb}$ higher than the seasonal minimum in DJF. Regional maxima of over $60 \mathrm{ppb}$ were situated over East Asia and the Arabian Peninsula. JJA was the season when the highest values occurred over the areas of the regional maxima. In this season additional regional maxima occurred over tropical Africa. The $\mathrm{SH}$ values were generally below $35 \mathrm{ppb}$. The seasonal maximum was in austral spring (SON) and the minimum was in austral summer and late autumn (SON).

The CR was about 2-4 ppb higher than CAMSiRA in most parts of the globe. Only in the higher latitudes of the $\mathrm{SH}$ as well as over the biomass burning regions in Africa, South America and Maritime South East Asia, was CAMSiRA up to $4 \mathrm{ppb}$ lower than the $\mathrm{CR}$. The biggest large-scale reduc- 

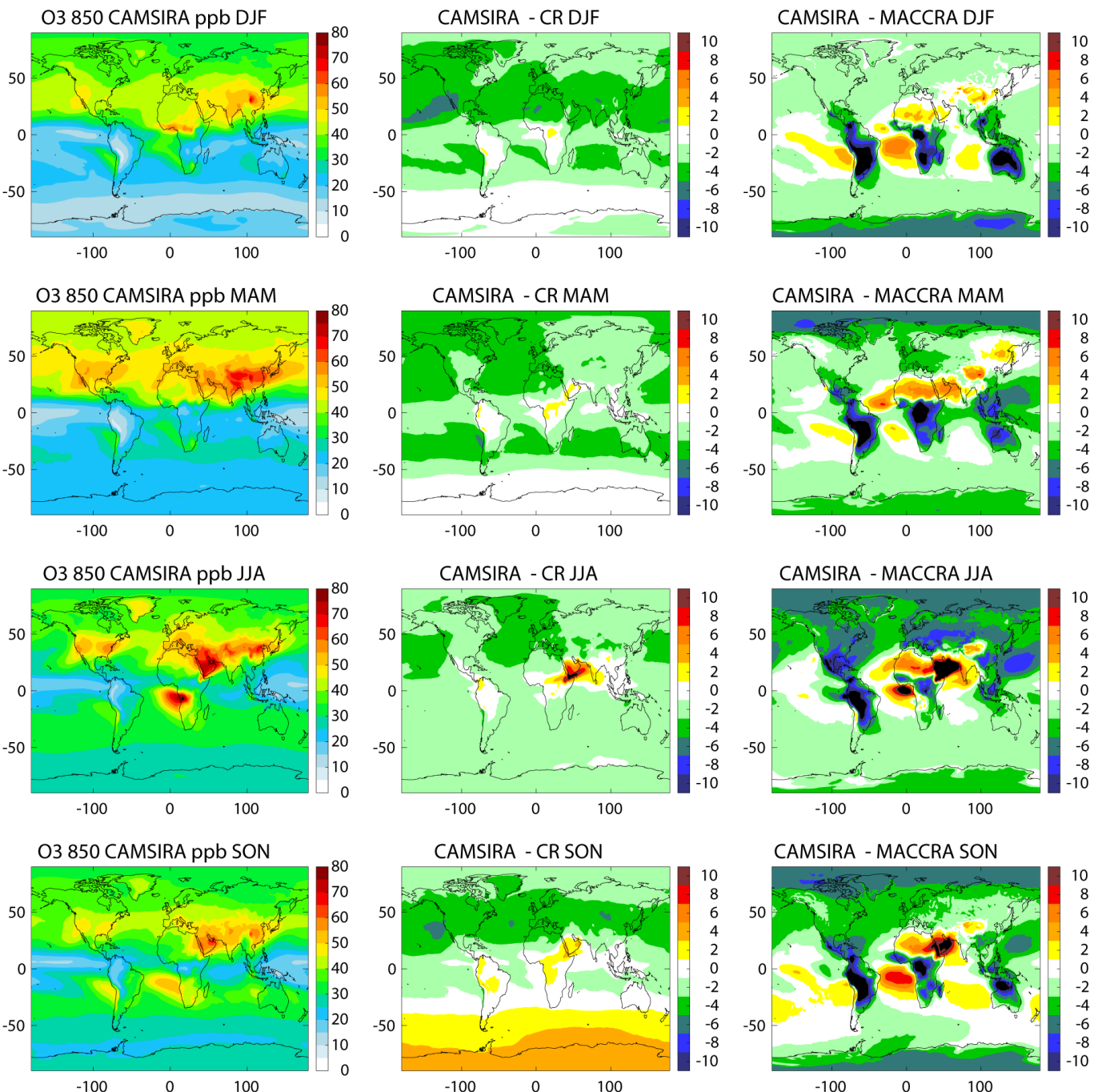

Figure 20. Seasonally averaged ozone at $850 \mathrm{hPa}(\mathrm{ppb})$ from CAMSiRA (left) difference between CAMSIRA and the CR (middle) and CAMSiRA and MACCRA (right, 2003-2012) for the seasons DJF (row 1), MAM (row 2), JJA (row 3) and SON (row 4).

tion by the assimilation in the NH occurred in DJF and the biggest increase occurred in the SH in SON. The largest absolute increases of CAMSiRA of up to $10 \mathrm{ppb}$ occurred over the southern end of the Arabian Peninsula at the time of the seasonal maximum in JJA. This was the only local maximum in CAMSiRA that was increased by the assimilation.

Tropospheric ozone was the only considered species for which the differences between CAMSiRA and MACCRA were larger than the differences between CAMSiRA and the $\mathrm{CR}$. This indicates the importance of the chemistry model parameterization and the limitations of the data assimilation in this respect. In the extratropics of the $\mathrm{NH}$ and $\mathrm{SH}$, CAMSiRA was $2-5$ ppb lower than MACCRA, with an increasing difference towards the poles. The largest difference occurred in the NH summer in JJA. CAMSiRA was up to $10 \mathrm{ppb}$ lower than MACCRA over the continents in the tropics. Conversely, CAMSiRA had higher values than MAC-
CRA over the tropical oceans; this was true for the Sahara as well as at the location of the strong maximum over the Arabian Peninsula, which was not present in MACCRA. The strong land-sea contrast in the differences could be caused by (i) a different efficiency of deposition over the oceans, (ii) the discussed differences in biomass burning emissions or (iii) the differences in the chemical treatment (e.g. the isoprene degradation scheme).

The vertical distribution (see Fig. 14) of the mean ozone partial pressure in the troposphere shows that CAMSiRA was lower than the $\mathrm{CR}$ in the whole troposphere, except for in the tropical upper troposphere, where it was up to $10 \%$ higher, as well as below $500 \mathrm{hPa}$ in the $\mathrm{SH}$ troposphere. Compared to MACCRA, CAMSiRA was up to $20 \%$ higher in the middle and upper troposphere in the tropics and subtropics but increasingly lower towards the surface. 

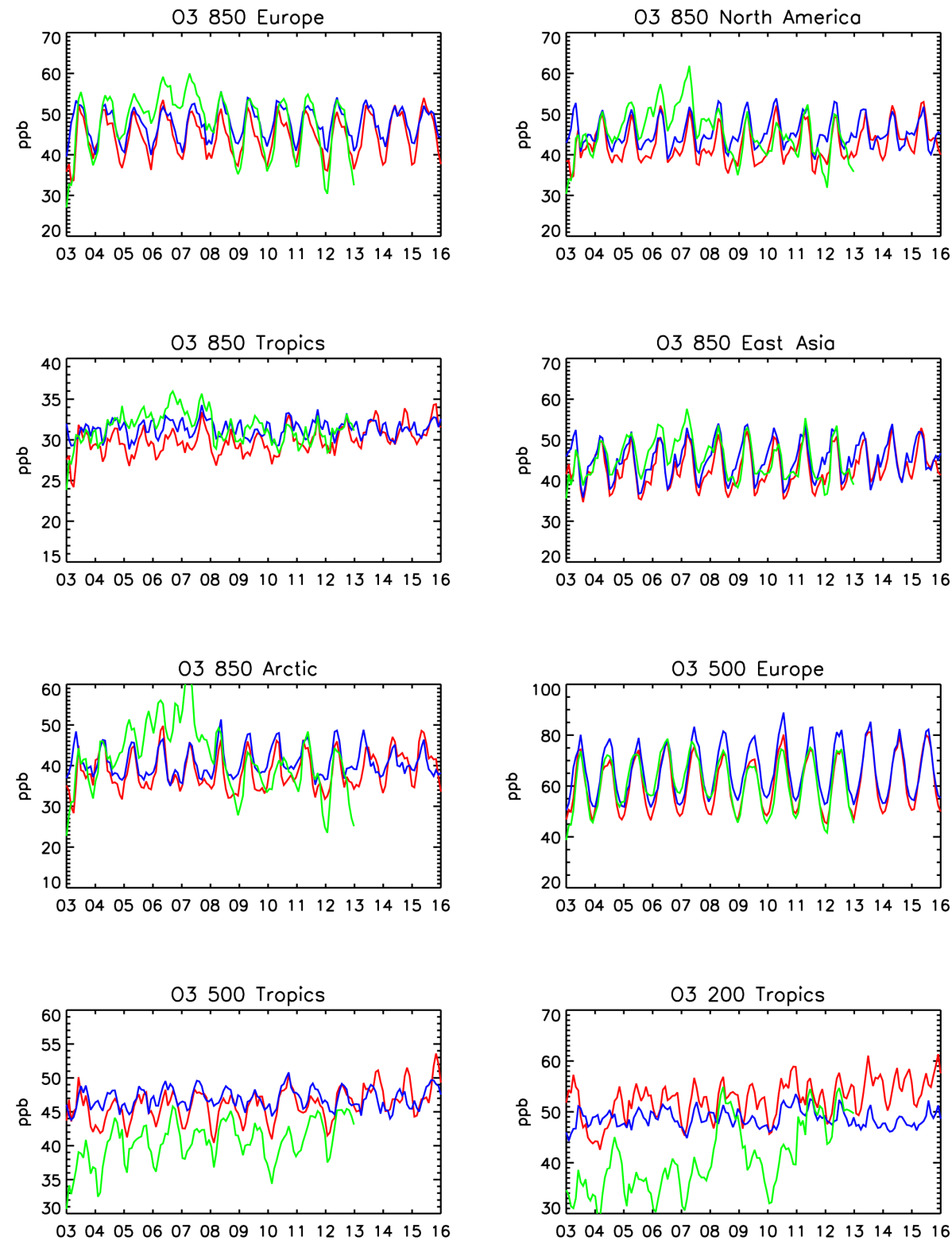

Figure 21. Monthly ozone volume mixing ratios at 850,500 and $200 \mathrm{hPa}$ over different regions (see Table 3) from CAMSiRA (red), the CR (blue) and MACCRA (green) for 2003-2015.

\subsection{Interannual variability}

Estimating and understanding tropospheric ozone trends has been widely studied in the literature, as reviewed in Cooper et al. (2014) and Monks et al. (2015). Factors that influence the interannual variability and trends of tropospheric ozone are changes in anthropogenic and biomass burning emissions, the stratosphere-troposphere exchange and the variability of the meteorological fields. The observed trends vary strongly because these different factors are not uniform in space and time. Trends are often confined to specific seasons or levels. Positive trends are more common than negative trends and are found over Europe and North America during spring (Cooper et al., 2014).

Figure 21 shows time series of average ozone volume mixing rations over selected regions and pressure levels at 850,500 and $200 \mathrm{hPa}$. It is beyond the scope of this paper to investigate the robustness of the trends in CAMSiRA in detail. However, it is worth noting that there were only positive trends in the considered region at 850,500 and $200 \mathrm{hPa}$ in CAMSiRA. The trends varied between 0 and $1.1 \% \mathrm{yr}^{-1}$, with a global mean of $0.5 \% \mathrm{yr}^{-1}$. Many of these trends were significant ( $95 \%$ confidence level). The CR also had mostly positive but much smaller trends, with a global 

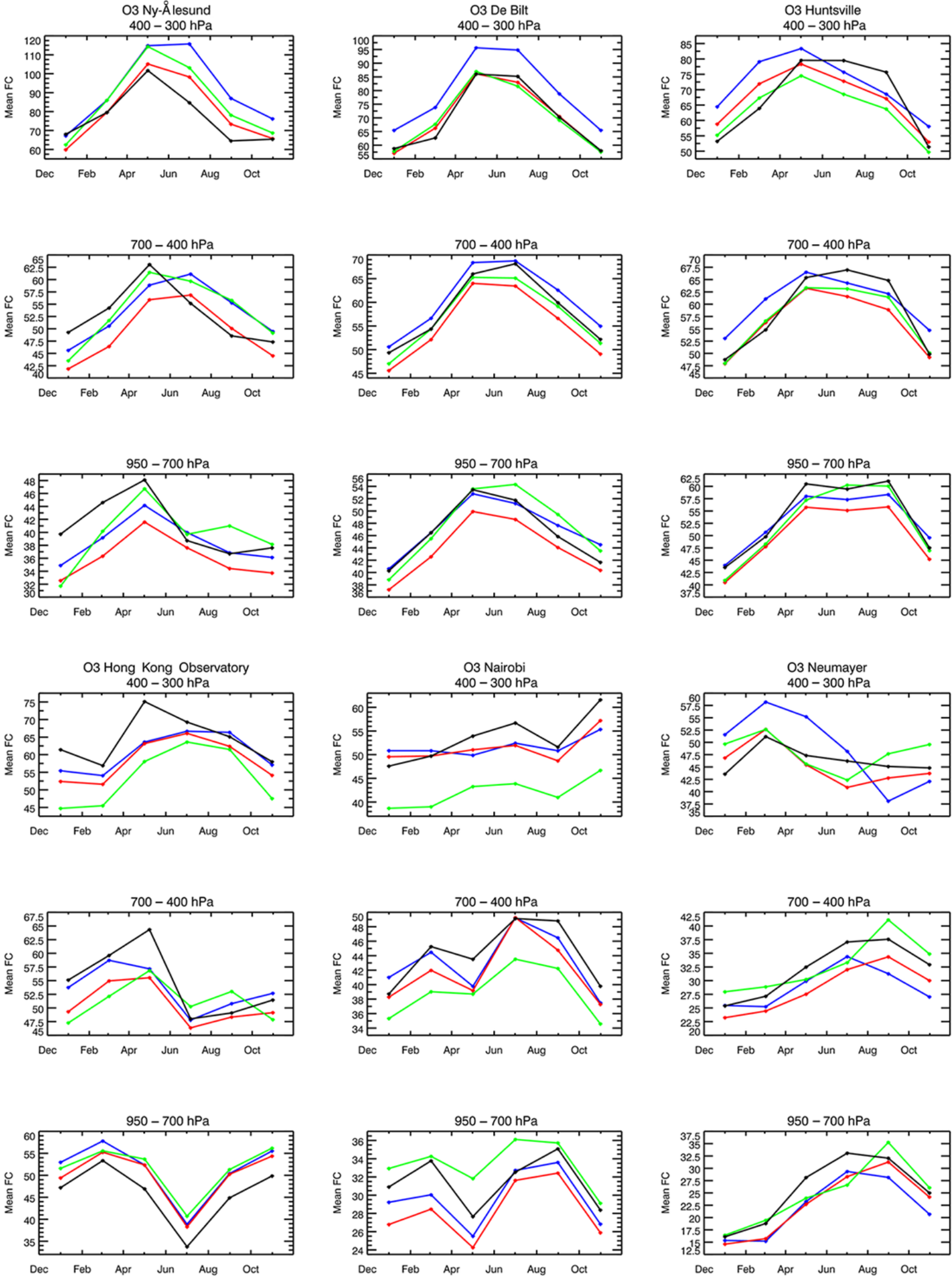

Figure 22. Time series of seasonal mean ozone bias in ppb in the pressure ranges 950-700, 700-400 and 400-300 hPa compared with ozone sondes at Ny-Ålesund, De Bilt, Huntsville, Hong Kong Observatory, Nairobi and Neumayer Station for CAMSiRA (red), the CR (blue) and MACCRA (green). 

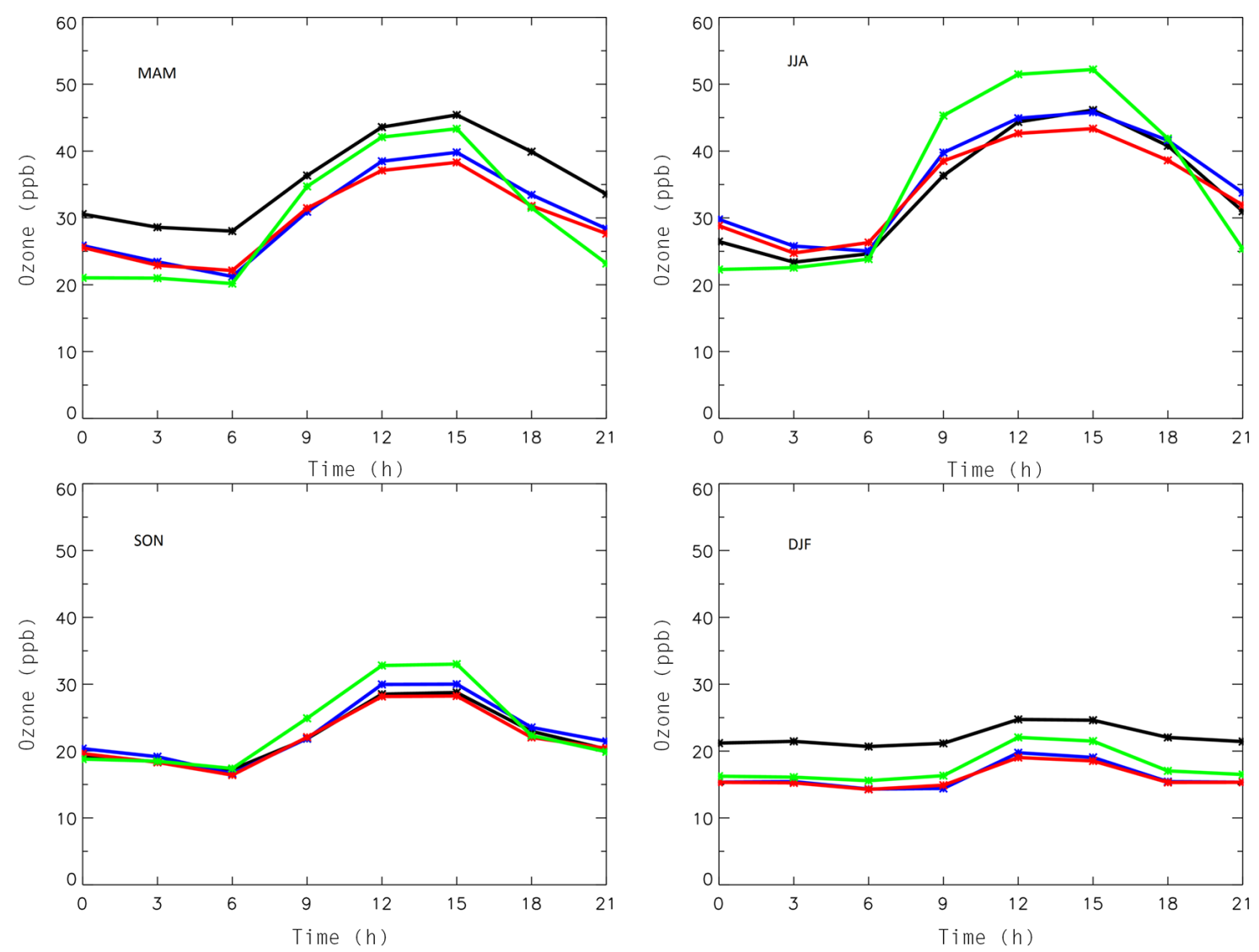

Figure 23. Average diurnal cycle of ozone at EMEP AirBase stations in Europe (black) for the seasons MAM (top left), JJA (top right), SON (bottom left), and DJF (bottom right) for CAMSiRA (red), the CR (blue), and MACCRA (green).

mean of $0.17 \% \mathrm{yr}^{-1}$. The only significant trend in the $\mathrm{CR}$ of $0.35 \% \mathrm{yr}^{-1}$ was found over East Asia and the corresponding trend in CAMSiRA had the same value. Focusing on eastern China, Verstraeten et al. (2015) found a trend of about $1.2 \% \mathrm{yr}^{-1}$ between 2005 and 2010, which is considerably larger than the trend in CAMSiRA and the CR.

The time series in Fig. 21 show that the higher values in the $\mathrm{NH}$ of the $\mathrm{CR}$ with respect to CAMSiRA occurred in the entire troposphere. In the lower and mid-troposphere, CAMSiRA was lower than the CR, especially during the seasonal minimum. In the tropics, the CR and CAMSiRA agreed well at $850 \mathrm{hpa}$, the $\mathrm{CR}$ was slightly higher at $500 \mathrm{hPa}$ and about $5 \mathrm{ppb}$ lower than CAMSiRA at $200 \mathrm{hPa}$. At this level CAMSiRA had a significant trend of $0.95 \% \mathrm{yr}^{-1}$ in the tropics, which was not present in the CR. More detailed studies are needed to confirm the realness of this upper tropospheric trend in CAMSiRA.

A more detailed inspection of the time series shows that from the start of 2013 the CR and CAMSiRA agree to a higher degree than before in the middle and upper part of the troposphere in the NH. The agreement is most likely caused by a reduced correction by the assimilation in the NH troposphere in this period. In early 2013 the assimilated MLS ozone retrieval switched from version V2 to the NRT V3.4 product (see Table 2), which had different levels and observation errors. The discontinuation of MIPAS in spring 2012 does not seem to be the reason for this behaviour.

The year-to-year variability of tropospheric ozone from MACCRA often did not resemble that of CAMSiRA. In the $\mathrm{NH}$ at $850 \mathrm{hPa}$ (most prominently seen in the Arctic), MACCRA had increasing values until 2008, after which they dropped to the values of CAMSiRA. This drift of MACCRA and the associated negative trends are not realistic (as confirmed in Sect. 6.3). They were caused by applying the variational bias correction scheme to MLS data in MACCRA (see Inness at al., 2013 for more details). The agreement between CAMSiRA and MACCRA increases with increasing height in the extratropics, but in the tropics MACCRA showed a much stronger trend at $200 \mathrm{hPa}$ than CAMSiRA.

\subsection{Evaluation with ozone sondes in the troposphere}

Figure 22 shows time series of seasonal biases in pressure ranges representing the lower, middle and upper troposphere from six different ozone sonde sites. The selected stations had at least one observation for each month of the 20032015 period and are examples for Europe (De Bilt), North 
$\mathrm{O}_{3}$ surface EMEP-rural AirBASE

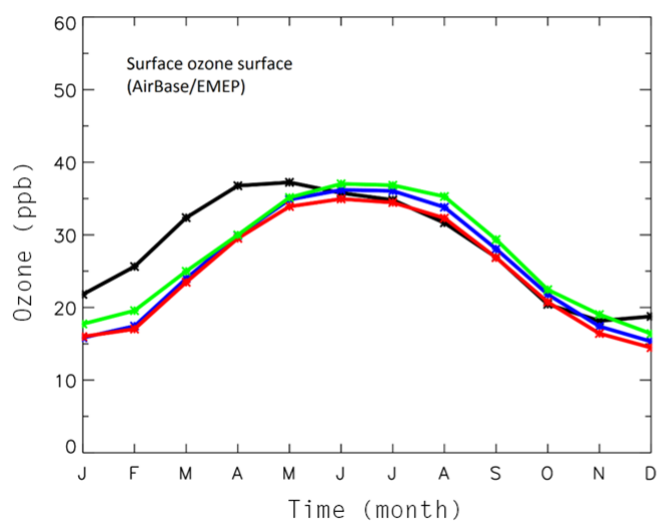

$\mathrm{O}_{3} 950-700 \mathrm{hPa}$ sondes

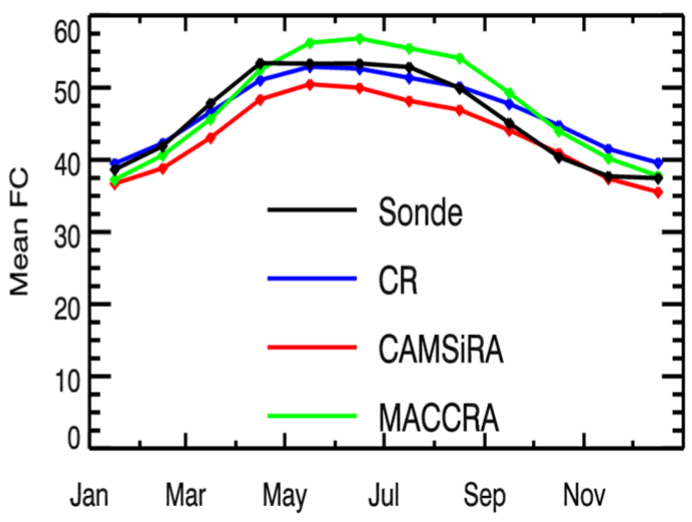

Figure 24. Average seasonal cycle of surface ozone at EMEP AirBase stations (left) and at European ozone sonde sites in the pressure range (950-700 hPa) for CAMSiRA (red), the CR (blue) and MACCRA (green).

America (Huntsville), the tropics (Nairobi), the Arctic (NyÅlesund) and Antarctica (Neumayer Station). To represent South Asia we chose Hong Kong Observatory, which had complete cover from 2003 to 2012. These individual time series depend on the specific characteristics of the individual stations and are therefore less representative than the averages over the gridded data sets shown in Sect. 6.2.

In the lower troposphere $(950-700 \mathrm{hPa})$ over De Bilt, Huntsville and Nairobi, the CR and CAMSiRA had seasonal biases mostly in the range of $-7-7 \mathrm{ppb}$. In the polar regions at Neumayer Station and Ny-Ålesund, both the CR and CAMSiRA underestimated the observations. At all locations CAMSiRA was lower in the lower troposphere than the CR, which meant that CAMSiRA mostly had a larger absolute bias than the CR. At Hong Kong Observatory both CAMSiRA and the CR overestimated the observations, with biases in the range between 0 and $10 \mathrm{ppb}$.

In the middle troposphere the absolute biases of CAMSiRA and the CR were of the same magnitude but of different signs. In the upper troposphere the CR overestimated the observations by about $10 \mathrm{ppb}$, whereas the bias of CAMSiRA remained below $5 \mathrm{ppb}$. The overestimation of the CR is likely caused by the influence of the stratosphere where the CR was too high (see Sect. 5.4). Over Nairobi the biases of the CR and CAMSiRA were very similar in all levels, but CAMSiRA had overall lower biases in the lower troposphere. In the pressure range $400-300 \mathrm{hPa}$ in the tropics, the impact of stratospheric biases on the CR is weaker because of the higher tropopause height in this region.

The biases for all three data sets at Ny-Ålesund, Huntsville and Hong Kong Observatory showed a pronounced seasonality in the middle and upper troposphere. At Huntsville the spring maximum was especially overestimated, i.e. it occurred 2-3 months too early. At Ny-Ålesund the overestimation was caused by too-high values in summer and au- tumn. Over Hong Kong Observatory the pronounced observed spring maximum was not well reproduced.

As already discussed in Sect. 6.2, the characteristics of the bias of CAMSiRA changed at the start of 2013 mainly in the upper parts of the $\mathrm{NH}$ troposphere but also throughout the troposphere over higher latitudes. In this period the CAMSiRA biases resemble the bias of the CR much more, which often means an increase in the average values, which could cause a spurious enhancement of positive trends.

At Neumayer Station CAMSiRA increased in a step-wise manner already at the start of 2012, which changed the bias from an underestimation to a slight overestimation together with an increased seasonality. This behaviour could have been caused by the discontinuation of MIPAS in spring 2012 (see Table 2). Although the MIPAS retrievals were only stratospheric profiles, the assimilation combined with total column retrievals could have triggered a correction in the troposphere (Flemming et al., 2011).

MACCRA had a less stable bias than CAMSiRA. In the lower and mid-troposphere, biases from 2006 to 2008 were much higher than in the rest of the period, when they resembled the biases of CAMSiRA and the CR more. This confirms that the discussed interannual variability of MACCRA seems less realistic than that of the CR and CAMSiRA.

It should be noted that both MACCRA and CAMSiRA suffered from larger-than-typical negative biases in the $\mathrm{NH}$ in the first half of 2003, which can probably be explained by biases in the initial conditions and the short spin-up period of only 1 month.

\subsection{Evaluation with AirBase ozone surface observations}

The AirBase and European Monitoring an Evaluation Programme (EMEP) databases host operational air quality observations from different national European networks. All 
EMEP stations are located in rural areas, while AirBase stations are designed to monitor pollution at different scales. Stations of the rural regime can capture the larger-scale signal, in particular for $\mathrm{O}_{3}$, which is spatially well correlated (Flemming et al., 2005). Therefore, EMEP stations and only rural AirBase stations were used in the evaluation to account for the model resolution of C-IFS.

Figure 23 shows the average diurnal cycle for each season of the observed values and CAMSiRA, the CR and MACCRA. The CR and CAMSiRA were very similar and matched the shape of the observed diurnal cycle well. However, there was a constant bias of about $5 \mathrm{ppb}$ in MAM and DJF. The CR had slightly smaller biases than CAMSiRA in JJA in the afternoon. MACCRA had a larger diurnal range because the daytime values were higher than the ones of CAMSiRA. This meant smaller day-time biases in MAM and DJF and hence a smaller seasonal bias for MACCRA. However, it also led to a considerable (10 ppb) daytime overestimation in JJA and a smaller overestimation in SON, as well as a less-well fit with the shape of the observed diurnal cycle in all seasons.

The winter and spring underestimation of CAMSiRA and the CR has already been reported in Flemming et al. (2015). To investigate the possible causes of this seasonal bias, Fig. 24 shows the average seasonal cycle at the surface at the EMEP AirBase stations and in the lower troposphere (950$750 \mathrm{hPa}$ ) over ozone sonde stations. The differences between CAMSiRA, the CR and MACCRA were more pronounced in the lower troposphere than at the surface. This indicates again that the assimilation has little influence on the surface values. The CR matched the observations in the lower troposphere well in all seasons apart from SON, when it overestimated. MACCRA had biases similar to the CR but overestimated in JJA and especially over southern Europe, as shown in Katragkou et al. (2015). CAMSiRA underestimated throughout the year with the exception of SON. Since the patterns of the seasonal biases were different in the lower troposphere and at the surface, we conclude that the winter and springtime bias at the surface is not predominately caused by tropospheric biases. It is more likely that the simulation of surface processes such as dry deposition and titration by freshly emitted NO are the reasons for this bias at the surface.

\section{Summary and conclusions}

CAMSiRA is a new reanalysis data set of aerosol, $\mathrm{CO}$ and ozone for the period 2003-2015. It was produced by assimilating satellite retrievals of AOD and TC CO as well as TC and stratospheric ozone profile retrievals from various sensors in C-IFS using the ECMWF 4D-VAR approach. A similar set of observations was assimilated in MACCRA, a previous reanalysis data set for the period 2003-2012. A control run with C-IFS (CR) without the assimilation of AC observations was carried out to infer the impact of the assimilated observations.

\subsection{CAMSiRA compared to MACCRA}

Compared to its predecessor MACCRA, CAMSiRA had smaller biases of surface and lower-tropospheric $\mathrm{CO}$, as shown by the comparison with MOZAIC-IAGOS CO profiles and NOAA-GMD CO flask observations. However, MACCRA had lower CO biases in the NH middle and upper troposphere with respect to the MOZAIC-IAGOS CO profiles. The biases of TC ozone compared with the WOUDC Dobson sun photometers were reduced from 5-10DU in MACCRA to $0-5$ DU in CAMSiRA. The biases of CAMSiRA compared with AERONET AOD observations were lower in most parts of the globe, with the exception of South East Asia. A larger improvement was the elimination of the positive bias of upper stratospheric ozone in MACCRA, as shown by the comparison with the GOZCARDS ozone product. CAMSiRA also had a better agreement with the shape of the mean observed diurnal cycle of AirBase ground-level ozone observations in Europe in all seasons, but winter and spring seasonal values were still underestimated by $5 \mathrm{ppb}$. We attribute all the aforementioned differences between CAMSiRA and MACCRA, which were mainly improvements, to the change in the assimilating model, which was the coupled system IFS-MOZART for MACCRA and C-IFS with updated aerosol parameterisations for CAMSiRA.

Progress achieved by changes in the assimilated observations was a noteworthy improvement of the temporal consistency of the tropospheric $\mathrm{CO}$ and ozone fields in CAMSiRA. The assimilation of IASI CO in MACCRA from 2008 onwards had led to a decrease in the TC CO values because of the biases against the MOPITT data set, which was assimilated during the whole period. Consequently, the MACCRA $\mathrm{CO}$ fields in the middle and high latitudes of both hemispheres showed strong negative trends which were not in agreement with linear trends estimated from $\mathrm{CO}$ flask surface observations. Conversely, the linear trends of CAMSiRA agreed well with the observed trends, which were close to zero in the $\mathrm{SH}$ and reached values of about $2 \mathrm{ppb} \mathrm{yr}^{-1}$ in the NH middle and high latitudes. The mid- and uppertropospheric ozone fields of MACCRA suffered from an increase in the period 2004-2008, caused by applying disproportionate application of the inter-instrument bias correction to the MLS column retrievals, which was corrected for CAMSiRA (Inness et al., 2015).

A discontinuity in the upper- and mid-tropospheric ozone field was noted for CAMSiRA after January of 2013 and was due to a change in version of the assimilated MLS ozone retrievals. Although this change in CAMSiRA did not mean an increase in the bias, it has to be considered when trends of tropospheric ozone fields are to be calculated from the CAMSiRA data set.

The AOD in CAMSiRA was about 0.01 lower than MACCRA in most parts of the globe, mainly because of a $50 \%$ lower burden of sea salt in CAMSiRA. CAMSiRA had higher AOD values over the desert-dust-emitting regions in 
northern Africa, and the global desert dust burden was higher in CAMSiRA. CAMSiRA had $25 \%$ higher AOD contribution from sulfate than MACCRA, which is currently under scrutiny.

\subsection{CAMSiRA compared to the CR}

The comparison with the $\mathrm{CR}$ showed that the assimilation led to a clear improvement for $\mathrm{CO}, \mathrm{AOD}$ and $\mathrm{TC}$ ozone as well as stratospheric and upper-tropospheric ozone.

The assimilation of MOPITT CO increased the values in the $\mathrm{NH}$ mid-latitudes more in the beginning of the period, which could indicate a stronger underestimation of the anthropogenic emissions in this period as well as an overestimation of the trend in the emissions. The tropical and $\mathrm{SH}$ values were reduced by the assimilation, which may indicate an overestimation of the biomass burning emissions in this region. However, the rather zonally homogeneous $\mathrm{CO}$ differences between the CR and CAMSiRA suggest that not only biases in the fire emissions but also in the $\mathrm{CO}$ lifetime, chemical production and $\mathrm{CO}$ transport need to be investigated further.

The Cariolle scheme for stratospheric ozone, which was used in C-IFS, suffered from a large overestimation of $\mathrm{NH}$ mid-and high latitude stratospheric ozone (40-60 DU) and an underestimation in the tropics ( $-20 \mathrm{DU})$. These biases were corrected for by the assimilation and the resulting biases of CAMSiRA were of $5 \mathrm{DU}$ and lower. In the SH high latitudes, the Cariolle scheme also overestimated the mean TCs, especially in JJA, by up to $30 \mathrm{DU}$, but the depth and the yearto-year variability of the ozone hole was well reproduced by the CR. Nevertheless, CAMSiRA had more realistic TCs and profiles than the CR during the annual ozone hole events.

The assimilation had little impact on the ozone values at the surface and in the lower troposphere, where the biases of CAMSiRA were sometimes slightly more negative than those of the CR. The small influence could be explained by the fact, that dry deposition velocities and important ozone precursors such as $\mathrm{NO}_{x}$ were not constrained during the assimilation process. Also contributing was the fact that no direct tropospheric ozone observations were assimilated, nor were the vertical correlations in the model background errors strong enough to cause a correction of the surface levels based on the levels above. The assimilation was more beneficial in the upper troposphere, where the stratospheric influence is more important.

CAMSiRA had AOD values about 0.05 higher than the $\mathrm{CR}$, apart from the desert dust emission regions, where the assimilation strongly reduced the modelled values. CAMSiRA tended to slightly overestimate the AERONET AOD observations and the CR tended to underestimate them, but the overall biases of CAMSiRA were smaller.

Despite moderate differences in AOD, the CR and CAMSiRA had considerable differences in the aerosol speciation. The global annual sea salt burden by C-IFS in the CR of
$15 \mathrm{Tg}$ was considerably higher than the result of other modelling studies (Textor et al., 2006; Spada et al., 2012). Less efficient loss processes may have played a large role in this overestimation. The assimilation strongly reduced the sea salt burden in CAMSiRA to about half of the value in the $\mathrm{CR}$. The global desert dust burden was also reduced by $25 \%$ by the assimilation, leading to lower total AOD values over the desert dust emission regions of the Sahara, Australia and middle Asia. Despite the fact that CAMSiRA had a $30 \%$ smaller global aerosol burden than the CR, its average global AOD was about $10 \%$ higher than that of the CR. This was caused by a strong increase in sulfate in CAMSiRA. The optical properties and assumed size distribution of sulfate make extinction more efficient for the same amount of mass. Sulphate became the dominant contribution to AOD in the regions away from the main aerosol emissions. The strong contribution of sulfate may have partly compensated for the inadequate representation of other secondary aerosols in CIFS. However, its magnitude and spread over the whole globe seems excessive. It might be caused by the lack of strong loss processes in the free troposphere as well as biases in the assimilated observations over the open oceans. As the CR underestimates the assimilated AOD, the aerosol mass is increased during the assimilation, initially by the same relative amount for all components. However, a longer lifetime of sulfate causes a longer lasting change compared to the other aerosol species, which made sulfate the dominating aerosol. This distortion of the speciation can not be corrected for by the assimilated MODIS AOD retrievals, which do not contain information about the speciation.

\subsection{Recommendations for future $\mathrm{AC}$ reanalysis}

CAMSiRA is a considerable improvement over MACCRA, especially with respect to the temporal consistency. To further improve on this important aspect, one should make sure that consistent input emission data sets and assimilated observations are used. Changes in the assimilated observations, such as the version change of the MLS data after 2012, should be avoided. The use of MEGAN-simulated biogenic emissions for the whole period is advisable even if no related jumps were detected in this study. To ensure consistency between the aerosols and chemistry components, the same $\mathrm{SO}_{2}$ emissions should be used.

Since improvements to lower-tropospheric ozone by assimilating current satellite observations are difficult to achieve, emphasis needs to be put on the improved simulation of chemistry and dry deposition. The assimilation of tropospheric ozone column retrievals as well as of tropospheric $\mathrm{NO}_{2}$ may further help to improve the ground-level ozone in the reanalysis.

One prospect is to enable the correction of emissions based on observations of atmospheric composition with the C-IFS data assimilation system. This could also improve the analysis of tropospheric ozone since ozone precursor emissions 
would be corrected. An intermediate step in this direction is to better account for the emission uncertainty in the model background error statistics.

The high sulfate burden introduced by the assimilation can be avoided by (i) the introduction of more intensive loss processes in the free troposphere, (ii) an increase in the organic matter to better represent non-accounted SOA components and (iii) changes to the vertical structure of the background errors to avoid the accumulation of aerosol mass away from the surface. In general, any modelling improvements for a better speciation will reflect in a more realistic aerosol analysis and a better exploitation of the available observations. If possible the latest reprocessed MODIS AOD data set should be used (collection 6).

In CAMSiRA and MACCRA the aerosol and chemistry schemes were independent. A better coupling between the two and the meteorological simulation is desirable. For example, the use of aerosol to modulate photolysis rates and heterogeneous uptake of aerosol as well as simulating the impact on aerosols and ozone within the radiation transfer calculation of IFS will be important next steps.

\section{Data availability}

The CAMSiRA, CR and MACCRA data are freely available. Please contact copernicus-support@ecmwf.int.

\section{The Supplement related to this article is available online at doi:10.5194/acp-17-1945-2017-supplement.}

Competing interests. The authors declare that they have no conflict of interest.

Acknowledgements. CAMS is funded by the European Union's Copernicus Programme. The GOZCARDS data were obtained from the NASA Goddard Earth Science Data and Information Services Center. We are grateful to the World Ozone and Ultraviolet Radiation Data Centre (WOUDC) for providing ozone sonde and Dobson photometer observations. We thank the Global Atmospheric Watch programme for the provision of $\mathrm{CO}$ and ozone surface observations. We thank the European Environmental Agency for providing access to European ozone observations in the AirBase database. We also thank the MOZAIC (Measurements of OZone, water vapour, carbon monoxide and nitrogen oxides by in-service AIrbus aircraft) and IAGOS (In-Service Aircraft for a Global Observing System) programmes for providing CO profile observations.

Edited by: C. H. Song

Reviewed by: two anonymous referees

\section{References}

Auligne, T., McNally, A. P., and Dee, D. P.: Adaptive bias correction for satellite data in a numerical weather prediction system, Q. J. Roy. Meteor. Soc., 133, 631-642, 2007.

Basher, R. E.: Review of the Dobson spectrophotometer and its accuracy, Global Ozone Res. Monit. Proj., Rep. 13, World Meteor. Organ., Geneva, Switzerland, December, available at: http://www.esrl.noaa.gov/gmd/ozwv/dobson/papers/report13/ report13.html (last access: 3 February 2017), 1982.

Bechtold, P., Orr, A. Morcrette, J.-J., Engelen, R., Flemming, J., and Janiskova, M.: Improvements in the stratosphere and mesosphere of the IFS, ECMWF Newsletter No. 120, Summer, 2009.

Beekmann M., Ancellet G., Megie G., Smit H. G. J., and Kley D.: Intercomparison campaign for vertical ozone profiles including electrochemical sondes of ECC and Brewer-Mast type and aground based UV-differential absorption radar, J. Atmos. Chem., 10, 259-288, 1994.

Bellouin, N., Quaas, J., Morcrette, J.-J., and Boucher, O.: Estimates of aerosol radiative forcing from the MACC re-analysis, Atmos. Chem. Phys., 13, 2045-2062, doi:10.5194/acp-13-20452013, 2013.

Benedetti, A., Morcrette, J.-J., Boucher, O., Dethof, A., Engelen, R. J., Fisher, M., Flentje, H., Huneeus, N., Jones, L.,Kaiser, J. W., Kinne, S., Mangold, A., Razinger, M., Simmons, A. J., Suttie, M., and the GEMS-AER team: Aerosol analysis and forecast in the European Centre for Medium-Range Weather Forecasts Integrated Forecast System: 2. Data assimilation, J. Geophys. Res., 114, D13205, doi:10.1029/2008JD011115, 2009.

Benedetti, A. Jones, L., Kaiser, J. W., Morcrette, J.-J., and Rémy, S.: Global climate, Aerosols, in: State of the Climate in 2013, B. Am. Meteorol. Soc., 95, 36-37, 2014.

Bhartia, P. K. and Wellemeyer, C.: TOMS-V8 total $\mathrm{O}_{3}$ algorithm, in: OMI Ozone Product ATBD, NASA Goddard Space Flight Center, Greenbelt, MD, USA, Volume II, 15-31, 2002.

Bhartia, P. K., McPeters, R. D., Mateer, C. L., Flynn, L. E., and Wellemeyer, C., Algorithm for the estimation of vertical ozone profiles from the backscattered ultraviolet technique, J. Geophys. Res., 101, 18793-18806, 1996.

Bocquet, M., Elbern, H., Eskes, H., Hirtl, M., Žabkar, R., Carmichael, G. R., Flemming, J., Inness, A., Pagowski, M., Pérez Camaño, J. L., Saide, P. E., San Jose, R., Sofiev, M., Vira, J., Baklanov, A., Carnevale, C., Grell, G., and Seigneur, C.: Data assimilation in atmospheric chemistry models: current status and future prospects for coupled chemistry meteorology models, Atmos. Chem. Phys., 15, 5325-5358, doi:10.5194/acp-15-53252015, 2015.

Boucher, O.: Atmospheric Aerosols, Properties and Climate Impacts, Springer Netherlands, doi:10.1007/978-94-017-9649-1, 311 pp., 2015.

Cariolle, D. and Dèquè, M.:. Southern hemisphere medium-scale waves and total ozone disturbances in a spectral general circulation model, J. Geophys. Res., 91, 10825-10846, 1986.

Cariolle, D. and Teyssèdre, H.: A revised linear ozone photochemistry parameterization for use in transport and general circulation models: multi-annual simulations, Atmos. Chem. Phys., 7, $2183-$ 2196, doi:10.5194/acp-7-2183-2007, 2007.

Cesnulyte, V., Lindfors, A. V., Pitkänen, M. R. A., Lehtinen, K. E. J., Morcrette, J.-J., and Arola, A.: Comparing ECMWF AOD with AERONET observations at visible and UV wave- 
lengths, Atmos. Chem. Phys., 14, 593-608, doi:10.5194/acp-14593-2014, 2014.

Coldewey-Egbers, M., Loyola R., D. G., Braesicke, P., Dameris, M., van Roozendael, M., Lerot, C., and Zimmer, W.: A new health check of the ozone layer at global and regional scales, Geophys. Res. Lett., 41, 4363-4372, doi:10.1002/2014GL060212, 2014.

Cooper, O. R., Parrish, D. D., Ziemke, J., Balashov, N. V., Cupeiro, M., Galbally, I. E., Gilge, S., Horowitz, L., Jensen, N. R., Lamarque, J.-F., Naik, V., Oltmans, S. J., Schwab, J., Shindell, D. T., Thompson, A. M., Thouret, V., Wang, Y., and Zbinden, R. M.: Global distribution and trends of tropospheric ozone: An observation-based review, Elementa, 2, 1-28, doi:10.12952/journal.elementa.000029, 2014.

Courtier, P., Thépaut, J.-N., and Hollingsworth, A.: A strategy for operational implementation of 4D-Var, using an incremental approach, Q. J. Roy. Meteor. Soc., 120, 1367-1388, 1994.

Cuevas, E., Camino, C., Benedetti, A., Basart, S., Terradellas, E., Baldasano, J. M., Morcrette, J. J., Marticorena, B., Goloub, P., Mortier, A., Berjón, A., Hernández, Y., Gil-Ojeda, M., and Schulz, M.: The MACC-II 2007-2008 reanalysis: atmospheric dust evaluation and characterization over northern Africa and the Middle East, Atmos. Chem. Phys., 15, 3991-4024, doi:10.5194/acp-15-3991-2015, 2015.

Dee, D. P.: Variational bias correction of radiance data in the ECMWF system, in: Proceedings of the ECMWF workshop on assimilation of high spectral resolution sounders in NWP, Reading, UK, 28 June-1 July 2004, 97-112, 2004.

Dee, D. P. and Uppala, S.: Variational bias correction of satellite radiance data in the ERA-Interim reanalysis, Q. J. Roy. Meteor. Soc., 135, 1830-1841, 2009.

Dee, D. P., Uppala, S. M., Simmons, A. J., Berrisford, P., Poli, P., Kobayashi, S., Andrae, U., Balmaseda, M. A., Balsamo, G., Bauer, P., Bechtold, P., Beljaars, A. C. M., van de Berg, L., Bidlot, J., Bormann, N., Delsol, C., Dragani, R., Fuentes, M., Geer, A. J., Haimberger, L., Healy, S. B., Hersbach, H., Hólm, E. V., Isaksen, L., Kållberg, P., Köhler, M., Matricardi, M., McNally, A. P., Monge-Sanz, B. M., Morcrette, J.-J., Park, B.-K., Peubey, C., de Rosnay, P., Tavolato, C., Thépaut, J.-N., and Vitart, F.: The ERA-Interim reanalysis: Configuration and performance of the data assimilation system, Q. J. Roy. Meteor. Soc., 137, 553-597, doi:10.1002/qj.828, 2011.

Deeter, M. N.: MOPITT Version 5 Product User's Guide, Technical Report, NCAR, Boulder, USA, http://www.acom.ucar. edu/mopitt/v5_users_guide_beta.pdf (last access 24 July 2016), 2011.

Deeter, M. N., Martínez-Alonso, S., Edwards, D. P., Emmons, L. K., Gille, J. C., Worden, H. M., Pittman, J. V., Daube, B. C., and Wofsy, S. C.: Validation of MOPITT Version 5 thermalinfrared, near-infrared, and multispectral carbon monoxide profile retrievals for 2000-2011, J. Geophys. Res.-Atmos., 118, 6710-6725, doi:10.1002/jgrd.50272, 2013.

de Laat, A. T. J., Aben, I., Deeter, M., Nédélec, P., Eskes, H., Attié, J.-L., Ricaud, P., Abida, R., El Amraoui, L., and Landgraf, J.: Validation of nine years of MOPITT V5 NIR using MOZAIC/IAGOS measurements: biases and long-term stability, Atmos. Meas. Tech., 7, 3783-3799, doi:10.5194/amt-7-37832014, 2014.

Dentener, F., Kinne, S., Bond, T., Boucher, O., Cofala, J., Generoso, S., Ginoux, P., Gong, S., Hoelzemann, J. J., Ito, A., Marelli, L.,
Penner, J. E., Putaud, J.-P., Textor, C., Schulz, M., van der Werf, G. R., and Wilson, J.: Emissions of primary aerosol and precursor gases in the years 2000 and 1750 prescribed data-sets for AeroCom, Atmos. Chem. Phys., 6, 4321-4344, doi:10.5194/acp-64321-2006, 2006.

Diamantakis, M. and Flemming, J.: Global mass fixer algorithms for conservative tracer transport in the ECMWF model, Geosci. Model Dev., 7, 965-979, doi:10.5194/gmd-7-965-2014, 2014.

Elguindi, N., Clark, H., Ordóñez, C., Thouret, V., Flemming, J., Stein, O., Huijnen, V., Moinat, P., Inness, A., Peuch, V.-H., Stohl, A., Turquety, S., Athier, G., Cammas, J.-P., and Schultz, M.: Current status of the ability of the GEMS/MACC models to reproduce the tropospheric $\mathrm{CO}$ vertical distribution as measured by MOZAIC, Geosci. Model Dev., 3, 501-518, doi:10.5194/gmd-3501-2010, 2010.

Emmons, L. K., Arnold, S. R., Monks, S. A., Huijnen, V., Tilmes, S., Law, K. S., Thomas, J. L., Raut, J.-C., Bouarar, I., Turquety, S., Long, Y., Duncan, B., Steenrod, S., Strode, S., Flemming, J., Mao, J., Langner, J., Thompson, A. M., Tarasick, D., Apel, E. C., Blake, D. R., Cohen, R. C., Dibb, J., Diskin, G. S., Fried, A., Hall, S. R., Huey, L. G., Weinheimer, A. J., Wisthaler, A., Mikoviny, T., Nowak, J., Peischl, J., Roberts, J. M., Ryerson, T., Warneke, C., and Helmig, D.: The POLARCAT Model Intercomparison Project (POLMIP): overview and evaluation with observations, Atmos. Chem. Phys., 15, 6721-6744, doi:10.5194/acp15-6721-2015, 2015.

Eskes, H., Huijnen, V., Arola, A., Benedictow, A., Blechschmidt, A.-M., Botek, E., Boucher, O., Bouarar, I., Chabrillat, S., Cuevas, E., Engelen, R., Flentje, H., Gaudel, A., Griesfeller, J., Jones, L., Kapsomenakis, J., Katragkou, E., Kinne, S., Langerock, B., Razinger, M., Richter, A., Schultz, M., Schulz, M., Sudarchikova, N., Thouret, V., Vrekoussis, M., Wagner, A., and Zerefos, C.: Validation of reactive gases and aerosols in the MACC global analysis and forecast system, Geosci. Model Dev., 8, 3523-3543, doi:10.5194/gmd-8-3523-2015, 2015.

Field, R. D., van der Werf, G. R., and Shen, S. S. P.: Human amplification of drought-induced biomass burning in Indonesia since 1960, Nat. Geosci., 2, 185-188, doi:10.1038/ngeo443, 2009.

Flemming, J. and Inness, A.: Global climate, Carbon Monxide, in: State of the Climate in 2013, B. Am. Meteorol. Soc., 95, S43, 2014.

Flemming, J., Stern, R., and Yamartino, R. J.: A new air quality regime classification scheme for $\mathrm{O}_{3}, \mathrm{NO}_{2}, \mathrm{SO}_{2}$ and $\mathrm{PM}_{10}$ observations sites, Atmos. Environ., 39, 6121-6129, 2005.

Flemming, J., Inness, A., Flentje, H., Huijnen, V., Moinat, P., Schultz, M. G., and Stein, O.: Coupling global chemistry transport models to ECMWF's integrated forecast system, Geosci. Model Dev., 2, 253-265, doi:10.5194/gmd-2-253-2009, 2009.

Flemming, J., Inness, A., Jones, L., Eskes, H. J., Huijnen, V., Schultz, M. G., Stein, O., Cariolle, D., Kinnison, D., and Brasseur, G.: Forecasts and assimilation experiments of the Antarctic ozone hole 2008, Atmos. Chem. Phys., 11, 1961-1977, doi:10.5194/acp-11-1961-2011, 2011.

Flemming, J., Huijnen, V., Arteta, J., Bechtold, P., Beljaars, A., Blechschmidt, A.-M., Diamantakis, M., Engelen, R. J., Gaudel, A., Inness, A., Jones, L., Josse, B., Katragkou, E., Marecal, V., Peuch, V.-H., Richter, A., Schultz, M. G., Stein, O., and Tsikerdekis, A.: Tropospheric chemistry in the Integrated Fore- 
casting System of ECMWF, Geosci. Model Dev., 8, 975-1003, doi:10.5194/gmd-8-975-2015, 2015.

Froidevaux, L., Anderson, J., Wang, H.-J., Fuller, R. A., Schwartz, M. J., Santee, M. L., Livesey, N. J., Pumphrey, H. C., Bernath, P. F., Russell III, J. M., and McCormick, M. P.: Global OZone Chemistry And Related trace gas Data records for the Stratosphere (GOZCARDS): methodology and sample results with a focus on $\mathrm{HCl}, \mathrm{H}_{2} \mathrm{O}$, and $\mathrm{O}_{3}$, Atmos. Chem. Phys., 15, 1047110507, doi:10.5194/acp-15-10471-2015, 2015.

Froidevaux, L., Jiang, Y. B., Lambert, A., Livesey, N. J., Read, W. G., Waters, J. W., Browell, E. V., Hair, J. W., Avery, M. A., McGee, T. J., Twigg, L.W., Sumnicht, G. K., Jucks, K.W., Margitan, J. J., Sen, B., Stachnik, R. A., Toon, G. C., Bernath, P. F., Boone, C. D., Walker, K. A., Filipiak, M. J., Harwood, R. S., Fuller, R. A., Manney, G. L., Schwartz, M. J., Daffer, W. H., Drouin, B. J., Cofield, R. E., Cuddy, D. T., Jarnot, R. F., Knosp, B.W., Perun, V. S., Snyder, W. V., Stek, P. C., Thurstans, R. P., and Wagner, P. A.: Validation of Aura Microwave LimbSounder stratospheric ozone measurements, J. Geophys. Res., 113, D15S20, doi:10.1029/2007JD008771, 2008.

Gaubert, B., Arellano Jr. A. F., Barré, J., Worden, H. M., Emmons, L. K., Tilmes, S., Buchholz, R. R., Vitt, F., Raeder, K., Collins, N., Anderson, J. L., Wiedinmyer, C., Martinez Alonso, S., Edwards, D. P., Andreae, M. O., Hannigan, J. W., Petri, C., Strong, K., and Jones, N.: Toward a chemical reanalysis in a coupled chemistry-climate model: An evaluation of MOPITT CO assimilation and its impact on tropospheric composition, J. Geophys. Res.-Atmos., 121, 7310-7343, doi:10.1002/2016JD024863, 2016.

Gaudel, A., Clark, H., Thouret, V., Jones, L., Inness, A., Flemming, J., Stein, O., Huijnen, V., Eskes, H., Nédélec, P., and Boulangerand, D.: On the use of MOZAIC-IAGOS data to assess the ability of the MACC reanalysis to reproduce the distribution of $\mathrm{O}_{3}$ and $\mathrm{CO}$ in the UTLS over Europe, Tellus B, 67, 27955, doi:10.3402/tellusb.v67.27955, 2015.

George, M., Clerbaux, C., Bouarar, I., Coheur, P.-F., Deeter, M. N., Edwards, D. P., Francis, G., Gille, J. C., Hadji-Lazaro, J., Hurtmans, D., Inness, A., Mao, D., and Worden, H. M.: An examination of the long-term $\mathrm{CO}$ records from MOPITT and IASI: comparison of retrieval methodology, Atmos. Meas. Tech., 8, 43134328, doi:10.5194/amt-8-4313-2015, 2015.

Giordano, L., Brunner, D., Flemming, J., Hogrefe, C., Im, U., Bianconi, R., Badia, A., Balzarini, A., Baró, R., Chemel, C., Curci, G., Forkel, R., Jiménez-Guerrero, P., Hirtl, M., Hodzic, A., Honzak, L., Jorba, O., Knote, C., Kuenen, J. J. P., Makar, P. A., MandersGroot, A., Neal, L., Pérez, J. L., Pirovano, G., Pouliot, G., San José, R., Savage, N., Schröder,W., Sokhi, R. S., Syrakov, D., Torian,A., Tuccella, P., Werhahn, J., Wolke, R., Yahya, K., Žabkar, R., Zhang, Y., and Galmarini, S.: Assessment of the MACC reanalysis and its influence as chemical boundary conditions for regional air quality modelling in AQMEII-2, Atmos. Environ., $115,371-388,2015$

Granier, C., Lamarque, J. F., Mieville, A., Muller, J. F., Olivier, J., Orlando, J., Peters, J., Petron, G., Tyndall, G., and Wallens, S.: POET, a database of surface emissions of ozone precursors, available at: http://www.aero.jussieu.fr/projet/ACCENT/POET. php (last access: 3 February 2017), 2005.

Granier, C., Bessagnet, B., Bond, T., D’Angiola, A., v. d. Gon, H. D., Frost, G. J., Heil, A., Kaiser, J. W., Kinne, S., Klimont, Z.,
Kloster, S., Lamarque, J.-F., Liousse, C., Masui, T., Meleux, F., Mieville, A., Ohara, T., Raut, J.-C., Riahi, K., Schultz, M. G., Smith, S. J., Thomson, A., v. Aardenne, J., v. d. Werf, G. R., and v. Vuuren, D. P.: Evolution of anthropogenic and biomass burning emissions of air pollutants at global and regional scales during the 1980-2010 period, Climatic Change, 109, 163-190, doi:10.1007/s10584-011-0154-1, 2011.

Grythe, H., Ström, J., Krejci, R., Quinn, P., and Stohl, A.: A review of sea-spray aerosol source functions using a large global set of sea salt aerosol concentration measurements, Atmos. Chem. Phys., 14, 1277-1297, doi:10.5194/acp-14-1277-2014, 2014.

Guenther, A. B., Karl, T., Harley, P., Wiedinmyer, C., Palmer, P. I., and Geron, C.: Estimates of global terrestrial isoprene emissions using MEGAN (Model of Emissions of Gases and Aerosols from Nature), Atmos. Chem. Phys., 6, 3181-3210, doi:10.5194/acp-63181-2006, 2006.

Hao, N., Koukouli, M. E., Inness, A., Valks, P., Loyola, D. G., Zimmer, W., Balis, D. S., Zyrichidou, I., Van Roozendael, M., Lerot, C., and Spurr, R. J. D.: GOME-2 total ozone columns from MetOp-A/MetOp-B and assimilation in the MACC system, Atmos. Meas. Tech., 7, 2937-2951, doi:10.5194/amt-7-2937-2014, 2014.

Holben, B. N., Eck, T. F., Slutsker, I., Tanré, D., Buis, J. P., Setzer, A., Vermote, E., Reagan, J. A., Kaufman, Y., Nakajima, T., Lavenu, F., Jankowiak, I., and Smirnov, A.: AERONET - A federated instrument network and data archive for aerosol characterization, Remote Sens. Environ., 66, 1-16, 1998.

Hollingsworth, A., Engelen, R. J., Textor, C., Benedetti, A., Boucher, O., Chevallier, F., Dethof, A., Elbern, H., Eskes, H., Flemming, J., Granier, C., Kaiser, J. W., Morcrette, J.-J., Rayner, P., Peuch, V. H., Rouil, L., and Schultz, M. G.: Simmons, A. J. and The GEMS Consortium: Toward a Monitoring and Forecasting System For Atmospheric Composition: The GEMS Project, B. Am. Meteorol. Soc., 89, 1147-1164, 2008.

Hsu N. C., Jeong M.-J., Bettenhausen, C., Sayer, A. M., Hansell, R., Seftor, C. S., Huang, J., and Tsay, S.-C.: Enhanced Deep Blue aerosol retrieval algorithm: The second generation, J. Geophys. Res.-Atmos., 118, 9296-9315, doi:10.1002/jgrd.50712, 2013.

Huijnen, V., Williams, J., van Weele, M., van Noije, T., Krol, M., Dentener, F., Segers, A., Houweling, S., Peters, W., de Laat, J., Boersma, F., Bergamaschi, P., van Velthoven, P., Le Sager, P., Eskes, H., Alkemade, F., Scheele, R., Nédélec, P., and Pätz, H.-W.: The global chemistry transport model TM5: description and evaluation of the tropospheric chemistry version 3.0, Geosci. Model Dev., 3, 445-473, doi:10.5194/gmd-3-445-2010, 2010.

Huijnen V., Wooster, M. J., Kaiser, J. W., Gaveau, D.L. A., Flemming, J., Parrington, M., Inness, A., Murdiyarso, D., Main, B., and van Weele, M.: Fire carbon emissions over maritime southeast Asia in 2015 largest since 1997, Sci. Rep., 6, 26886, doi:10.1038/srep26886, 2016.

Huneeus, N., Schulz, M., Balkanski, Y., Griesfeller, J., Prospero, J., Kinne, S., Bauer, S., Boucher, O., Chin, M., Dentener, F., Diehl, T., Easter, R., Fillmore, D., Ghan, S., Ginoux, P., Grini, A., Horowitz, L., Koch, D., Krol, M. C., Landing, W., Liu, X., Mahowald, N., Miller, R., Morcrette, J.-J., Myhre, G., Penner, J., Perlwitz, J., Stier, P., Takemura, T., and Zender, C. S.: Global dust model intercomparison in AeroCom phase I, Atmos. Chem. Phys., 11, 7781-7816, doi:10.5194/acp-11-7781-2011, 2011. 
Im, U., Bianconi, R., Solazzo, E., Kioutsioukis, I., Badia, A., Balzarini, A., Baró, R., Bellasio, R., Brunner, D., Chemel, C., Curci, G., Flemming, J., Forkel, R., Giordano, L., JiménezGuerrero, P., Hirtl, M., Hodzic, A., Honzak, L., Jorba, O., Knote, C., Kuenen, J. J. P., Makar, P. A., Manders-Groot, A., Neal, L., Pérez, J. L., Pirovano, G., Pouliot, G., San Jose, R., Savage, N., Schroder, W., Sokhi, R.S., Syrakov, D., Torian, A., Tuccella, P., Werhahn, J., Wolke, R., Yahya, K., Zabkar, R., Zhang, Y., Zhang, J., Hogrefe, C., and Galmarini, S.: Evaluation of operational on-line-coupled regional air quality models over Europe and North America in the context of AQMEII phase 2, Part I: Ozone, Atmos. Environ., 115, 404-420, doi:10.1016/j.atmosenv.2014.09.042, 2015.

Inness, A., Baier, F., Benedetti, A., Bouarar, I., Chabrillat, S., Clark, H., Clerbaux, C., Coheur, P., Engelen, R. J., Errera, Q., Flemming, J., George, M., Granier, C., Hadji-Lazaro, J., Huijnen, V., Hurtmans, D., Jones, L., Kaiser, J. W., Kapsomenakis, J., Lefever, K., Leitão, J., Razinger, M., Richter, A., Schultz, M. G., Simmons, A. J., Suttie, M., Stein, O., Thépaut, J.-N., Thouret, V., Vrekoussis, M., Zerefos, C., and the MACC team: The MACC reanalysis: an $8 \mathrm{yr}$ data set of atmospheric composition, Atmos. Chem. Phys., 13, 4073-4109, doi:10.5194/acp-13-4073-2013, 2013.

Inness, A., Blechschmidt, A.-M., Bouarar, I., Chabrillat, S., Crepulja, M., Engelen, R. J., Eskes, H., Flemming, J., Gaudel, A., Hendrick, F., Huijnen, V., Jones, L., Kapsomenakis, J., Katragkou, E., Keppens, A., Langerock, B., de Mazière, M., Melas, D., Parrington, M., Peuch, V. H., Razinger, M., Richter, A., Schultz, M. G., Suttie, M., Thouret, V., Vrekoussis, M., Wagner, A., and Zerefos, C.: Data assimilation of satellite retrieved ozone, carbon monoxide and nitrogen dioxide with ECMWF's Composition-IFS, Atmos. Chem. Phys., 15, 52755303, doi:10.5194/acp-15-5275-2015, 2015.

Jacob, D. J. H., Liu, C., Mari, and Yantosca, R. M.: Harvard wet deposition scheme for GMI, Harvard University Atmospheric Chemistry Modeling Group, in review, March 2000.

Jung, T., Palmer, T. N., Rodwell, M. J., and Serrar, S.: Diagnosing forecast error using relaxation experiments, ECMWF Newsletter 82, ECMWF, Shinfield Park, Reading, Berkshire RG2 9AX, UK, 2008.

Kaiser, J. W., Heil, A., Andreae, M. O., Benedetti, A., Chubarova, N., Jones, L., Morcrette, J.-J., Razinger, M., Schultz, M. G., Suttie, M., and van der Werf, G. R.: Biomass burning emissions estimated with a global fire assimilation system based on observed fire radiative power, Biogeosciences, 9, 527-554, doi:10.5194/bg-9-527-2012, 2012.

Katragkou, E., Zanis, P., Tsikerdekis, A., Kapsomenakis, J., Melas, D., Eskes, H., Flemming, J., Huijnen, V., Inness, A., Schultz, M. G., Stein, O., and Zerefos, C. S.: Evaluation of near-surface ozone over Europe from the MACC reanalysis, Geosci. Model Dev., 8, 2299-2314, doi:10.5194/gmd-8-2299-2015, 2015.

Kinne, S., Schulz, M., Textor, C., Guibert, S., Balkanski, Y., Bauer, S. E., Berntsen, T., Berglen, T. F., Boucher, O., Chin, M., Collins, W., Dentener, F., Diehl, T., Easter, R., Feichter, J., Fillmore, D., Ghan, S., Ginoux, P., Gong, S., Grini, A., Hendricks, J., Herzog, M., Horowitz, L., Isaksen, I., Iversen, T., Kirkevåg, A., Kloster, S., Koch, D., Kristjansson, J. E., Krol, M., Lauer, A., Lamarque, J. F., Lesins, G., Liu, X., Lohmann, U., Montanaro, V., Myhre, G., Penner, J., Pitari, G., Reddy, S., Seland, O., Stier, P., Take- mura, T., and Tie, X.: An AeroCom initial assessment - optical properties in aerosol component modules of global models, Atmos. Chem. Phys., 6, 1815-1834, doi:10.5194/acp-6-1815-2006, 2006.

Kinnison, D. E., Brasseur, G. P., Walters, S., Garcia, R. R.,. Marsh, D. R, Sassi, F., Harvey, V. L., Randall, C. E., Emmons, L., Lamarque, J. F., Hess, P., Orlando, J. J., Tie, X. X., Randel, W., Pan, L. L., Gettelman, A., Granier, C., Diehl, T., Niemeier, U., and Simmons, A. J.: Sensitivity of Chemical Tracers to Meteorological Parameters in the MOZART-3 Chemical Transport Model, J. Geophys. Res, 112, D03303, doi:10.1029/2008JD010739, 2007.

Komhyr, W. D., Barnes, R. A., Borthers, G. B., Lathrop, J. A., Kerr, J. B., and Opperman, D. P.: Electrochemical concentration cell ozonesonde performance evaluation during STOIC 1989, J. Geophys. Res., 100, 9231-9244, 1995.

Lamarque, J.-F., Shindell, D. T., Josse, B., Young, P. J., Cionni, I., Eyring, V., Bergmann, D., Cameron-Smith, P., Collins, W. J., Doherty, R., Dalsoren, S., Faluvegi, G., Folberth, G., Ghan, S. J., Horowitz, L. W., Lee, Y. H., MacKenzie, I. A., Nagashima, T., Naik, V., Plummer, D., Righi, M., Rumbold, S. T., Schulz, M., Skeie, R. B., Stevenson, D. S., Strode, S., Sudo, K., Szopa, S., Voulgarakis, A., and Zeng, G.: The Atmospheric Chemistry and Climate Model Intercomparison Project (ACCMIP): overview and description of models, simulations and climate diagnostics, Geosci. Model Dev., 6, 179-206, doi:10.5194/gmd-6-179-2013, 2013.

Lefever, K., van der A, R., Baier, F., Christophe, Y., Errera, Q., Eskes, H., Flemming, J., Inness, A., Jones, L., Lambert, J.C., Langerock, B., Schultz, M. G., Stein, O., Wagner, A., and Chabrillat, S.: Copernicus stratospheric ozone service, 20092012: validation, system intercomparison and roles of input data sets, Atmos. Chem. Phys., 15, 2269-2293, doi:10.5194/acp-152269-2015, 2015.

Levelt, P. F., van den Oord, G. H. J., Dobber, M. R., Malkki, A., Visser, H., de Vries, J., Stammes, P., Lundell, J. O. V., and Saari, H.: The ozone monitoring instrument, IEEE T. Geosci. Remote, 44, 1093-1101, 2006.

Levy, R. C., Remer, L. A., Kleidman, R. G., Mattoo, S., Ichoku, C., Kahn, R., and Eck, T. F.: Global evaluation of the Collection 5 MODIS dark-target aerosol products over land, Atmos. Chem. Phys., 10, 10399-10420, doi:10.5194/acp-10-10399-2010, 2010.

Liu, X., Bhartia, P. K., Chance, K., Spurr, R. J. D., and Kurosu, T. P.: Ozone profile retrievals from the Ozone Monitoring Instrument, Atmos. Chem. Phys., 10, 2521-2537, doi:10.5194/acp-10-25212010, 2010.

Manney, G., Santee, M. L., Rex, M., Livesey, N. J., Pitts, M. C., Veefkind, P., Nash, R. R., Wohltmann, I., Lehmann, R., Froidevaux, L., Poole, L. R., Schoeberl, M. R., Haffner, D. P., Davies, J., Dorokhov, V., Gernandt, H., Johnson, B., Kivi, R., Kyr o, E., Larsen, N., Levelt, P. F., Makshtas, A., McElroy, C. T., Nakajima, H., Parrondo, M. C., Tarasick, D.W., von der Gathen, P.,Walker, P. K. A., and Zinoviev, N. S.: Unprecedented Arctic ozone loss in 2011, Arctic winter 2010/2011 at the brink of an ozone hole, Nature, 478, 469-475, doi:10.1038/nature10556, 2011.

Marenco, A., Thouret, V., Nìedìelec, P., Smit, H. G., Helten, M., Kley, D., Karcher, F., Simon, P., Law, K., Pyle, J., Poschmann, G., Von Wrede, R., Hume, C., and Cook, T.: Measurement of ozone and water vapour by Airbus in-service air-craft: The 
MOZAIC airborne programme, an overview, J. Geophys. Res., 103, 25631-25642, 1998.

McNally, A. P., Watts, P. D., Smith, J. A., Engelen, R. J., Kelly, G. A., Thépaut, J.-N., and Matricardi, M.: The assimilation of AIRS radiance data at ECMWF, Q. J. Roy. Meteor. Soc., 132, 935-957, 2006.

Meijer, E. W., van Velthoven, P. F. J., Brunner, D. W., Huntrieser, H., and Kelder, H.: Improvement and evaluation of the parameterization of nitrogen oxide production by lightning, Phys. Chem. Earth Pt. C, 26, 577-583, 2001.

Miyazaki, K., Eskes, H. J., and Sudo, K.: A tropospheric chemistry reanalysis for the years 2005-2012 based on an assimilation of OMI, MLS, TES, and MOPITT satellite data, Atmos. Chem. Phys., 15, 8315-8348, doi:10.5194/acp-15-8315-2015, 2015.

Monks, P. S., Archibald, A. T., Colette, A., Cooper, O., Coyle, M., Derwent, R., Fowler, D., Granier, C., Law, K. S., Mills, G. E., Stevenson, D. S., Tarasova, O., Thouret, V., von Schneidemesser, E., Sommariva, R., Wild, O., and Williams, M. L.: Tropospheric ozone and its precursors from the urban to the global scale from air quality to short-lived climate forcer, Atmos. Chem. Phys., 15, 8889-8973, doi:10.5194/acp-15-8889-2015, 2015.

Morcrette, J.-J., Boucher, O., Jones, L., Salmond, D., Bechtold, P., Beljaars, A., Benedetti, A., Bonet, A., Kaiser, J. W., Razinger, M., Schulz, M., Serrar, S., Simmons, A. J., Sofiev, M., Suttie, M., Tompkins, A. M., and Untch, A.: Aerosol analysis and forecast in the ECMWF Integrated Forecast System, Part I: Forward modelling, J. Geophys. Res., 114, D06206, doi:10.1029/2008JD011235, 2009.

Morcrette, J. J., Benedetti, A., Jones, L., Kaiser, J. W., Razinger, M., and Suttie, M.: Prognostic Aerosols in the ECMWF IFS: MACC vs. GEMS Aerosols, ECMWF Technical Memorandum, 659, 32 pp., 2011.

Munro, R., Siddans, R., Reburn, W. J., and Kerridge, B. J.: Direct measurements of tropospheric ozone distributions from space, Nature, 392, 168-171, 1998.

Munro, R., Eisinger, M., Anderson, C., Callies, J., Corpaccioli, E., Lang, R., Lefebvre, A., Livschitz, Y., and Albinana, A. P.: GOME-2 on MetOp, Proc. of The 2006 EUMETSAT Meteorological Satellite Conference, Helsinki, Finland, 2006.

Nedelec, P., Cammas, J.-P., Thouret, V., Athier, G., Cousin, J.-M., Legrand, C., Abonnel, C., Lecoeur, F., Cayez, G., and Marizy, C.: An improved infrared carbon monoxide analyser for routine measurements aboard commercial Airbus aircraft: technical validation and first scientific results of the MOZAIC III programme, Atmos. Chem. Phys., 3, 1551-1564, doi:10.5194/acp-3-15512003, 2003.

Novelli, P. C. and Masarie, K. A.: Atmospheric Carbon Monoxide Dry Air Mole Fractions from the NOAA ESRL Carbon Cycle Cooperative Global Air Sampling Network, 1988-2012, Version: 8 August 2013, ftp://aftp.cmdl.noaa.gov/data/trace_gases/ co/flask/surface/ (last access: 6 May 2016), 2013.

Novelli, P. C., Masarie, K. A., Lang, P. M., Hall, B. D., Myers, R. C., and Elkins, J. W.: Reanalysis of tropospheric CO trends: effects of the 1997-1998 wildfires, J. Geophys. Res., 108, 4464, doi:10.1029/2002JD003031, 2003.

Olivier, J., Peters, J., Granier, C., Petron, G., Muller, J. F., and Wallens, S.: Present and future surface emissions of atmospheric compounds, POET report \#2, EU project EVK2-1999-00011, 2003.
Onogi, K., Tsutsui, J., Koide, H., Sakamoto, M., Kobayashi, S., Hatsushika, H., Matsumoto, T., Yamazaki, N., Kamahori, H., Takahashi, K., Kadokura, S., Wada, K., Kato, K., Oyama, R., Ose, T., Mannoji, N., and Taira, R.: The JRA-25 Reanalysis, Q. J. Roy. Meteor. Soc., 85, 369-432, 2007.

Reddy, M. S., Boucher, O., Bellouin, N., Schulz, M., Balkanski, Y., Dufresne, J.-L., and Pham, M.: Estimates of global multicomponent aerosol optical depth and direct radiative perturbation in the Laboratoire de Météorologie Dynamique general circulation model, J. Geophys. Res., 110, D10S16, doi:10.1029/2004JD004757, 2005.

Remer, L. A., Kaufman, Y. J. M, Tanré, D., Mattoo, S., Chu, D. A. M, Martins, J. V., Li, R.-R., Ichoku, C., Levy, R. C., Kleidman, R. G., Eck, T. F., Vermote, E., and Holben, B. N.: The MODIS Aerosol Algorithm, Products, and Validation, J. Atmos. Sci., 62, 947-973, 2005.

Rienecker, M. M., Suarez, M. J., Gelaro, R., Todling, R., Bacmeister, J., Liu, E., Bosilovich, M. G., Schubert, S. D., Takacs, L., Kim, G.- K., Bloom, S., Chen, J., Collins, D., Conaty, A., da Silva, A., Gu, W., Joiner, J., Koster, R. D., Lucchesi, R., Molod, A. M., Owens, T., Pawson, S., Pegion, P., Redder, C. R., Reichle, R., Robertson, F. R., Ruddick, A. G., Sienkiewicz, M., and Woollen, J.: MERRA - NASA's ModernEra Retrospective, Anal. Res. Appl., J. Climate, 24, 3624-3648, doi:10.1175/JCLID-11-00015.1, 2011.

Saha, S., Moorthi, S., Pan, H. L., Wu, X., Wang, J., Nadiga, S., Tripp, P., Kistler, R., Woollen, J., Behringer, D., Liu, H., Stokes, D., Grumbine, R., Gayno, G., Hou, Y. T., Chuang, H. Y., Juang, H. M. H., Sela, J., Iredell, M., Treadon, R., Kleist, D., Van Delst, P., Keyser, D., Derber, J., Ek, M., Meng, J., Wei, H., Yang, R., Lord, S., Van Den Dool, H., Kumar, A., Wang, W., Long, C., Chelliah, M., Xue, Y., Huang, B., Schemm, J. K., Ebisuzaki, W., Lin, R., Xie, P., Chen, M., Zhou, S., Higgins, W., Zou, C. Z., Liu, Q., Chen, Y., Han, Y., Cucurull, L., Reynolds, R. W., Rutledge, G., and Goldberg, M.: The NCEP climate forecast system reanalysis, B. Am. Meteorol. Soc., 91, 1015-1057, 2010.

Schere, K., Flemming, J., Vautard, R., Chemel, C., Colette, A., Hogrefe, C., Bessagnet, B., Meleux, F., Mathur, R., Roselle, S., Hu, R.-M., Sokhi, R. S., Rao, S. T., and Galmarini, S.: Trace gas/aerosol boundary concentrations and their impacts on continental-scale AQMEII modeling domains, Atmos. Environ., 53, 38-50, doi:10.1016/j.atmosenv.2011.09.043, 2012.

Schutgens, N. A. J., Nakata, M., and Nakajima, T.: Estimating aerosol emissions by assimilating remote sensing observations into a Global transport model, Remote Sens., 4, 3528-3543, 2012.

Shi, Y., Zhang, J., Reid, J. S., Holben, B., Hyer, E. J., and Curtis, C.: An analysis of the collection 5 MODIS over-ocean aerosol optical depth product for its implication in aerosol assimilation, Atmos. Chem. Phys., 11, 557-565, doi:10.5194/acp-11-557-2011, 2011.

Shindell, D. T., Faluvegi, G., Stevenson, D. S., Krol, M. C., Emmons, L. K., Lamarque, J.-F., Pétron, G., Dentener, F. J., Ellingsen, K., Schultz, M. G., Wild, O., Amann, M., Atherton, C. S., Bergmann, D. J., Bey, I., Butler, T., Cofala, J., Collins, W. J., Derwent, R. G., Doherty, R. M., Drevet, J., Eskes, H. J., Fiore, A. M., Gauss, M., Hauglustaine, D. A., Horowitz, L. W., Isaksen, I. S. A., Lawrence, M. G., Montanaro, V., Müller, J.-F., Pitari, G., Prather, M. J., Pyle, J. A., Rast, S., Rodriguez, J. M., 
Sanderson, M. G., Savage, N. H., Strahan, S. E., Sudo, K., Szopa, S., Unger, N., van Noije, T. P. C., and Zeng, G.: Multi-model simulations of carbon monoxide: Comparison with observations and projected near-future changes, J. Geophys. Res., 111, D19306, doi:10.1029/2006JD007100, 2006.

Sindelarova, K., Granier, C., Bouarar, I., Guenther, A., Tilmes, S., Stavrakou, T., Müller, J.-F., Kuhn, U., Stefani, P., and Knorr, W.: Global data set of biogenic VOC emissions calculated by the MEGAN model over the last 30 years, Atmos. Chem. Phys., 14, 9317-9341, doi:10.5194/acp-14-9317-2014, 2014.

Spada, M., Jorba, O., Pérez García-Pando, C., Janjic, Z., and Baldasano, J. M.: Modeling and evaluation of the global sea-salt aerosol distribution: sensitivity to size-resolved and sea-surface temperature dependent emission schemes, Atmos. Chem. Phys., 13, 11735-11755, doi:10.5194/acp-13-11735-2013, 2013.

Stein, O., Schultz, M. G., Bouarar, I., Clark, H., Huijnen, V., Gaudel, A., George, M., and Clerbaux, C.: On the wintertime low bias of Northern Hemisphere carbon monoxide in global model studies, Atmos. Chem. Phys., 14, 9295-9316, doi:10.5194/acp14-9295-2014, 2014

Steinbrecht, W., Shwartz, R., and Claude, H.: New pump correction for the Brewer-Mast ozonesonde: Determination from experiment and instrument intercomparisons, J. Atmos. Ocean. Tech., 15, 144-156, 1998.

Tegtmeier, S., Hegglin, M. I., Anderson, J., Bourassa, A., Brohede, S., Degenstein, D., Froide- vaux, L., Fuller, R., Funke, B., Gille, J., Jones, A., Kasai, Y., Krüger, K., Kyrölä, E., Lingen- felser, G., Lumpe, J., Nardi, B., Neu, J., Pendlebury, D., Remsberg, E., Rozanov, A., Smith, L., Toohey, M., Urban, J., von Clarmann, T., Walker, K. A., and Wang, R. H. J.: SPARC Data Initiative: a comparison of ozone climatologies from international satellite limb sounders, J. Geophys. Res., 118, 12229-12247, doi:10.1002/2013JD019877, 2013.

Textor, C., Schulz, M., Guibert, S., Kinne, S., Balkanski, Y., Bauer, S., Berntsen, T., Berglen, T., Boucher, O., Chin, M., Dentener, F., Diehl, T., Easter, R., Feichter, H., Fillmore, D., Ghan, S., Ginoux, P., Gong, S., Grini, A., Hendricks, J., Horowitz, L., Huang, P., Isaksen, I., Iversen, I., Kloster, S., Koch, D., Kirkevåg, A., Kristjansson, J. E., Krol, M., Lauer, A., Lamarque, J. F., Liu, X., Montanaro, V., Myhre, G., Penner, J., Pitari, G., Reddy, S., Seland, $\varnothing .$, Stier, P., Takemura, T., and Tie, X.: Analysis and quantification of the diversities of aerosol life cycles within AeroCom, Atmos. Chem. Phys., 6, 1777-1813, doi:10.5194/acp-6-1777-2006, 2006.

Uppala, S., Kallberg, P., Simmons, A. J., Andrae, U., Bechtold, V. D. C., Fiorino, M., Gibson, J. K., Haseler, J., Hernandez, A., Kelly, G. A., Li, X., Onogi, K., Saarinen, S., Sokka, N., Allan, R. P., Andersson, E., Arpe, K., Balmaseda, M. A., Beljaars, A. C. M., van de Berg, L., Bidlot, J., Bormann, N., Caires, S., Chevallier, F., Dethof, A., Dragosavac, M., Fisher, M., Fuentes, M., Hagemann, S., Holm, E., Hoskins, B. J., Isaksen, L., Janssen, P. A. E. M., Jenne, R., McNally, A. P., Mahfouf, J. F., Morcrette, J. J., Rayner, N. A., Saunders, R. W., Simon, P., Sterl, A., Trenberth, K. E., Untch, A., Vasiljevic, D., Viterbo, P., and Woollen, J.: The ERA-40 re-analysis, Q. J. Roy. Meteor. Soc., 131, 29613012, 2005.

van der A, R. J., Allaart, M. A. F., and Eskes, H. J.: Multi sensor reanalysis of total ozone, Atmos. Chem. Phys., 10, 11277-11294, doi:10.5194/acp-10-11277-2010, 2010. van der A, R. J., Allaart, M. A. F., and Eskes, H. J.: Extended and refined multi sensor reanalysis of total ozone for the period 19702012, Atmos. Meas. Tech., 8, 3021-3035, doi:10.5194/amt-83021-2015, 2015.

Verstraeten, W. W., Neu, J. L., Williams, J. E., Bowman, K. W., Worden, J. R., and Boersma, K. F.: Rapid increases in tropospheric ozone production and export from China, Nat. Geosci., 8, 690-695, doi:10.1038/ngeo2493, 2015.

von Clarmann, T., Glatthor, N., Grabowski, U., Höpfner, M., Kellmann, S., Kiefer, M., Linden, A., Mengistu Tsidu, G., Milz, M., Steck, T., Stiller, G. P., Wang, D. Y., Fischer, H., Funke, B., Gil-López, S., and López-Puertas, M.: Retrieval of temperature and tangent altitude pointing from limb emission spectra recorded from space by the Michelson Interferometer for Passive Atmospheric Sounding (MIPAS), J. Geophys. Res., 108, 4736, doi:10.1029/2003JD003602, 2003.

Wagner, A., Blechschmidt, A.-M., Bouarar, I., Brunke, E.-G., Clerbaux, C., Cupeiro, M., Cristofanelli, P., Eskes, H., Flemming, J., Flentje, H., George, M., Gilge, S., Hilboll, A., Inness, A., Kapsomenakis, J., Richter, A., Ries, L., Spangl, W., Stein, O., Weller, R., and Zerefos, C.: Evaluation of the MACC operational forecast system - potential and challenges of global near-realtime modelling with respect to reactive gases in the troposphere, Atmos. Chem. Phys., 15, 14005-14030, doi:10.5194/acp-1514005-2015, 2015.

Waters, J.W., Froidevaux, L., Harwood, R. S., Jarnot, R. F., Pickett, H. M., Read, W. G., Siegel, P. H., Cofield, R. E., Filipiak, M. J., Flower, D. A., Holden, J. R., Lau, G. K., Livesey, N. J., Manney, G. L., Pumphrey, H. C., Santee, M. L., Wu, D. L., Cuddy, D. T., Lay, R. R., Loo, M. S., Perun, V. S., Schwartz, M. J., Stek, P. C., Thurstans, R. P., Boyles, M. A., Chandra, K. M., Chavez, M. C., Chen, G. S., Chudasama, B. V., Dodge, R., Fuller, R. A., Girard, M. A., Jiang, J. H., Jiang, Y., Knosp, B. W., Labelle, R. C., Lam, J. C., Lee, A. K., Miller, D., Oswald, J. E., Patel, N. C., Pukala, D. M., Quintero, O., Scaff, D. M., Vansnyder, W., Tope, M. C., Wagner, P. A., and Walch, M. J.: The Earth Observing System Microwave Limb Sounder (EOS MLS) on theAura Satellite, IEEE T. Geosci. Remote, 44, 1075-1092, 2006.

Wesely, M. L.: Parameterization of Surface Resistances to Gaseous Dry Deposition in Regional-Scale Numerical Models, Atmos. Environ., 23, 1293-1304, 1989.

Worden, H. M., Deeter, M. N., Frankenberg, C., George, M., Nichitiu, F., Worden, J., Aben, I., Bowman, K. W., Clerbaux, C., Coheur, P. F., de Laat, A. T. J., Detweiler, R., Drummond, J. R., Edwards, D. P., Gille, J. C., Hurtmans, D., Luo, M., MartínezAlonso, S., Massie, S., Pfister, G., and Warner, J. X.: Decadal record of satellite carbon monoxide observations, Atmos. Chem. Phys., 13, 837-850, doi:10.5194/acp-13-837-2013, 2013.

Yarwood, G., Rao, S., Yocke, M., and Whitten, G.: Updates to the carbon bond chemical mechanism: CB05. Final report to the US EPA, EPA Report Number: RT-0400675, available at: http://www.camx.com (last access: 1 July 2014), 2005. 